\title{
Costs of Lithium-Ion Batteries for Vehicles
}
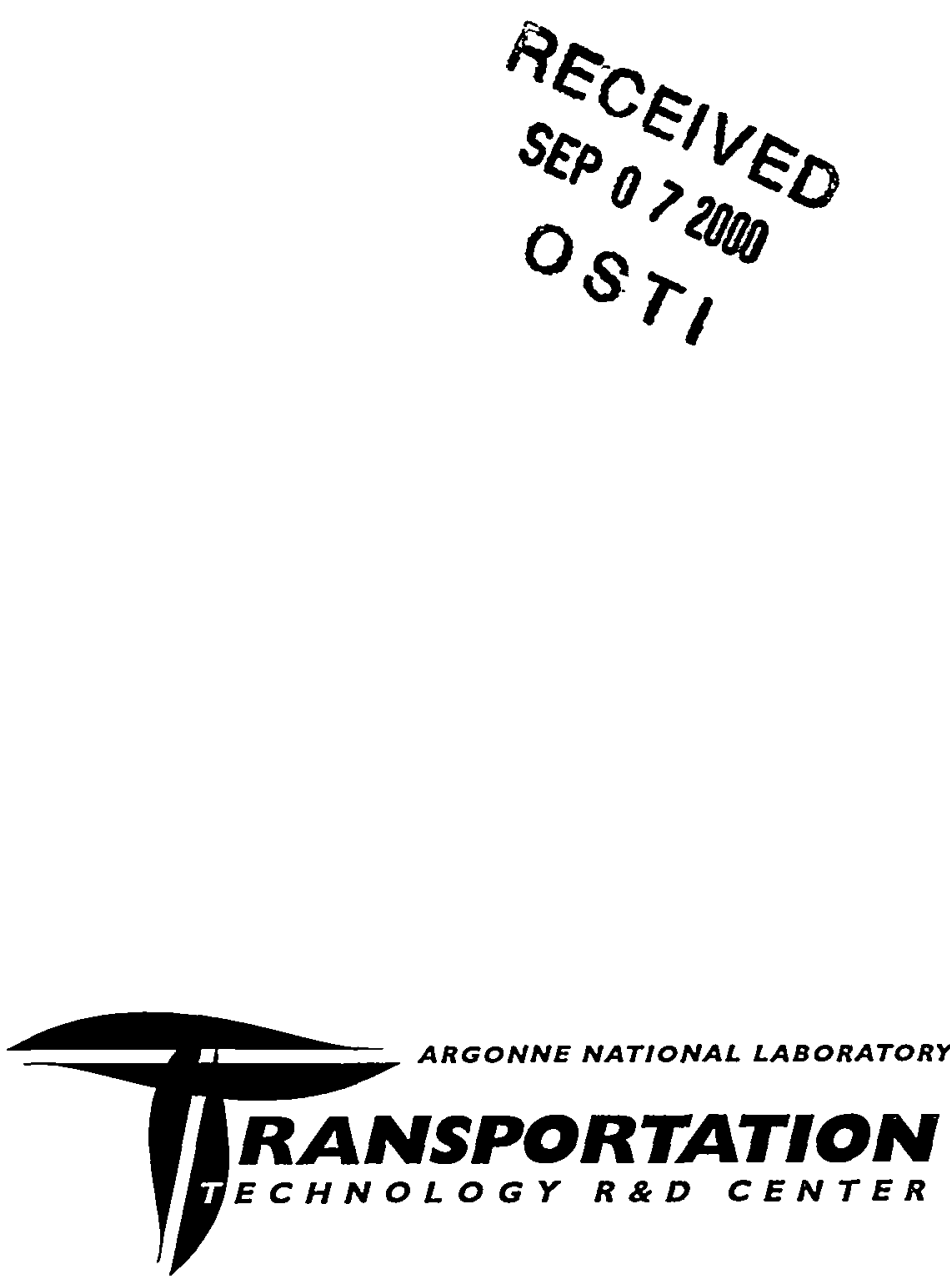

Center for Transportation Research Argonne National Laboratory

Operated by The University of Chicago, under Contract W-31-109-Eng-38, for the United States Department of Energy 


\section{Argonne National Laboratory}

Argonne National Laboratory, with facilities in the states of Illinois and Idaho, is owned by the United States Government, and operated by the University of Chicago under the provisions of a contract with the Department of Energy.

This technical report is a product of Argonne's Energy Systems Division.

For information on the division's scientific and engineering activities, contact:

Director, Energy Systems Division

Argonne National Laboratory

Argonne, Illinois 60439-4815

Telephone (630) 252-3724

Publishing support services were provided by Argonne's Information and Publishing Division (for more information, see IPD's home page: http://www.ipd.anl.gov/).

\section{Disclaimer}

This report was prepared as an account of work sponsored by an agency of the United States Government. Neither the United States Government nor any agency thereof, nor The University of Chicago, nor any of their employees or officers, makes any warranty, express or implied, or assumes any legal liability or responsibility for the accuracy, completeness, or usefulness of any information, apparatus, product, or process disclosed, or represents that its use would not infringe privately owned rights. Reference herein to any specific commercial product, process, or service by trade name, trademark, manufacturer, or otherwise does not necessarily constitute or imply its endorsement, recommendation, or favoring by the United States Government or any agency thereof. The views and opinions of document authors expressed herein do not necessarily state or reflect those of the United States Government or any agency thereof, Argonne National Laboratory, or The University of Chicago.

Available electronically at http://www.doe.gov/bridge Avallable for a processing fee to U.S. Department of Energy and its contractors, in paper, from:

U.S. Department of Energy

Office of Scientific and Technical Information

P.O. Box 62

Oak Ridge, TN 37831-0062

phone: (865) 576-8401

fax: (865) 576-5728

email: reports@adonis.osti.gov 


\section{DISCLAIMER}

Portions of this document may be illegible in electronic image products. Images are produced from the best available original document. 


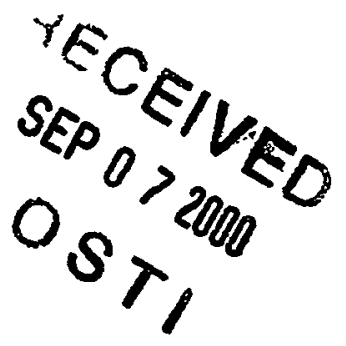

ANL/ESD-42

\section{Costs of Lithium-Ion Batteries for Vehicles}

by Linda Gaines and Roy Cuenca

Center for Transportation Research, Energy Systems Division,

Argonne National Laboratory, 9700 South Cass Avenue, Argonne, Illinois 60439

May 2000

Work Sponsored by United States Department of Energy

Assistant Secretary for Energy Efficiency and Renewable Energy

Office of Transportation Technologies 
This report is printed on recycled paper. 


\section{Preface}

Although recent studies by Argonne National Laboratory's Center for Transportation Research (CTR) have addressed energy-cycle impacts and first and life-cycle battery costs, taking into account cycle life, shelf life, power density, energy density, and cost, the lithium-ion (Li-ion) battery, recently adapted for use in electric vehicles (EVs) by Nissan, has not yet been addressed. There is a concern that a commitment to mass production of nickel-metal hydride (Ni-MH) batteries - the present technology leaders for EVs - could be a mistake if rapid improvements in other battery types were to make $\mathrm{Ni}-\mathrm{MH}$ batteries obsolete before the investment in their production facilities could be paid off. For proper investor evaluation, it is necessary to examine the potential for $\mathrm{Li}$-ion batteries to realize significantly lower costs.

This project was originally focused on Li-ion batteries for use in EVs or in hybrid vehicles with a considerable all-electric range, assuming use of electricity from the grid. However, consideration of high-power-density Li-ion batteries was included because of the large potential for power-assist hybrid vehicles, and the dual-mode hybrids were deemphasized because they are intermediate between EVs and power-assist hybrids. Lithium-polymer batteries and ultracapacitors were not examined.

Sources of information for this project have included published literature and news releases, leads developed from published sources, World Wide Web entries, United States Geological Survey commodity specialists, battery experts in Argonne's Chemical Technology Division, personal contacts from such groups as the Advanced Battery Readiness Ad Hoc Working Group, and battery and material manufacturers. Some of the desired information was difficult to obtain because the battery research is still under way. However, it was possible to obtain at least qualitative judgments concerning where critical cost factors arise and what the prospects are for dealing with them. 
$\Delta$ 


\section{Contents}

Preface $\ldots \ldots \ldots \ldots \ldots \ldots \ldots \ldots \ldots \ldots \ldots \ldots \ldots \ldots \ldots \ldots \ldots \ldots \ldots \ldots \ldots \ldots$, iii

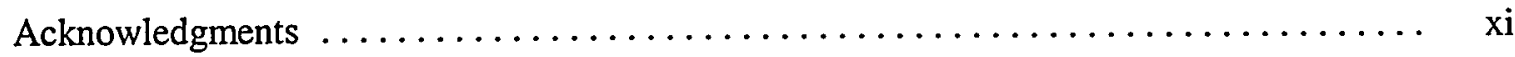

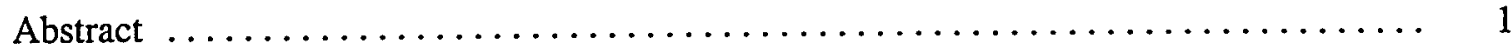

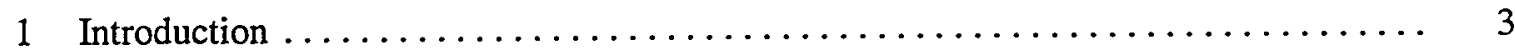

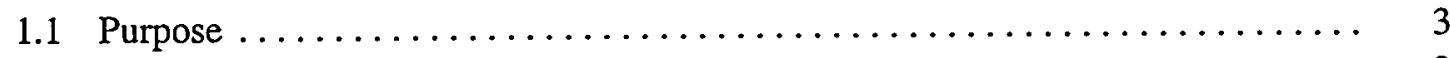

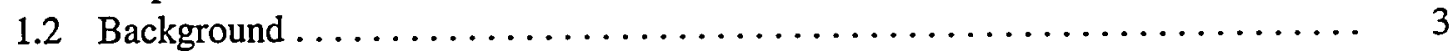

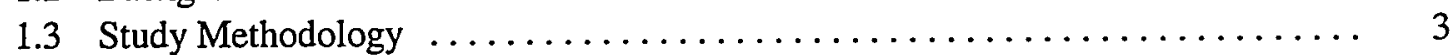

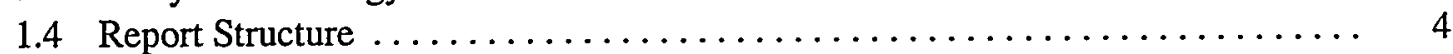

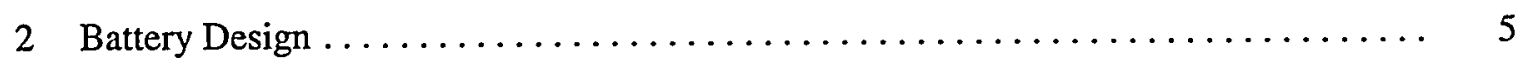

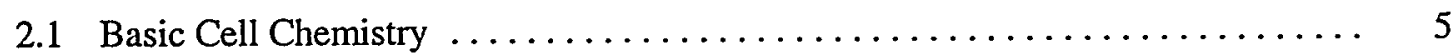

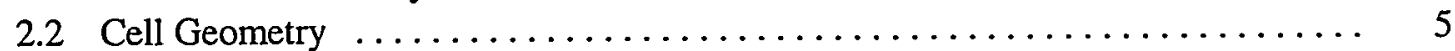

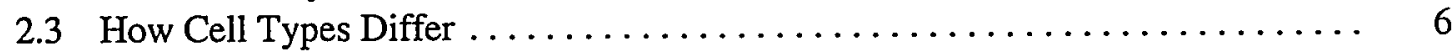

2.4 From Cells to Modules to Battery Packs $\ldots \ldots \ldots \ldots \ldots \ldots \ldots \ldots \ldots \ldots$

3 Cell Components $\ldots \ldots \ldots \ldots \ldots \ldots \ldots \ldots \ldots \ldots \ldots \ldots \ldots \ldots \ldots \ldots \ldots \ldots \ldots \ldots \ldots$

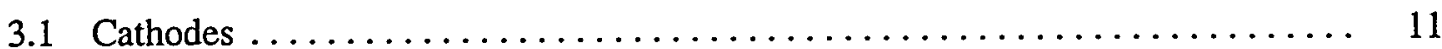

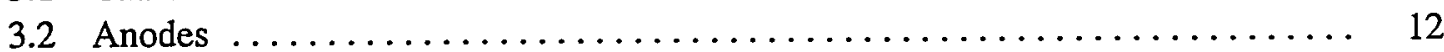

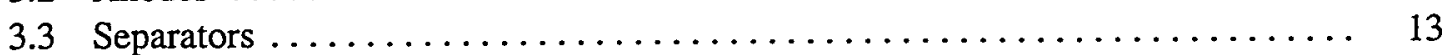

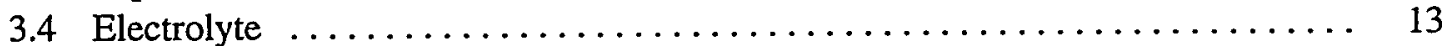

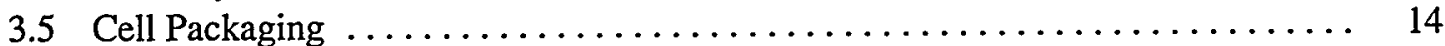

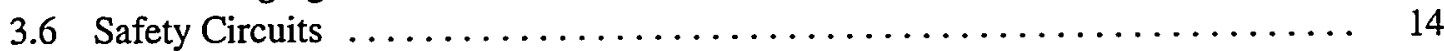

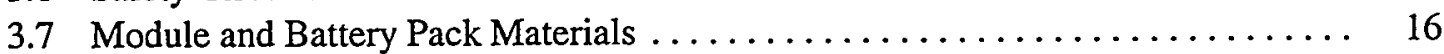

4 Materials and Production Processes $\ldots \ldots \ldots \ldots \ldots \ldots \ldots \ldots \ldots \ldots \ldots \ldots \ldots \ldots \ldots \ldots$

4.1 Raw Materials for Cathode Production $\ldots \ldots \ldots \ldots \ldots \ldots \ldots \ldots \ldots \ldots \ldots$

4.1.1 Cobalt ................................... 17

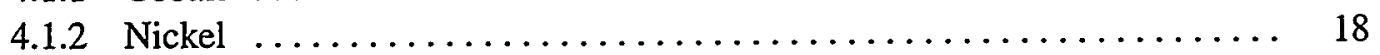

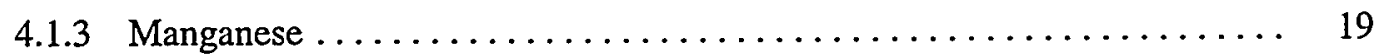

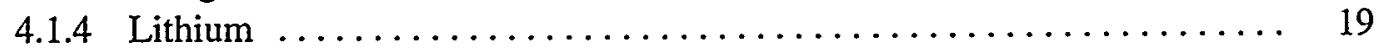

4.2 Cathode Active Material Production . . . . . . . . . . . . . . . . . 20

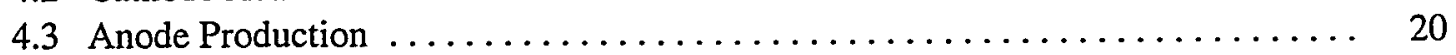




\section{Contents (Cont.)}

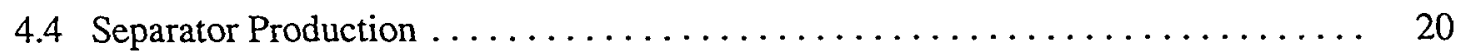

4.5 Battery Production Process $\ldots \ldots \ldots \ldots \ldots \ldots \ldots \ldots \ldots \ldots \ldots \ldots \ldots \ldots \ldots \ldots \ldots \ldots$

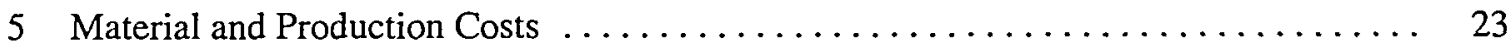

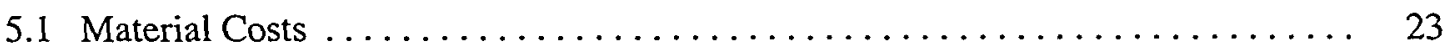

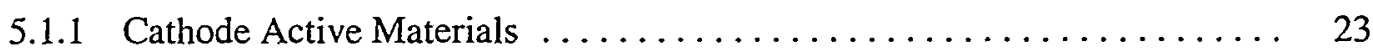

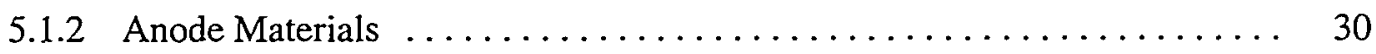

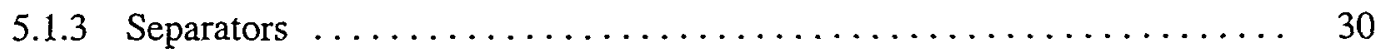

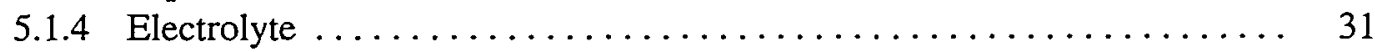

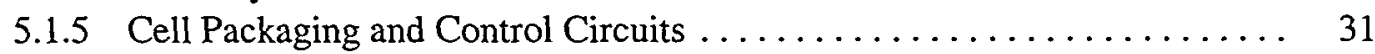

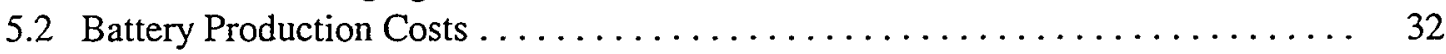

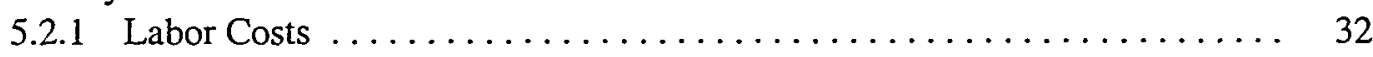

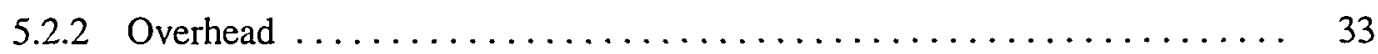

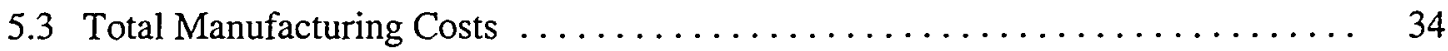

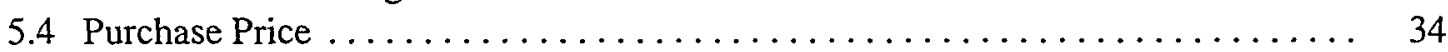

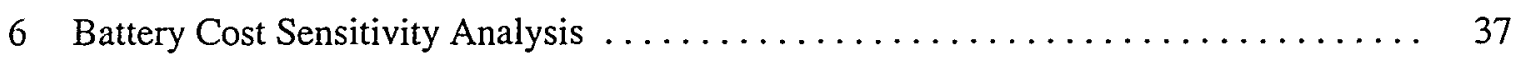

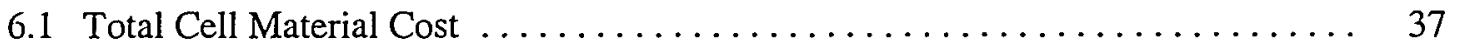

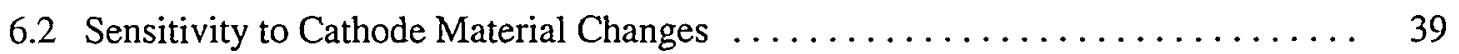

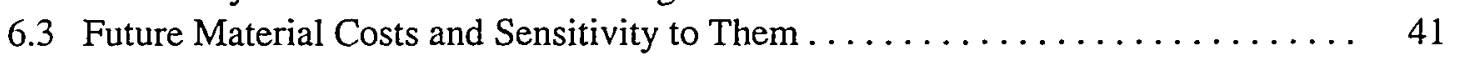

6.4 Total Sales Price for the Battery Pack $\ldots \ldots \ldots \ldots \ldots \ldots \ldots \ldots \ldots \ldots \ldots \ldots$

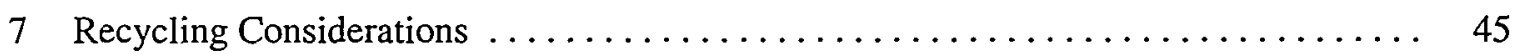

7.1 Current Status of Li-Ion Battery Recycling $\ldots \ldots \ldots \ldots \ldots \ldots \ldots \ldots \ldots$

7.2 Future Recycling Processes and Infrastructure $\ldots \ldots \ldots \ldots \ldots \ldots \ldots \ldots \ldots \ldots$

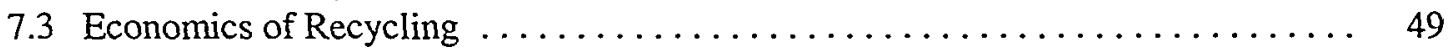

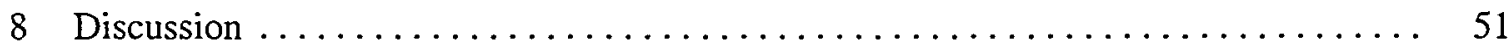

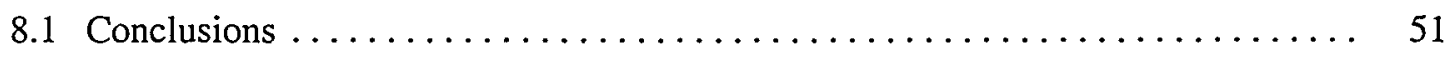

8.2 Japanese Dominance of the Li-Ion Battery Market ............... 51

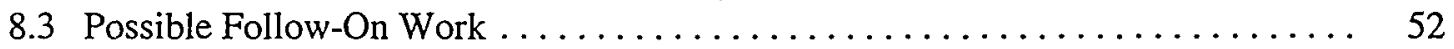

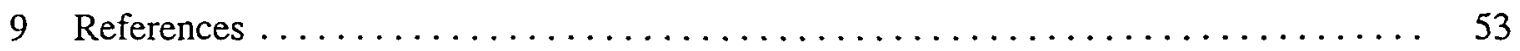




\section{Figures}

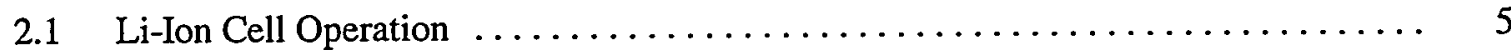

2.2 Cylindrical Cell Design .................................... 6

2.3 Module with Control Circuit $\ldots \ldots \ldots \ldots \ldots \ldots \ldots \ldots \ldots \ldots \ldots \ldots \ldots \ldots \ldots$

2.4 From Cell to Module to Battery Pack $\ldots \ldots \ldots \ldots \ldots \ldots \ldots \ldots \ldots \ldots \ldots \ldots$

2.5 Nissan Altra with Li-Ion Batteries $\ldots \ldots \ldots \ldots \ldots \ldots \ldots \ldots \ldots \ldots \ldots \ldots, 9$

2.6 SAFT 6-A.h High-Power Cell and Module $\ldots \ldots \ldots \ldots \ldots \ldots \ldots \ldots \ldots \ldots$

2.7 SAFT Conceptual Design for High-Power Battery . . . . . . . . . . . . . . . . 9

3.1 Current-Collector Foils $\ldots \ldots \ldots \ldots \ldots \ldots \ldots \ldots \ldots \ldots \ldots \ldots \ldots \ldots, 12$

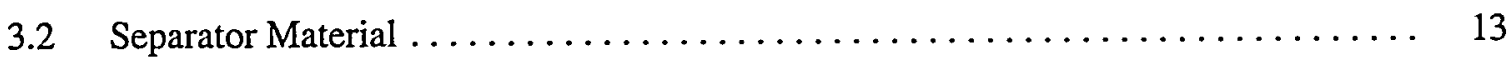

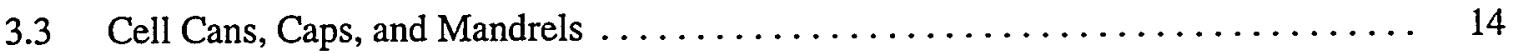

$4.1 \quad$ Winding Production $\ldots \ldots \ldots \ldots \ldots \ldots \ldots \ldots \ldots \ldots \ldots \ldots \ldots \ldots \ldots \ldots \ldots \ldots \ldots, 21$

$4.2 \quad$ Calendering Machine $\ldots \ldots \ldots \ldots \ldots \ldots \ldots \ldots \ldots \ldots \ldots \ldots \ldots \ldots \ldots \ldots \ldots \ldots, 21$

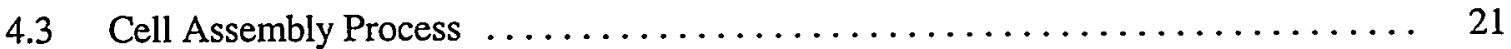

$4.4 \quad$ Automated Cell Assembly Line $\ldots \ldots \ldots \ldots \ldots \ldots \ldots \ldots \ldots \ldots \ldots \ldots .22$

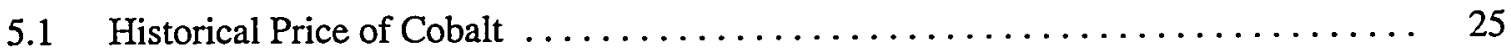

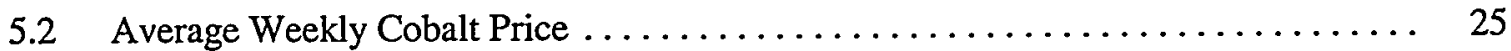

$5.3 \quad$ Historical Price of Nickel $\ldots \ldots \ldots \ldots \ldots \ldots \ldots \ldots \ldots \ldots \ldots \ldots, 26$

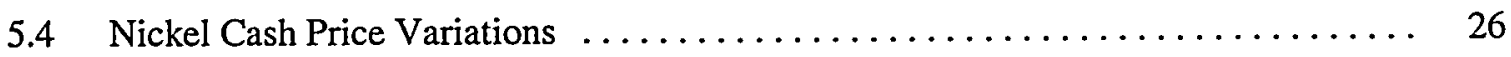

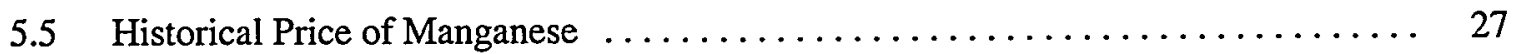

5.6 Historical Price of Lithium Carbonate $\ldots \ldots \ldots \ldots \ldots \ldots \ldots \ldots \ldots \ldots .28$

5.7 Cathode Active Material Price vs. Quantity $\ldots \ldots \ldots \ldots \ldots \ldots \ldots \ldots \ldots .29$

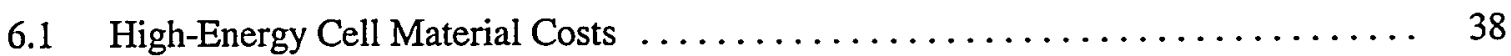




\section{Figures (Cont.)}

6.2 Sensitivity of Total Battery Material Cost to Cost of Cathode Material . . . . . . . 39

7.1 Sony Li-Ion Battery Recycling Concept $\ldots \ldots \ldots \ldots \ldots \ldots \ldots \ldots \ldots \ldots \ldots$

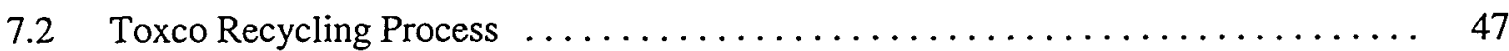

7.3 Toxco Cryogenic Freezing Process $\ldots \ldots \ldots \ldots \ldots \ldots \ldots \ldots \ldots \ldots \ldots \ldots \ldots$

7.4 Toxco Lithium Carbonate Recovery $\ldots \ldots \ldots \ldots \ldots \ldots \ldots \ldots \ldots \ldots \ldots \ldots \ldots \ldots$

\section{Tables}

2.1 Typical Li-Ion Cell Dimensions $\ldots \ldots \ldots \ldots \ldots \ldots \ldots \ldots \ldots \ldots \ldots \ldots \ldots \ldots$

2.2 Estimated Materials Content of Typical Li-Ion Cells $\ldots \ldots \ldots \ldots \ldots \ldots \ldots \ldots$

2.3 SAFT High-Power Module Characteristics $\ldots \ldots \ldots \ldots \ldots \ldots \ldots \ldots \ldots$

3.1 Cathode Material Energy Storage Capacities $\ldots \ldots \ldots \ldots \ldots \ldots \ldots \ldots \ldots \ldots \ldots$

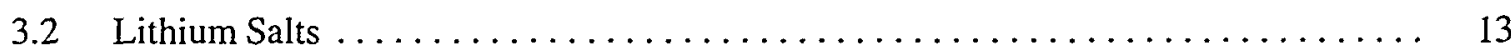

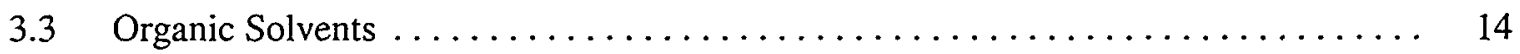

4.1 Comparative Li-Ion Cathode Material Data $\ldots \ldots \ldots \ldots \ldots \ldots \ldots \ldots \ldots \ldots$

5.1 Summary of Manufacturing Cost Components $\ldots \ldots \ldots \ldots \ldots \ldots \ldots \ldots \ldots \ldots \ldots$

5.2 Direct Operations Personnel for Cylindrical Cell Production $\ldots \ldots \ldots \ldots \ldots \ldots .33$

5.3 Rough Estimate of 18650 Cell Manufacturing Costs $\ldots \ldots \ldots \ldots \ldots \ldots \ldots \ldots$

6.1 Material Costs for 100-A·h High-Energy Cell and $10-\mathrm{A} \cdot \mathrm{h}$ High-Power Cell . . . . . 37

6.2 Cost Contributions for High-Power Cell $\ldots \ldots \ldots \ldots \ldots \ldots \ldots \ldots \ldots \ldots \ldots$

6.3 Current Cathode Material Prices $\ldots \ldots \ldots \ldots \ldots \ldots \ldots \ldots \ldots \ldots \ldots \ldots \ldots \ldots \ldots \ldots \ldots \ldots \ldots$

6.4 Optimistic Future Cell Material Costs for 100-A.h High-Energy Cell and 10 -A.h High-Power Cell $\ldots \ldots \ldots \ldots \ldots \ldots \ldots \ldots \ldots \ldots \ldots \ldots \ldots \ldots \ldots \ldots \ldots \ldots$

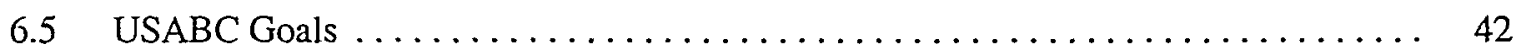




\section{Tables (Cont.)}

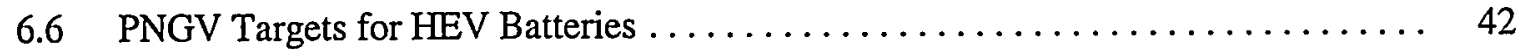

6.7 Materials Costs on Different Bases $\ldots \ldots \ldots \ldots \ldots \ldots \ldots \ldots \ldots \ldots \ldots \ldots \ldots$

6.8 Estimated Li-Ion Battery Pack Prices $\ldots \ldots \ldots \ldots \ldots \ldots \ldots \ldots \ldots \ldots \ldots \ldots \ldots \ldots \ldots \ldots$ 


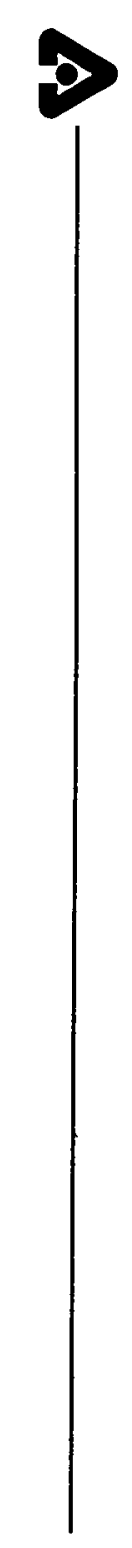




\section{Acknowledgments}

The authors would like to thank the many people who helped and supported us during the preparation of this report. We received considerable tutorial information from other Argonne staff members, especially Khalil Amine and Donald Vissers in the Chemical Technology Division. Kim Shedd, Peter Kuck, Joyce Ober, and Thomas Jones, the relevant commodity specialists at the United States Geological Survey, provided invaluable details and data, as well as technical review. Harold Haskins at Ford also provided a very thoughtful review. Numerous other industry experts provided data, insights, and technical review. Our sponsors, Philip Patterson, Kenneth Heitner, and Raymond Sutula of the Energy Management Team at the United States Department of Energy, Office of Transportation Technologies, Office of Advanced Automotive Technologies, provided funding, encouragement, and useful suggestions. 
$\Delta-$ 


\section{Abstract}

One of the most promising battery types under development for use in both pure electric and hybrid electric vehicles is the lithium-ion battery. These batteries are well on their way to meeting the challenging technical goals that have been set for vehicle batteries. However, they are still far from achieving the current cost goals. The Center for Transportation Research at Argonne National Laboratory undertook a project for the United States Department of Energy to estimate the costs of lithium-ion batteries and to project how these costs might change over time, with the aid of research and development. Cost reductions could be expected as the result of material substitution, economies of scale in production, design improvements, and/or development of new material supplies. The most significant contributions to costs are found to be associated with battery materials. For the pure electric vehicle, the battery cost exceeds the cost goal of the United States Advanced Battery .Consortium by about $\$ 3,500$, which is certainly enough to significantly affect the marketability of the vehicle. For the hybrid, however, the total cost of the battery is much smaller, exceeding the cost goal of the Partnership for a New Generation of Vehicles by only about $\$ 800$, perhaps not enough to deter a potential buyer from purchasing the power-assist hybrid. 
$\Delta$ 


\section{Section 1 \\ Introduction}

\subsection{Purpose}

Because both pure electric vehicles and hybrid vehicles offer the prospect of reduced emissions and decreased reliance on imported petroleum, these vehicle types have attracted great interest from environmentalists and other groups over the past 20 years or so. However, the promise of these vehicles has not yet been fulfilled. Technical performance goals are within reach, but the costs remain too high for these vehicles to gain mass-market acceptance. The biggest remaining challenge is to bring the incremental electric vehicle (EV) cost down, and this means reducing the dominant component of the incremental cost: the cost of the battery.

One of the most promising new battery types is the lithium-ion battery, in part because of its high energy and power densities, and also because it has the potential to last the lifetime of the car, a major economic advantage over most other batteries. It is the purpose of this report to provide current and projected cost estimates for lithium-ion batteries, as a function of materials used and battery type. The areas where potentially significant cost reductions are possible are identified, and optimistic projections of high-volume costs are compared with the cost goals set by the United States Advanced Battery Consortium (USABC) for batteries for EVs and with those set by the Partnership for a New Generation of Vehicles (PNGV) for batteries for hybrid electric vehicles (HEVs).

\subsection{Background}

Lithium-ion (Li-ion) batteries are currently in large-scale commercial production for use in such consumer electronic products as laptop computers and portable telephones. Among the major producers are Sony, Sanyo, Varta, and SAFT. Most Li-ion production is in Japan, but Polystor is now producing small cells in California. The technology used to produce these small consumer cells is essentially transferable to production of the larger cell sizes that would be put together into battery packs for EVs and HEVs. However, the cost of the small cells is far too high for such batteries to be used economically in mass-market vehicles. Therefore, to improve their competitive position, and also with a view to potential long-term development of the vehicle market, considerable research and development (R\&D) work has been devoted to lowering the costs of Li-ion batteries. Much of the effort has focused on reducing the extremely high cathode costs. However, as cathode costs are brought down, efforts to reduce other cost components are also appropriate.

\subsection{Study Methodology}

This study extends previous Argonne National Laboratory (ANL) cost analyses to Li-ion batteries. It builds on extensive R\&D work supported by the U.S. Department of Energy (DOE) through USABC, as well as on the National Research Council's (NRC's) PNGV review and on published work by Kalhammer et al. (1995) and others. The tasks were conceived as described below. 
Task 1: Characterize Materials

Characterize the materials usage for $\mathrm{Li}$-ion batteries and determine how the material mix varies with cell type. Identify the key materials and characterize the different materials under consideration. In particular, the choice of transition metal in the cathode is important. Use of nickel (Ni) or manganese $(\mathrm{Mn})$ instead of cobalt $(\mathrm{Co})$ will reduce the cost, but it may also affect performance. Such trade-offs must be examined.

\section{Task 2: Characterize Current Material and Battery Production}

Determine the current production volume, methods, and costs for the candidate materials and assembled batteries. Identify those cases where high cost could impede battery development. Consider possible recycling processes for high-cost or potentially hazardous components, to remove another possible impediment to lithium battery use.

\section{Task 3: Identify Cost Reduction Opportunities and Needs}

Estimate battery costs and compare them with USABC cost goals for EV batteries and with PNGV cost goals for HEV batteries. Evaluate opportunities or needs for cost reduction, possibly as the result of R\&D that DOE could support. Areas considered would include materials selection, processing and assembly techniques, and design for recyclability.

\subsection{Report Structure}

Section 2 of this report describes the basic chemistry and physical structure of Li-ion cells and explains how cells are put together into battery packs for vehicles, while Section 3 provides additional detail about the structures within the cell. Section 4 discusses the supply picture and production processes for the materials used within the cells, as well as for the cells themselves. Production costs for the raw materials and the cells are discussed in Section 5. The sensitivity of these costs to various factors is discussed in Section 6, and current and optimistic future battery costs are compared to development goals. Recycling is discussed in Section 7, and Section 8 presents conclusions and discussion of potential future work. 


\section{Section 2 Battery Design}

In this section, we explain the basic chemistry that takes place inside Li-ion battery cells, describe cell construction, and tell how cells are assembled into battery packs for vehicular use. We also indicate for both EV and HEV batteries the quantities of material used per cell and per vehicle and explain the differences between high-energy and high-power cells. Although several manufacturers have pilot-scale facilities for cell production, no automotive cells or battery packs have yet been produced on a commercial scale. Therefore, the designs described here should be considered as exemplary prototypes, from which actual commercial cell designs may differ.

\subsection{Basic Cell Chemistry}

The main feature of Li-ion cells is that current is carried by lithium ions, from the positive electrode (cathode) to the negative electrode (anode) during charging, and from negative to positive during discharging, as shown in Figure 2.1. No lithium metal is present in the cell, thereby alleviating some serious safety concerns. The ions are small and reside within the crystal structure of the electrode materials. The overall cell chemical reactions for cell charging and discharging are shown below, for a typical $\mathrm{LiCoO}_{2}$ cathode and carbon anode:

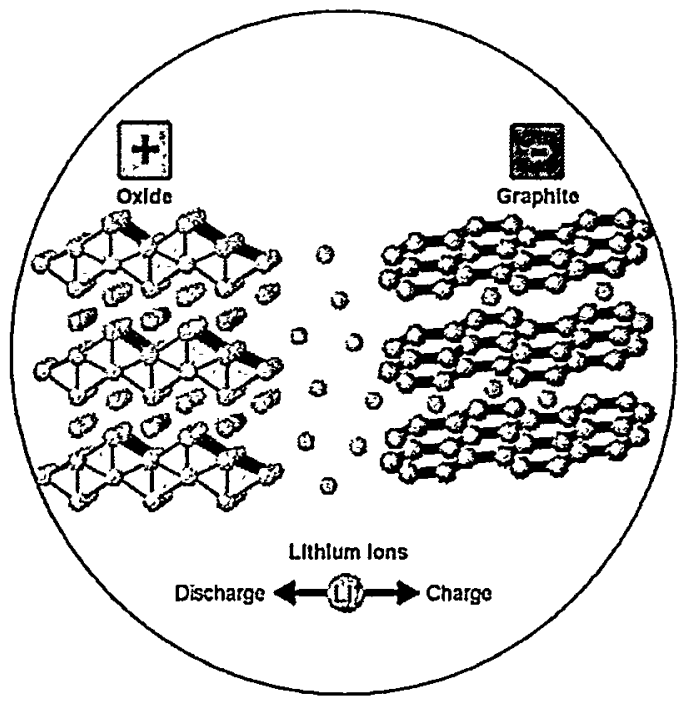

Figure 2.1 Li-lon Cell Operation (Source: Paul Scherrer Institute 2000)

$$
6 \mathrm{C}+\mathrm{LiCoO}_{2} \Rightarrow \mathrm{Li}_{\mathrm{x}} \mathrm{C}_{6}+\mathrm{Li}_{(1-x)} \mathrm{CoO}_{2}
$$

The charge reaction proceeds to the right and the discharge to the left (Kalhammer et al. 1995). As the cell is charged, the lithium ions move to the carbon $(x=1)$ from the cobalt $(x=0)$. In actual practice, not all ions are transported back and forth: $0<\mathrm{x}<1$.

\subsection{Cell Geometry}

The basic cell chemistry and design are the same for all types of Li-ion automotive cells. Figure 2.2 shows a typical cell design. Thin layers of cathode, separator, and anode are rolled up on a central mandrel and inserted into a cylindrical can. The gaps are filled with liquid electrolyte. The basic design remains unchanged on substitution of one electrode material for another, although the layer thicknesses might change. This is the same design used for most small commercial cells, like the $18650,{ }^{1}$ used in such devices as camcorders.

1 The nomenclature refers to the dimensions. The 18650 is $18 \mathrm{~mm}$ in diameter and $65 \mathrm{~mm}$ long. 


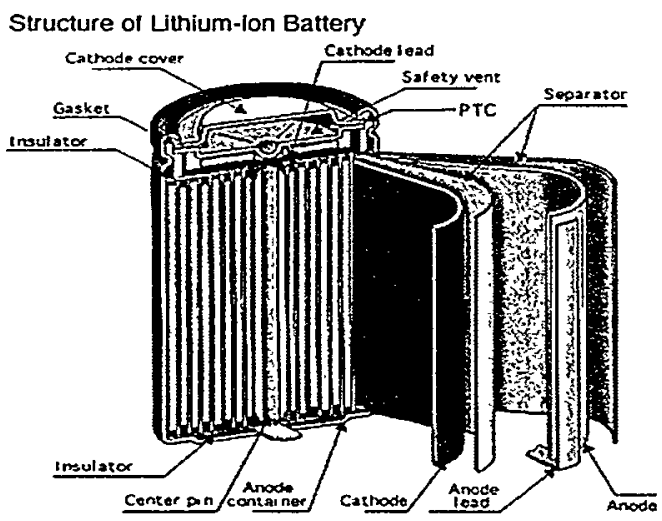

Figure 2.2 Cylindrical Cell Design (Source: Sony 2000)

\subsection{How Cell Types Differ}

Electrical energy requirements for hybridelectric vehicles differ from those for pure electric vehicles, and these requirements affect the cell and battery design. For pure electric vehicles, a large amount of energy must be stored in order to transport the vehicle over an acceptable range. The energy stored in the battery serves the same function as the gasoline in the fuel tank of a conventional vehicle. Typical EV battery packs store on the order of $35 \mathrm{kWh}$, which delivers as much energy to the wheels as about $4 \mathrm{gal}$ of gasoline. It is possible to store as much energy as desired in batteries by simply increasing their number, but this increases the weight to unacceptably high values. Therefore, an important objective in development of batteries for electric vehicles is to maximize energy density, the energy stored per unit volume, or specific energy, the energy stored per unit mass. Li-ion cells can be manufactured with energy densities as high as $175 \mathrm{~W} \cdot \mathrm{h} / \mathrm{L}$ (specific energy, $144 \mathrm{~W} \cdot \mathrm{h} / \mathrm{kg}$ ) today, with a targeted value of $310 \mathrm{~W} \cdot \mathrm{h} / \mathrm{L}$. Lead-acid batteries typically achieve only $73 \mathrm{~W} \cdot \mathrm{h} / \mathrm{L}$ (Oweis et al. 1999).

For power-assist hybrid vehicles, the main source of energy is the liquid fuel; what is needed from the battery is a power boost for rapid acceleration. Therefore, the attribute of the battery to be maximized is specific power or power density. High-power Li-ion cells currently achieve a specific power greater than $1,300 \mathrm{~W} / \mathrm{kg}$ and a power density greater than $2,700 \mathrm{~W} / \mathrm{L}$ (both pulse $50 \%$ depth of discharge, DOD) (Oweis et al. 1999). Cells for dual-mode hybrid vehicles would require a performance level intermediate between those of the high-energy and high-power cells described here.

The main differences between a cell optimized for high energy density, for use in a pure EV, and one optimized for high power, for use in a HEV, are the size of the cell and the relative quantities of the different materials contained in the cell. In this report, we consider the two extremes of design - those for EVs and those for power-assist hybrids, which require much higher power, relative to the available energy (the high-power cell with $1,300-\mathrm{W} / \mathrm{kg}$ specific power has a specific energy of $70 \mathrm{~W} \cdot \mathrm{h} / \mathrm{kg}$, about half that of the high-energy cell). Grid-connected (dual-mode) HEVs require intermediate designs, which we have not examined because of time constraints. We have assumed that costs for these intermediate designs would lie between the two extreme cases.

Both high-energy and high-power cells utilize the same basic spiral-wound design and the same materials. However, some modifications of the designs are required to achieve the desired differences in performance. The high-power cells must be smaller than the high-energy cells in order to dissipate the higher heat load generated. In addition, high-power batteries require less total energy, so battery packs for HEVs can be made smaller and lighter than those for pure EVs. The same current collectors and separators can be used for high-energy and high-power batteries. Control/safety circuits have no significant differences. 
Typical cell dimensions are shown in Table 2.1 for current designs of high-energy and highpower automotive cells. Data on commercial 18650 cells (used in camcorders) are also provided, for comparison.

Table 2.1 Typical Li-Ion Cell Dimensions

\begin{tabular}{|lccrr|}
\hline \multicolumn{1}{|c}{ Item } & SonyHigh-Energy & SAFT High-Energy & High-Power $^{\text {b }}$ & 18650 $^{c}$ \\
\hline & & & & \\
Height (mm) & 410 & 220 & 151 & 65 \\
Diameter (mm) & 67 & 54 & 41 & 18 \\
Mass (g) & 3,300 & 1,070 & 380 & 40 \\
Capacity (A-h) & 100 & 44 & 9 & 1.35 \\
\hline
\end{tabular}

- Oweis (1999).

b Spotnitz (1999a).

c Carcone (1998).

Different designs and capacities are proposed by different manufacturers, and one manufacturer may offer variations. For instance, SAFT's high-power design is available in 6-A.h and 12-A.h sizes, which differ only in capacity and height. In addition, use of smaller cells for vehicles would have both advantages and drawbacks that should be considered. Cell design, then, is by no means finalized. Table 2.2 shows estimated material compositions for typical Li-ion cells.

Table 2.2 Estimated Materials Content of Typical Li-Ion Cells

\begin{tabular}{|c|c|c|c|c|}
\hline \multirow[b]{2}{*}{ Material/Component } & \multicolumn{2}{|c|}{ High-Energy (100-A-h) Cell } & \multicolumn{2}{|c|}{ High-Power (10 A-h ) Cell } \\
\hline & Quantity (g) & $\begin{array}{c}\text { Percent by } \\
\text { Weight }\end{array}$ & Quantity (g) & $\begin{array}{c}\text { Percent by } \\
\text { Weight }\end{array}$ \\
\hline \multicolumn{5}{|l|}{ Negative electrode (dry) } \\
\hline $\begin{array}{l}\text { Anode material (graphite) } \\
\text { Binder (PVDF) }\end{array}$ & $\begin{array}{r}563.6 \\
69.7\end{array}$ & $\begin{array}{r}16.4 \\
2.0\end{array}$ & 14.1 & 4.3 \\
\hline Current collector $(\mathrm{Cu})$ & 151.9 & 4.4 & 41.6 & 12.8 \\
\hline \multicolumn{5}{|l|}{ Cathode (dry) } \\
\hline Active material & $1,408.6$ & 41.0 & 74.4 & 22.9 \\
\hline Carbon & 46.4 & 1.4 & & \\
\hline Binder (polyvinylidene fluoride) & 92.9 & 2.7 & & \\
\hline Current collector (Al) & 63.0 & 1.8 & 19.4 & 6.0 \\
\hline \multicolumn{5}{|l|}{ Rest of Cell } \\
\hline Tabs, end plates, terminal assemblies & 66.2 & 1.9 & 32.2 & 10.2 \\
\hline Core & 0.9 & 0.0 & & \\
\hline Container & 291.0 & 8.5 & 70.1 & 21.6 \\
\hline Electrolyte & 618 & 18.0 & 44.0 & 13.5 \\
\hline Separators & 60.5 & 1.8 & 16.4 & 5.0 \\
\hline Other & & & 12.6 & 3.9 \\
\hline Total & $3,432.7$ & 99.9 & 325 & 100 \\
\hline
\end{tabular}




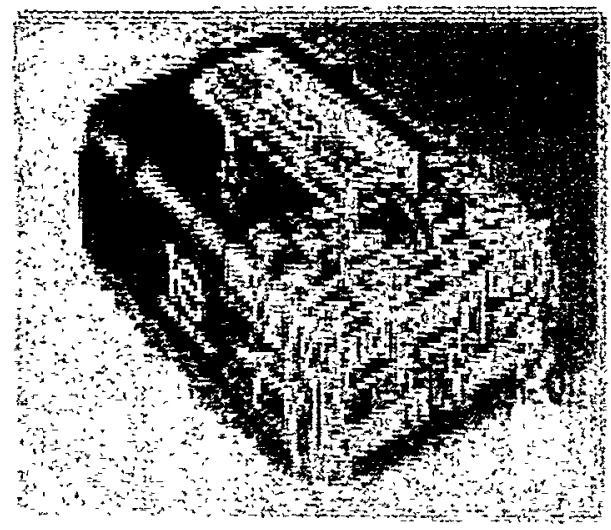

Figure 2.3 Module with Control Circuit (Source: Nissan 1999)

\subsection{From Cells to Modules to Battery Packs}

Numerous designs are possible for assembling cells into a battery pack for an electric or hybrid vehicle. We describe here one representative design for each type. (Actual designs might vary considerably.) A modular design is used in most cases, with a number of cells (between 6 and 12 is typical) packaged together into a unit called a "module." Because Li-ion cells are subject to severe damage on overcharge or overdischarge, control/safety circuitry is included in each module. Figure 2.3 shows the control circuit on top of a module constructed of eight $100-\mathrm{A} \cdot \mathrm{h}$ Sony cells. The modules can then be combined into a battery pack sized to match the requirements of the vehicle. The same modules could be used in a variety of different battery packs.

In the battery pack used in the Nissan Altra, which is the first EV on the road with Li-ion batteries, 12 of the eight-cell modules are assembled into the battery pack for the vehicle (see Figure 2.4 for conceptualization of pack makeup and Figure 2.5 for a photograph of the car). The total mass of the battery pack is $364 \mathrm{~kg}$ (just under $800 \mathrm{lb}$ ), ${ }^{2}$ of which the cells account for $317 \mathrm{~kg}$. The remaining $47 \mathrm{~kg}$ is the circuitry, the module packaging, and the case for the entire battery pack. The approximate size is $100 \mathrm{~cm} \times 200 \mathrm{~cm} \times 18 \mathrm{~cm}$ (40 in $\times 80$ in. $\times 7$ in.); the pack fits under the vehicle's passenger compartment (Roque 1998; Roque and McLaughlin 1999).

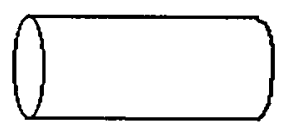

Cell

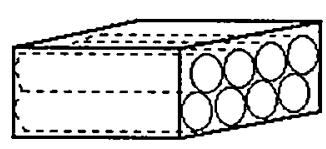

Module

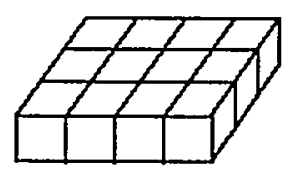

Pack

Figure 2.4 From Cell to Module to Battery Pack

In another EV battery design concept, six 44-A $\mathrm{h}$ SAFT cells would be joined into modules weighing $7.35 \mathrm{~kg}(16 \mathrm{lb}$ ) each. In addition to the mass of the cells, this includes $0.93 \mathrm{~kg}$ for control circuitry and module packaging. The capacity and voltage would depend on how the cells were connected, with the following capacity and voltage pairs possible: $(44 \mathrm{~A} \cdot \mathrm{h}, 21 \mathrm{~V}),(88 \mathrm{~A} \cdot \mathrm{h}, 10.5 \mathrm{~V})$, and (132 A.h, $7 \mathrm{~V}$ ) (Oweis 1999). It would be up to the automobile manufacturer to decide how to package these modules.

One possible design for a high-power battery pack consists of $100 \mathrm{l}$ - $\mathrm{A} \cdot \mathrm{A} \cdot \mathrm{h}$ cells connected in series. SAFT has shown prototypes of two high-power air-cooled modules. These contain either 6or 12-A.h cells. Additional specifications are shown in Table 2.3. For each module, there is

2 Conversion factors: $1 \mathrm{lb}$ (avoirdupois) $\cong 0.454 \mathrm{~kg}$, or $1 \mathrm{~kg} \cong 2.20 \mathrm{lb} ; 1 \mathrm{in} . \cong 2.54 \mathrm{~cm}$, or $1 \mathrm{~cm} \cong 0.394 \mathrm{in}$. 
approximately $1.4 \mathrm{~kg}(3.1 \mathrm{lb})$ of additional material needed for the module case and control circuitry. To meet the PNGV mass and volume goals for power-assist hybrids $(40 \mathrm{~kg}, 32 \mathrm{~L})$, a maximum of six of the $6-\mathrm{A} \cdot \mathrm{h}$ modules or four of the 12-A.h modules could be combined into a battery pack. A photograph of a SAFT $6-A \cdot h$ cell and module is shown in Figure 2.6, and a conceptual battery design using four of the $6-\mathrm{A} \cdot \mathrm{h}$ modules is shown in Figure 2.7. Note that this battery pack is air-cooled; the cooling fan can

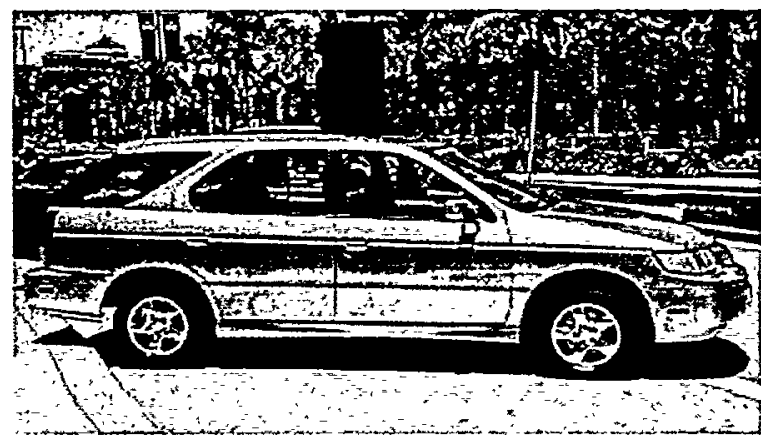

Figure 2.5 Nissan Altra with Li-lon Batteries be seen in the center of the long edge. The pack has a mass of $32 \mathrm{~kg}(70 \mathrm{lb})$, and its dimensions are $71 \mathrm{~cm} \times 30 \mathrm{~cm} \times 15 \mathrm{~cm}$ (28 in. $\times 12$ in. $\times 6$ in.) (volume $=32 \mathrm{~L}$ ).

The new Nissan Tino hybrid, scheduled for road tests in 2000, has two modules under the floor of the passenger compartment, each containing $483.6-\mathrm{A} \cdot \mathrm{h}$ cells. The total mass of the battery pack is $40 \mathrm{~kg}$ (Miyamoto et al. 2000).

Table 2.3 SAFT High-Power Module

\section{Characteristics}

\begin{tabular}{|lll|}
\hline Characteristic & 6-A-h Module & 12-A·h Module \\
\hline Mass, $\mathrm{kg}$ & 6.0 & \\
Volume, $\mathrm{L}$ & 5.2 & 9.5 \\
Dimensions, $\mathrm{mm}$ & $239 \times 153 \times 143$ & 7.7 \\
Energy, $\mathrm{W} \cdot \mathrm{h} / \mathrm{kg}$ & 48 & 61 \\
Peak power, W/kg & 1,125 & 1,150 \\
Peak power, W/L & 1,300 & 1,420 \\
\hline
\end{tabular}

Source: Oweis (1999).

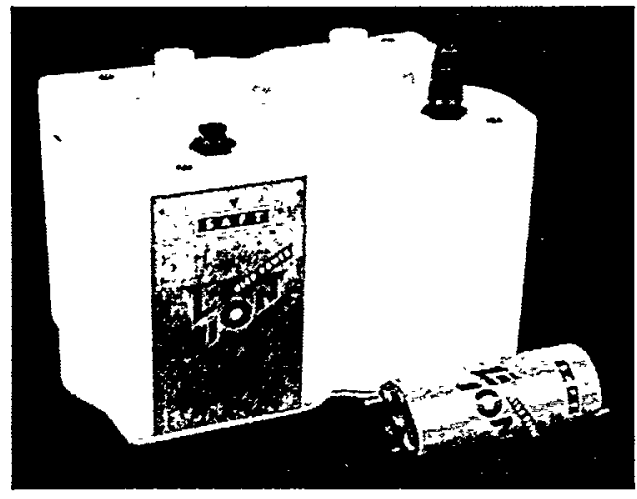

Figure 2.6 SAFT 6-A-h High-Power Cell and Module (Source: Oweis 1999)

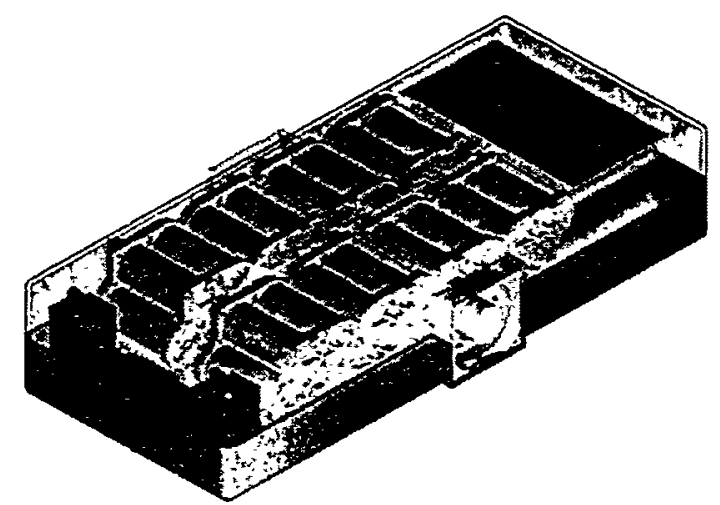

Figure 2.7 SAFT Conceptual Design for High-Power Battery (Source: Oweis 1999) 
$\overline{0}$

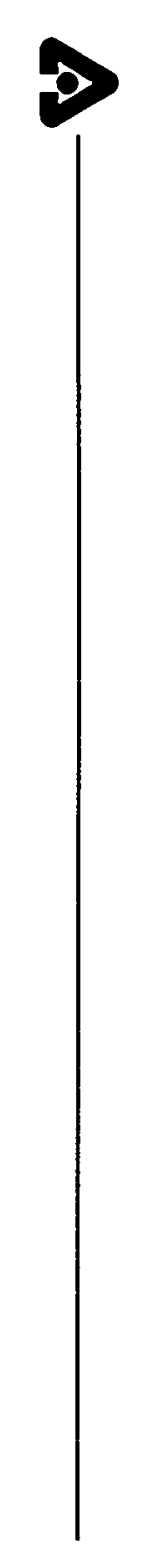




\section{Section 3 \\ Cell Components}

\subsection{Cathodes}

The material used for the cathode (positive electrode) is a metal oxide, in which lithium ions are inserted into the crystal structure, or intercalated. The small, commercial electronics batteries generally use $\mathrm{LiCoO}_{2}$, but cobalt is quite expensive, so there is a considerable incentive for substitution of a cheaper material. Cathode materials based on both nickel and manganese are being developed for vehicle batteries. Sony, which originally used cobalt in its batteries for the Nissan Altra, recently switched to manganese. SAFT and Polystor are developing nickel- or mixed nickel/cobalt-based cathodes, and Varta and Shin-Kobe (Hitachi) are developing cells with manganese-based cathodes. Nickel-based cathodes are feasible now, but manganese-based cathodes are still in the development stage, with a major problem related to the material's solubility in the electrolyte, especially at high temperature.

The lithium cobalt and nickel oxides are layered structures, with lithium and nickel or cobalt occupying alternating layers of octahedral sites in a distorted cubic, close-packed oxygen-ion lattice. The $\mathrm{LiMn}_{2} \mathrm{O}_{4}$ is generally a spinel structure, with the oxygen ions in a face-centered cubic arrangement and the lithium and manganese ions in tetrahedral and octahedral arrays, respectively (Xie et al. 1995). However, Pacific Lithium is now producing a layered aluminum-doped manganite cathode material, developed by the Massachusetts Institute of Technology (MIT), which is expected to have a cost similar to that of the spinel but also to have better performance (Pickering 2000).

Table 3.1 Cathode Material Energy Storage Capacities $(\mathrm{mA} \cdot \mathrm{h} / \mathrm{g})$

\begin{tabular}{|lcc|}
\hline & \multicolumn{2}{c|}{ Capacity } \\
\cline { 2 - 3 } Cathode Material & Practical & Theoretical \\
\hline $\mathrm{LiCoO}_{2}$ & 140 & 275 \\
$\mathrm{LiNiO}_{2}$ (or mixed) & $190-200$ & 274 \\
$\mathrm{LiMn}_{2} \mathrm{O}_{4}$ & 120 & 148 \\
\hline
\end{tabular}

The different electrode materials have different current-carrying capacities, and this affects the storage capacities of the resultant cells. The increase in energy density for nickel, compared to that for cobalt (see Table 3.1), arises because, for cobalt, only $50 \%$ of the lithium ions can be "rocked" (transported back and forth between electrodes). The material becomes less stable as the end-of-charge voltage is increased (maximum voltage is about $4.7 \mathrm{~V}$ ). In contrast, about $70 \%$ of the lithium can be transported at $4.2 \mathrm{~V}$ with nickel-based cathodes (Haskins 1999). The main concern is material stability. Because nickel is inherently less stable than cobalt, researchers are trying to find dopants to make the nickel-based material more stable. Companies often consider the exact percentages of nickel and cobalt used, as well as the dopants used to enhance material stability, to be proprietary.

A typical cathode material under consideration is $\mathrm{LiNi}_{0.8} \mathrm{Co}_{0.2} \mathrm{O}_{2}$. The net impacts of changing the cathode material from $100 \%$ Co to $80 \%-\mathrm{Ni} / 20 \%$-Co are (1) an increase in capacity of $24 \%$ and (2) a reduction in cost (to $20 \%$ ) for $80 \%$ of the material. Nickel and cobalt are so similar in 


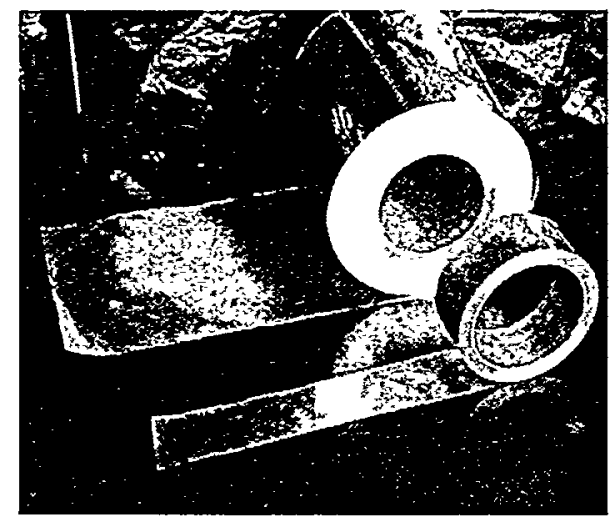

Figure 3.1 Current-Collector Foils (Source: Hohsen Corp. 1998) properties that the dimensions and quantities of material do not really change. However, $24 \%$ fewer cells would be required to achieve the same energy storage in an EV using a nickel-based battery instead of a cobalt-based one. Alternatively, with the same number of cells, the EV would have a larger range. Research is under way to develop novel high-voltage cathode materials. One example is $\mathrm{LiCo}_{y} \mathrm{Ni}_{(1-y)} \mathrm{VO}_{4}$, which is reported to have an inverse-spinel structure (Scrosati 2000).

The electrode materials are spread onto a thin metallic foil substrate, which also serves as the current collector. For the cathode, aluminum foil (about $20 \mu \mathrm{m}$ thick) is used.

\subsection{Anodes}

The anode, or negative electrode, is generally made of graphite, coated on copper foil about $14 \mu \mathrm{m}$ thick, although other forms of carbon can be used. Availability of material for the anodes is not an issue.

In the anodes made by using graphite, a single lithium ion can be intercalated for each hexagon in the graphite's molecular structure, for a nominal composition of $\mathrm{LiC}_{6}$ at full charge. The theoretical capacity of graphite is $372 \mathrm{~mA} \cdot \mathrm{h} / \mathrm{g}$. Development is under way on several other structures that allow intercalation of more than one $\mathrm{Li}$ ion per six carbon atoms. In one type, the graphite planes are disrupted and skewed into a "house-of-cards" structure with an average of two Li ions per six carbons. The distance between planes in graphite is $3.34 \AA$, but it is about $3.8 \AA$ for the less-ordered structure. The best carbons in current research intercalate $2.5 \mathrm{Li}$ ions and achieve capacities as high as $750 \mathrm{~mA} \cdot \mathrm{h} / \mathrm{g}$. This would mean that less anode material could be used to match the capacity of a given cathode. Additional R\&D is being done with metal oxide anode materials (e.g., tin oxide) that offer up to 10 times the capacity of current carbons, but so far these materials are not sufficiently stable (Sandi 1999). Companies involved in R\&D on anode materials include Dupont, 3M, IBM, and FMC. Given the relatively low price of anode materials compared with that of cathode materials, the incentive for research to reduce anode material costs is relatively less compelling.

While maximum porosity of the carbon is sought, minimum effective surface area $\left(<10 \mathrm{~m}^{2} / \mathrm{g}\right)$ is desired at the same time to minimize decomposition by the electrolyte. In some cases, a thin coating of nickel or another metal is deposited on the surface to protect it. Up to $10 \%$ silver has been used in Japan by Hitachi, but this increases the cost considerably. Mixtures of graphite with non-graphitic carbons offer both reduced exfoliation and improved capacity (Sandi 1999). 


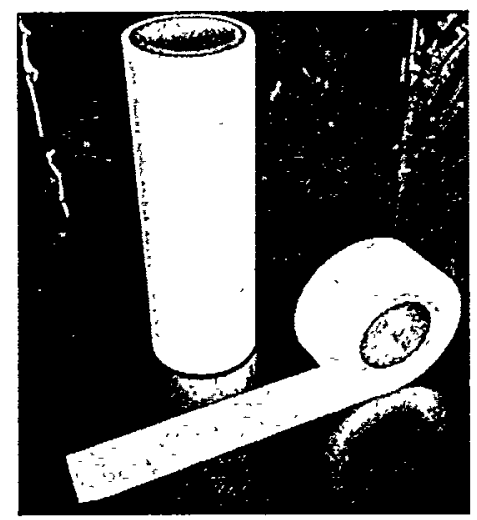

Figure 3.2 Separator Material (Source: Hohsen Corp. 1998)

\subsection{Separators}

Separators for either high-energy or high-power $\mathrm{Li}$-ion batteries are typically made from polyolefins using 3- to $8-\mu \mathrm{m}$ layers (PP/PE/PP or else just $\mathrm{PE})^{3}$ with $50 \%$ porosity.

The separators serve two functions. Not only do they keep the positive and negative electrodes apart, but they serve as a safety device as well. In the event that a cell becomes too hot, the lowmelting polymers melt, closing off the pores through which the ions travel and thereby shutting off the cell current. It is expected that control circuits (see below) will shut the cell down before this happens, since the cell cannot be reused once the shutdown separator melts.

\subsection{Electrolyte}

The electrolyte is usually a 1-molar solution of a lithium salt in an organic solvent. Salts under consideration are listed in Table 3.2, and solvents that could be used in combinations are listed in Table 3.3 (Vimmerstedt et al. 1995). Note that all of the salts are fluorine compounds, which explains both the costs of their production and the potential hazards in the event of fire (HF could be released). Although these salts are very expensive, they are used in relatively dilute solutions in inexpensive solvents. One battery manufacturer uses a mixture of six solvents, increasing the cost but raising the flash point to $60^{\circ} \mathrm{C}$, compared to the typical $5^{\circ} \mathrm{C}$, thereby enhancing the safety of the cells (Ridgway 1999).

There is interest in developing flame-retardant electrolytes. Some work involves using additives to retard flame, rather than replacing the organic solvents. It is unclear whether SRI International's patent (granted in 1998) uses additives or inherently nonflammable solvents (Narang 1998). Ionic liquids, such as 1-ethyl-3-methylimadozolium, are being investigated for use as electrolytes. They are reported to have high ionic conductivity and to be nonflammable, noncorrosive, and formable into gels (Koch 2000).

Table 3.2 Lithium Salts

\begin{tabular}{|lll|}
\hline \multicolumn{1}{|c|}{ Scientific Name } & Formula & Common Name \\
\hline $\begin{array}{lll}\text { (Lithium hexafluoroarsenate } \\
\text { Lithium hexafluorophosphate }\end{array}$ & $\mathrm{LiAsF}_{6}$ & - \\
$\begin{array}{l}\text { Lithium tetrafluoroborate } \\
\text { Lithium (bis)trifluoromethanesulfonimide } \\
\text { Lithium tris(trifluoromethanesulfonyl)methide } \\
\text { Lithium trifluoromethanesulfonate }\end{array}$ & $\mathrm{LiBF}_{6}$ & - \\
& $\left.\mathrm{LiN}_{4} \mathrm{SO}_{2} \mathrm{CF}_{3}\right)_{2}$ & $\overline{\mathrm{Li}}$ TFSI \\
& ${\mathrm{LiC}\left(\mathrm{SO}_{2} \mathrm{CF}_{3}\right)_{3}}_{\mathrm{LiCF}_{3} \mathrm{SO}_{3}}$ & Li Methide \\
& & Li Triflate \\
\hline
\end{tabular}

- Generally no longer under consideration because of its toxicity.

$3 \mathrm{PE}=$ polyethylene, $\mathrm{PP}=$ polypropylene. 
Table 3.3 Organic Solvents

\begin{tabular}{|lc|}
\hline Scientific Name & Abbreviation \\
\hline Propylene carbonate & PC \\
Ethylene carbonate & EC \\
Diethyl carbonate & DEC \\
Dimethyl carbonate & DMC \\
Dimethoxyethane & DME \\
\hline
\end{tabular}

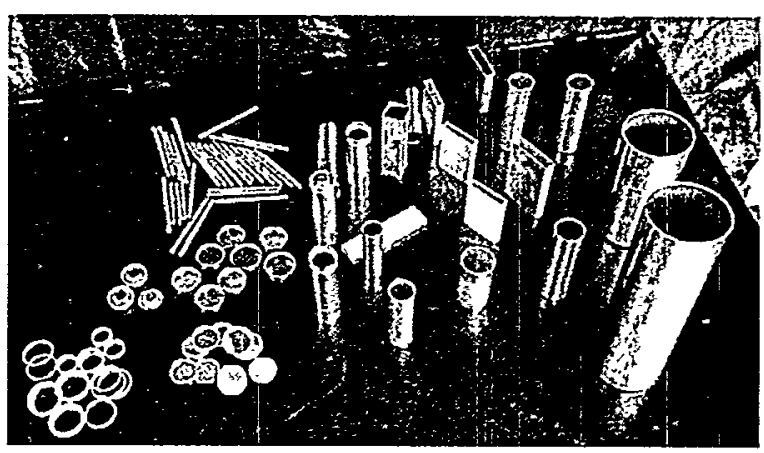

Much research has been directed at the development of gels and solid polymer

Figure 3.3 Cell Cans, Caps, and Mandrels (Source: Hohsen Corp. 1998) electrolytes (SPEs) for Li-ion cells. One developer uses three monomers, a plasticizer, and a lithium salt and polymerizes the mixture in situ. The thickness of the electrolyte for a creditcard-sized prismatic cell, reinforced with synthetic fabric, is 20 to $100 \mu \mathrm{m}$ (Piazza 1998). One plastic often mentioned for use as the polymeric substrate is polyacrylonitrile (PAN). Solid electrolytes would offer several advantages, including enhanced safety (because there is no liquid electrolyte to spill) and lighter weight and design flexibility (because no hard cell can is required). This weight reduction would be most significant for small cells. However, there have been difficulties in achieving the required performance (the electrolyte resistance tends to be too high). Several manufacturers of small consumer cells currently manufacture Li-ion polymer cells. Hydro Quebec and 3M are working on Li-ion polymer batteries for EV applications (Irving 1998).

\subsection{Cell Packaging}

Most automotive cell designs are cylindrical, although some manufacturers do produce prismatic (rectangular) cells. Cases for Li-ion batteries were originally made of stainless steel, but they are now generally aluminum, which is lighter in weight and cheaper. Varta is still using steel, and NEC Moli Energy uses nickel-plated steel for its small consumer cells. The use of plastic is problematic because it could be dissolved by the organic electrolytes.

If solid SPEs were developed, rigid metal cans would not be needed. Aluminum or metallized polymer foils could be used, and cells could be made in a variety of shapes (Hake 1996). The material would need to be sufficiently tough to pass the required abuse tests. Some small cells have been introduced in laminated foil pouches.

\subsection{Safety Circuits}

Li-ion cells require control circuitry to prevent them from overcharging or overdischarging. Essentially the same control circuitry can be used for vehicle cells as for small consumer cells, except that some of the components must be somewhat larger. In addition, automotive battery modules will combine some common components into a single circuit, typically for eight cells (compared with two or four for camcorder packs), so the contribution of electronics to the total cost will be much smaller on a percentage basis. This is particularly important in the case of the highenergy batteries used for pure electric vehicles. Note that cathode material influences the control 
circuit costs; manganese-based cells are self-limiting, and therefore they require only minimal control circuitry (Ridgway 1999).

Li-ion batteries require special protection during charging/discharging and under conditions of abuse. Because Li-ion cells lack an inherent balance-adjusting mechanism, such as the gas recombinative reaction of aqueous electrolyte cells, they need an active external system, especially when many cells are used in series, as in the case of electric vehicles. The basic external control system consists of a bypass circuit controlled by a microchip. When the cell in question reaches a given state of charge (or discharge) in advance of other cells, the bypass circuit is activated, discontinuing the charging (or discharging) process until balance is reached again. The state-ofcharge (SOC) of a Li-ion cell can be detected from its cell voltage, because an excellent correlation exists between SOC and open cell voltage for Li-ion cells. Therefore, the cell controller senses voltage and activates the bypass circuit on and off when the cell reaches near full charge or near discharge. In this way, balance is maintained among all cells, and damage to individual cells by overcharging or overdischarging is avoided. In addition, the protection systems monitor the temperatures of (at least) representative cells and activate cooling systems (e.g., fans) as necessary; protection systems also offer abuse protection from short circuits and other transients.

The protection system is normally implemented by using a controlling microchip (one per battery pack if small, or one per module if many cells are used) and two back-to-back MOSFETs ${ }^{4}$ per cell to close the bypass circuit. Two elements are needed because each MOSFET can block current only in one direction, but the system requires control in both directions during charging and discharging. In a typical EV, the battery pack consists of a number of modules connected in series (or in series and in parallel). Each module may have as many as 12 individual cells. In the Sony implementation, there is one controller and one thermistor per module, but each cell is monitored individually, and there are eight individual solid-state switches (FETs). The module controller actuates the bypass circuits as needed and sends the required information (temperature, voltages, etc.) to the central battery pack controller (a larger microchip), which in turn activates the cooling fans as needed and calculates the overall state-of-charge, potential storage capacity, power level of the battery charger, etc.

In cases of abuse or malfunction, it is possible that $\mathrm{Li}$-ion cells may be exposed to damaging high currents. In such situations, several other safety devices can further protect the cell or limit the damage. Many cells include a current-limiting device, which is placed in series with the electrodes. This polyswitch or PTC (positive temperature coefficient) material consists of a blend of special polymers and conductive components that exist in a crystalline structure with low electrical resistance at room temperature. At high currents, the internal resistance losses increase the temperature of the PTC material, which in turn increases its resistance, thus rapidly controlling the high current. These devices, however, cannot be used on high-power cells. Additional protection to limit damage can be obtained from safety vents that open at a predetermined internal cell pressure to let excess gas escape in a controlled way. Also, the polyethylene layer in the separator film melts when the internal temperature of the cell exceeds a certain limit, thus closing the micropores and preventing ionic exchange, effectively shutting the cell down. Operation of the two last safety

4 FET = field-effect transistor; MOSFET = metal-oxide semiconductor field-effect transistor. 
devices is not reversible, but the damage is limited and further escape of potentially flammable electrolyte is prevented.

\subsection{Module and Battery Pack Materials}

The modules should be packaged in a rigid material so that they keep their shape during installation and vehicle use; this material should not corrode when exposed to the environment. It is also desirable to use inexpensive, lightweight materials. Therefore, battery manufacturers have generally selected plastics for the module housings. Similar considerations apply for the battery pack housing; this material will be selected by the auto manufacturers to fit each model vehicle. For the Nissan Altra, the case for the battery pack is made of recyclable polybutylene terephthalate (PBT) plastic, which is mounted on an aluminum frame (Roque 1998). 


\section{Section 4 Materials and Production Processes}

\subsection{Raw Materials for Cathode Production}

General statistics on production of raw materials to serve as cathode material are shown in Table 4.1 and discussed below. The numbers in the sixth and eighth columns are the numbers of new vehicles that could be powered annually by using the equivalent of current U.S. consumption of these materials. ${ }^{5}$ Of course, many more hybrids could be powered with the same quantity of material. Note that cobalt would be the first material to pose a potential supply constraint, followed by lithium, but there would not be any problems unless EVs achieved significant market penetration (with no additions to material supply).

Table 4.1 Comparative Li-lon Cathode Material Data

\begin{tabular}{|c|c|c|c|c|c|c|c|}
\hline Material & $\begin{array}{c}\text { Import } \\
\text { Sources }^{\circ}\end{array}$ & $\begin{array}{l}1999 \text { World } \\
\text { Mine } \\
\text { Production (T) }\end{array}$ & $\begin{array}{c}1999 \text { U.S. } \\
\text { Consumption } \\
(T)^{\circ}\end{array}$ & $\mathrm{kg} / \mathrm{EV}$ & $\begin{array}{c}\text { U.S. EV/y } \\
\left(10^{3}\right)\end{array}$ & $\mathrm{kg} / \mathrm{HEV}$ & $\begin{array}{c}\text { U.S. HEV/y } \\
\left(10^{3}\right) \\
\end{array}$ \\
\hline $\mathrm{Li}_{2} \mathrm{CO}_{3}$ & $\begin{array}{l}\text { Chile, U.S., } \\
\text { Russia }\end{array}$ & $15,000(\mathrm{Li})^{b}$ & $2,800(\mathrm{Li})$ & $9.6(\mathrm{Li})$ & 292 & $0.46(\mathrm{Li})$ & 6,090 \\
\hline Co & $\begin{array}{l}\text { Nonway, Finland, } \\
\text { Canada }\end{array}$ & 28,300 & 9,200 & 81.4 & 113 & 3.90 & 2,360 \\
\hline $\mathrm{Ni}$ & $\begin{array}{l}\text { Canada, Russia, } \\
\text { Norway }\end{array}$ & $1,140,000$ & $122,000^{c}$ & 81.3 & 1,500 & 3.89 & 31,360 \\
\hline$M n$ & $\begin{array}{l}\text { Gabon, Australia, } \\
\text { Mexico }\end{array}$ & $6,740,000$ & $\sim 220,000^{d}$ & 82.1 & 2,680 & 3.93 & 56,000 \\
\hline
\end{tabular}

- Data from USGS (2000).

- Excluding U.S. production.

c Excluding Ni contained in scrap.

- In ore; excluding ferromanganese.

\subsubsection{Cobalt}

No mining or refining of cobalt took place in the United States in 1999; processors produced cobalt compounds and cobalt metal powder from imported and recycled materials. Much of the world's cobalt is produced as a by-product of copper mining. Because the copper or nickel ores generally contain $10 \%$ or less cobalt compared with their main products, cobalt is inherently in

5 Assuming 96 100-A $h$ cells for EVs and 100 10-A-h cells for HEVs. 
shorter supply, and therefore more expensive, than copper or nickel. Both pyrometallurgical and hydrometallurgical processes are used to recover cobalt from ores (Shedd 1999). The United States imports cobalt from Norway (24\%), Finland (18\%), Canada (14\%), Zambia (13\%), and several other countries (USGS 2000). Imports from Africa have decreased since 1991, in favor of those from Scandinavia and Russia.

Cobalt, considered a strategic metal, has many industrial and military uses; for this reason, the U.S. government established a stockpile. The stockpile is being sold, but about 13,000 T remains. The largest use is in superalloys, used to make jet engine parts; this accounts for $45 \%$ of current U.S. usage. Other major uses include cemented carbides (9\%) and magnetic alloys (8\%). Total reported U.S. consumption in 1999 was $9,200 \mathrm{~T}$, with world mine production at 28,300 T (USGS 2000). One source (Irving 1998) estimated world production of Li-ion batteries at 100 million in 1996, increasing to 700 million by 2001 , which would consume about $4,700 \mathrm{~T}$ of cobalt, or about $17 \%$ of world cobalt production. The total quantity in an EV with a battery pack like the Altra's would be about $81.4 \mathrm{~kg}(179 \mathrm{lb})$, so that all of U.S. cobalt use is the equivalent of about $113,000 \mathrm{EVs}$ per year. This means that U.S. production of a significant number of vehicles that use cobalt-based batteries (tens of thousands annually) could distort the U.S. cobalt market and cause a rise in price. An HEV using $100 \mathrm{10}-\mathrm{A} \cdot \mathrm{h}$ cells would require only $4 \mathrm{~kg}(8.8 \mathrm{lb})$ of cobalt, and so a considerably larger number of HEVs could be produced without causing a major price rise. A similar analysis could be done for world markets, but it is beyond the scope of this study.

\subsubsection{Nickel}

Russia is the world's largest producer of nickel, followed by Canada and Australia. Most nickel is smelted from sulfide ores, but new production in Australia is by hydrometallurgical processes. However, these units are reported to have corrosion problems, which have caused the price of nickel to rise (Kuck 2000). The only U.S. nickel producer, Glenbrook, produced ferronickel (not used in batteries); the company suspended mining in 1996 and idled its smelter two years later because of low nickel prices. Therefore, all primary nickel in the United States is imported, with Canada supplying 38\%, Norway 14\%, Russia 16\%, and Australia 9\% in 1995-1998 (USGS 2000). The bulk of the Norwegian material was recovered from matte imported from Canada and Botswana. The U.S. government no longer stockpiles nickel. All of the material in the National Defense Stockpile was sold between 1993 and 1999 (Kuck 1999).

The apparent U.S. consumption of primary nickel in 1999 was $137,000 \mathrm{~T}$, supplied by imports and recycling of nickel-containing materials, mostly stainless steel scrap. Nickel is used to produce stainless and alloy steel (47\%), to make nonferrous alloys and superalloys (34\%), and for electroplating (13\%) (USGS 2000). The current annual U.S. consumption is equivalent to the amount required for almost 1.5 million EVs with $\mathrm{Ni}$-based batteries, or 31 million HEVs. Annual world mine production is about 1.1 million $\mathrm{T}$, so battery manufacture is unlikely to significantly perturb the nickel market any time soon, if ever. In addition, large reserves are known to exist, and deep-sea nodules offer the possibility of even more supplies to be tapped. 


\subsubsection{Manganese}

Although the United States possesses manganese ore resources, these ores contain less than $35 \% \mathrm{Mn}$, compared to the typical $48-50 \% \mathrm{Mn}$ ore available elsewhere, so it is not economical to use domestic resources. Consequently, the United States imports all of its manganese ore, from Gabon (56\%), Australia (14\%), Mexico (14\%), and Brazil (7\%) (USGS 2000). In addition, a smaller quantity of manganese dioxide is imported from Australia, South Africa, and Ireland. A few U.S. companies produce manganese metal (electrolytically) or $\mathrm{MnO}_{2}$ (chemically or electrolytically). Additional supplies are obtainable from releases of material from the U.S. government stockpile to the market.

Nearly $90 \%$ of U.S. manganese is used in the iron and steel industry, for sulfur fixing, deoxidizing, and alloying. U.S. consumption decreased in the 1980 s in response to somewhat reduced steel production levels and because technological change reduced the rate of consumption per ton of steel. Apparent U.S. consumption in 1999 was estimated as $745,000 \mathrm{~T}$, or about $11 \%$ of world mine production (USGS 2000). The world reserve base is sufficient for 675 years' production at current rates, without deep-sea nodules, so supply is not an issue. The annual U.S. consumption is equivalent to the material needed for over 2.7 million $\mathrm{EVs}$ with manganese-based $\mathrm{Li}$-ion batteries, or about 56 million HEVs. Therefore, vehicle batteries are very unlikely to make even a ripple in the U.S. manganese market.

\subsubsection{Lithium}

Lithium need not be produced in metallic form for use in $\mathrm{Li}$-on batteries. In fact, very little metallic lithium is used, and because that small amount is used where it is produced, it is not a market commodity. The required raw material for these batteries is lithium carbonate. Until recently, the United States was the world's largest producer, providing almost $80 \%$ of the world's supply in 1976, from mines in North Carolina, California, and South Dakota and from brines in Nevada, but only the Nevada operation is still open. Production from brines in South America began in the mid1980s, and Chile is now the world's largest supplier, followed by China, Russia, and the United States. Almost all lithium carbonate imports to the United States come from Chile, but data on our current degree of import reliance are not available.

The large new operations, especially in South America, recover lithium carbonate through the concentration of mineral-rich brines more economically and with less energy use than production from ore. In one operation, brines averaging $300 \mathrm{ppm}$ lithium chloride are evaporated in ponds for a year or more until the concentration rises to $6,000 \mathrm{ppm}$. The concentrate is treated with soda ash to precipitate lithium carbonate, which is filtered out and dried for shipment.

The United States is still the world's largest lithium consumer, as well as the leading producer of value-added lithium chemicals. Major uses are in the production of ceramics, glass, primary aluminum, and lubricants and greases. None of these uses is considered strategic, and the U.S. government does not stockpile lithium, although the U.S. Department of Energy did have a stock of lithium hydroxide monohydrate. U.S. consumption in 1999 was estimated to be about $2,800 \mathrm{~T}$ of contained lithium (USGS 2000). This quantity is equivalent to that required for about 290,000 EVs with Li-ion batteries annually, or about 6 million HEVs. Therefore, significant market 
penetration by EVs with Li-ion batteries would perturb the market and require expansion of imports or U.S. production. Total world production in 1999 was about 15,000 T of contained lithium (63\% in carbonates), and world reserves exceed 12 million T (USGS 2000). Therefore, long-term supply should not be a major concern.

\subsection{Cathode Active Material Production}

The lithium metal oxide cathode compounds are made from lithium carbonate and a salt of the chosen metal by means of a series of chemical replacement reactions performed in solution. The desired product is precipitated and spray-dried. Special care is required in process design and operation in order to achieve the appropriate crystalline and/or particle geometry (spherical for the cobalt-based or nickel-based cathodes). The processes are not particularly capital-or labor-intensive, although special care is required to handle the powders, especially the nickel oxides, because some nickel salts and oxides may be toxic and/or carcinogenic.

\subsection{Anode Production}

The important factor in the purity of the anode material is the need to eliminate any oxygencontaining species on the surface because these would react with the electrolyte. To prevent this reaction, manufacturers bake the graphite at $2,000^{\circ} \mathrm{F}\left(1,100^{\circ} \mathrm{C}\right)$ in reducing or inert atmospheres. This increases the cost for other uses, compared to graphite.

Carbon (90\%) is mixed with several other ingredients to make the anode paste or slurry. As with the cathode, polyvinylidene fluoride (PVDF) is used as a binder $(\sim 5 \%)$, and a small amount of carbon black is added to ensure conductivity. In addition, n-methyl pyrrolodinone (NMP) is used to solubilize the materials to form a uniform mixture. Pressure assures uniform grain size (Sandi1999).

\subsection{Separator Production}

Two types of process are available: wet and dry. The Japanese manufacturers use a wet process in which the polymer is dissolved in oil. The oil is then evaporated to leave a porous film. They use polymers of ultrahigh molecular weight, which are stronger than shorter-chain compounds.

In the dry process, used in the United States by Celanese to produce Celgard ${ }^{\mathrm{TM}}$, three layers of blown polymer film are laminated, drawn down, and annealed below the melting point to control the polymer structure. The sheet is then rapidly stretched to obtain porosity (Pekala et al. 2000). This process is very sensitive to operating conditions and even varies with material batches, so careful control is necessary (Hoffman 1999; Spotnitz 1999b). This process is limited in the molecular weights of the polymers it can use, so the product is not quite as strong as that from the wet process (Spotnitz 1999b). However, the additional thickness required in separators for EV/HEV cells compensates for the reduced strength. 


\subsection{Battery Production Process}

The processes used for production of small, commercial Li-ion cells (size 18650) are described here. Essentially the same processes could be used for production of larger cells for electric or hybrid vehicles.

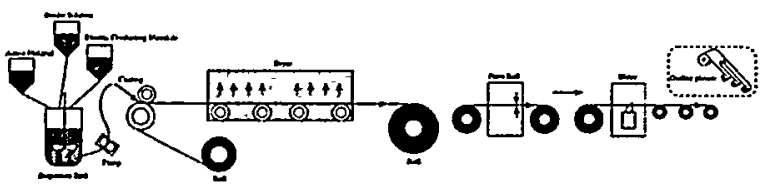

Figure 4.1 Winding Production (Source: Hohsen Corp. 1998)

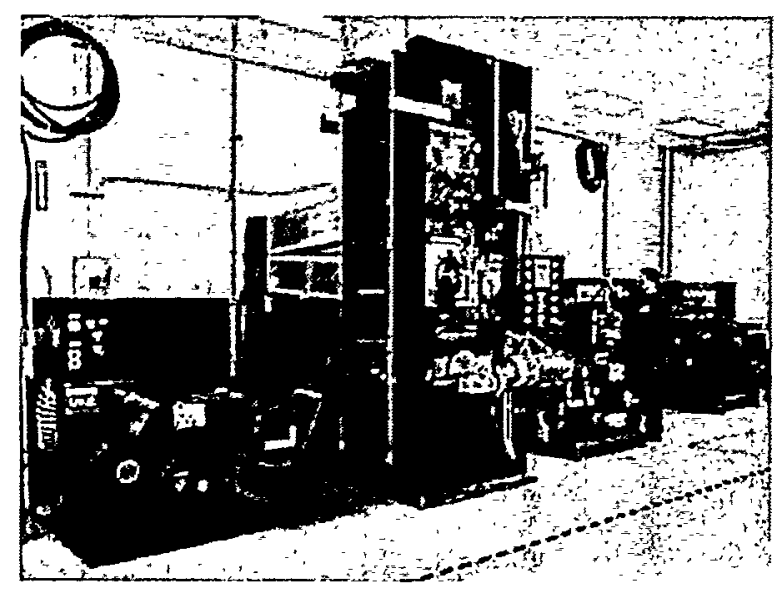

Figure 4.2 Calendering Machine (Source: Polystor Corp., Inc., 2000)

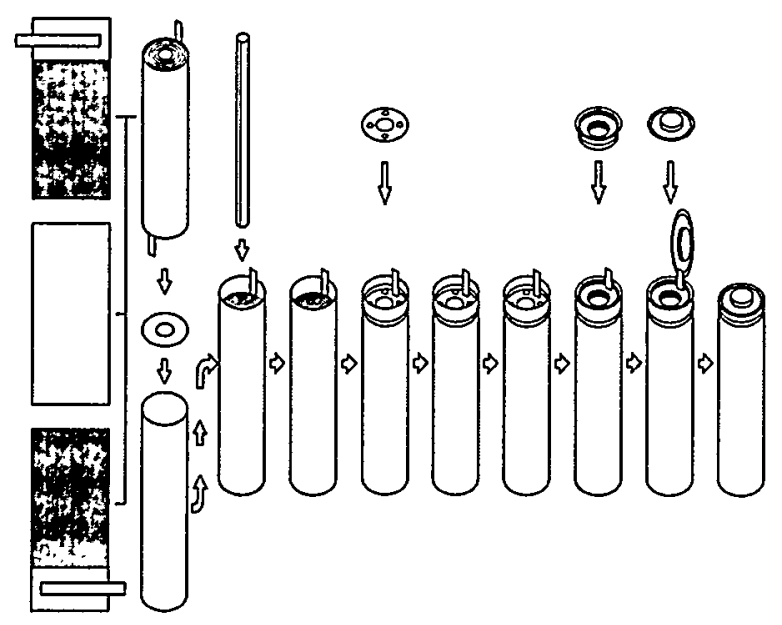

Figure 4.3 Cell Assembly Process (Source: Hohsen Corp. 1998)
1. A cathode paste is made from purchased $\mathrm{LiCoO}_{2}$ powder (80-85\%), binder powder (10\% PVDF), solvent, and additives $(\sim 5 \%$ acetylene black $[\mathrm{AB}]$, with some NMP) in a chemical vessel and pumped to the coating machine.

2. Coating machines spread the paste to a thickness of about 200 to $250 \mu \mathrm{m}$ (for high-energy cells) on both sides of the $\mathrm{Al}$ foil (about $20 \mu \mathrm{m}$ thick, purchased in rolls). Drying reduces the thickness by 25 to $40 \%$. The coated foil is calendered to make the thickness more uniform and then slit to the correct width. (Figure 4.1 shows winding production, with coating machine at left and calendering at right. Figure 4.2 shows an actual calendering machine.)

3. Graphite paste is produced in a process similar to that used for the cathode paste. The graphite paste is then spread on $\mathrm{Cu}$ foil to produce the anodes. The same machines used for the cathodes can be used. A small amount of material is trimmed off the edges of the foils. There is also a small amount of material lost when a new roll of foil is spliced in, because the taped area must be cut out.

4. The anode, (purchased) separator, and cathode layers are wound up and inserted into (purchased) cylindrical cases. (Figure 4.3 is a schematic of the cell assembly process, and Figure 4.4 shows a modern, automated assembly line.) In the process, the electrodes each get a foil 


\section{$\triangle$}

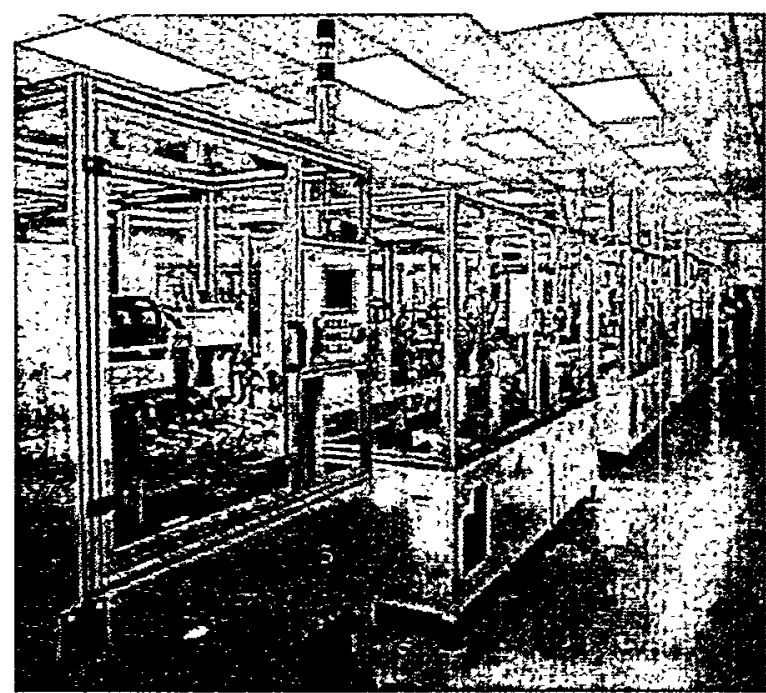

Figure 4.4 Automated Cell Assembly Line (Source: Polystor Corp., Inc., 2000) conducting tab welded on, which will be welded to the appropriate electrical connections (the anode is welded to the can and the cathode to the can top during assembly [step 6]).

5. Cells are filled with electrolyte, purchased premixed from a chemical house.

6. Insulators, seals, valves, safety devices, etc. are attached, and the cells are crimped closed (or welded).

7. Cells, fabricated in a fully discharged condition, are charged by using a "cycler." These cyclers will have to provide high current for EV batteries. Cells are conditioned and tested (times up to about three weeks have been reported); they are charged, left on the test stand for several days, and then discharged; this cycle is repeated four times to verify product quality. The amount of energy used for this is not significant, but a fire hazard could exist because of the large inventory of batteries being tested.

8. Cells are filled with electronic circuit boards to control charging/discharging and packed into cases. For large automotive cells, bypassing may be more difficult.

9. Defective cells (about $1 \%$ ), nonhomogeneous electrode materials, and leftover separator go to scrap. The total amount of scrap has been (or, it is hoped, could be) reduced to an insignificant cost factor. However, scrap rates may be higher, with one material supplier reporting that as little as $40 \%$ of the input materials in some operations winds up in final products (Pickering 2000). This question calls for additional investigation; no commercial operation rejecting that much expensive material could remain competitive. 


\section{Section 5 Material and Production Costs}

\subsection{Material Costs}

In general, costs of material production are high for new products for two reasons. First, where the process is new, even if it is modeled on a similar one, experience is needed to optimize it. Each additional new plant incorporates minor improvements on the process "learning curve." New technologies can bring larger improvements. Second, a new product is generally produced in small quantities. A special set-up is required; existing equipment may have to be modified to be suitable. Small quantities are generally produced in batches, but as the scale increases, continuous processes that utilize specially designed equipment are introduced. Eventually, as product demand increases, the maximum practical equipment size is reached (the limit of the economies of scale), and additional demand must be satisfied by means of duplicate production lines. In the following sections, where current and projected material prices are discussed, we attempt to separate the two effects whenever possible. However, they are not entirely independent; in many cases, a new technology is developed that is only practical at large scales; therefore, reductions in cost as production volume increases cannot always be attributed to either improved technology or economies of scale alone.

\subsubsection{Cathode Active Materials}

The main source of data on minerals is a series of reports on mineral commodities, currently published by the U.S. Geological Survey (USGS), and previously by the U.S. Bureau of Mines. The reports represent by far the most complete and up-to-date information available on these materials, and they are all available on the World Wide Web. Statistics are reported in the Mineral Industry Surveys (monthly) and Mineral Commodity Summaries (annual). A detailed discussion of the historical variations in the prices of these minerals is provided in Metal Prices in the United States through 1998 (USGS 1998). The USGS commodity specialists ${ }^{6}$ also graciously provided additional insights.

All of the mineral raw materials are already established commodities, with well-developed production processes and infrastructure. Process improvements could reduce production costs somewhat, but production already takes advantage of any scale economies. The major source of price variations for these materials is, and will remain, potentially significant market fluctuations associated with supply and demand.

6 The specialists for the relevant materials are Kim Shedd (cobalt), Peter Kuck (nickel), Thomas Jones (manganese), and Joyce Ober (lithium). 


\subsubsection{Minerals}

Cobalt. The historical average annual price of cobalt, from 1959 to 1998 , is plotted in Figure 5.1. The price was low (less than $\$ 11 / \mathrm{kg}$, or $\$ 5 / \mathrm{lb}$ ) and flat until the late 1970 s, when the African copper/cobalt-producing region was invaded and the price spiked sharply, to over $\$ 70 / \mathrm{kg}$ $(\$ 32 / \mathrm{lb}){ }^{7}$ Since that event, the price has never quite recovered its very low level or its stability. Weekly spot prices vary even more sharply than do the annual averages, which themselves have varied by as much as $\$ 10 / \mathrm{lb}$ from year to year, with the maximum at about $\$ 29 / \mathrm{lb}$ in 1995 (USGS 1997).

The price of the $99.8 \%$ pure cobalt required for batteries is about $\$ 2 / \mathrm{lb}$ higher than the price of the $99.3 \%$ purity material in the historical graph. The price of the purer material peaked at $\$ 23 / 1 \mathrm{~b}$ in June 1999, then fluctuated within about $\$ 2$ of $\$ 19 / 1 b$ during the rest of 1999 and early 2000 , as shown in Figure 5.2. The per-pound price fluctuated between $\$ 16.00$ and $\$ 17.25$ during the week ending April 14, 2000 (MetalPrices LLC 2000a). The potential exists for further price decreases as the U.S. government sells off its National Defense Stockpile and new supplies are developed. Three new nickel projects began production of by-product cobalt in Australia in 1999 (but have experienced corrosion problems since startup [Kuck 2000]), and several other projects in other parts of the world are under consideration, including some that would recover cobalt from stockpiled tailings, slags, and concentrates. Since many of these projects are in stable areas of the world, the potential for major price disruptions in the future is expected to be small. An optimistic projection (for batteries) would put the future price of cobalt at about $\$ 10 / \mathrm{lb}$. Although the supply additions are expected to be greater than the increase in demand associated with superalloys and batteries, rapid growth in use for EV batteries could eventually strain supplies, driving the price back up. At $\$ 10 / \mathrm{lb}$, the cobalt required for a battery pack like that in the Altra would cost over $\$ 800$, and that in an HEV would cost about $\$ 40$; at a price of $\$ 18 / \mathrm{lb}$, the cobalt would cost almost $\$ 1,500$ for an EV and $\$ 70$ for an HEV.

Nickel. The average annual price of nickel has been rising slowly but steadily for the past 40 years, from less than $\$ 1 / \mathrm{lb}$ to about $\$ 2 / \mathrm{lb}$ in 1998 , as can be seen in Figure 5.3; recent fluctuations have been on the order of $\$ 1 / \mathrm{lb}$. (Note that in constant dollars, the price has actually gone down.) An exception occurred in the late 1980 s, when a price spike to over $\$ 6 / 1 \mathrm{~b}$ was caused by a supply shortage. Historically, the price has risen during wartime because of strategic demands. The price rose during 1999 to over $\$ 3.20 / \mathrm{lb}$. At this price, the material in a nickel-based EV battery would cost about $\$ 260$, and that in an HEV would cost $\$ 12$. The price of nickel in early 2000 was over $\$ 4 / 1 b$, because of strong demand for stainless steel and because of corrosion problems at new facilities in Australia (Kuck 2000). (The high, in March 2000, was about \$4.70/lb [MetalPrices LLC 2000b].) There are also short-term fluctuations, as can be seen in Figure 5.4, which shows London Metal Exchange (LME) prices for the past year. Although limited quantities of metal are actually traded on the LME, the exchange serves to set a reference price used by the producers. Several new projects in various parts of the world should supply enough nickel to keep prices down in the future.

Development of the huge Voisey Bay deposits by Inco would further increase the Canadian supply. An environmental panel overseeing the project recommended in March 1999 that it proceed,

7 Conversion factors: $1 \mathrm{lb}$ (avoirdupois) $\cong 0.454 \mathrm{~kg}$, or $1 \mathrm{~kg} \cong 2.20 \mathrm{lb}$. Units listed first are those originally cited. 


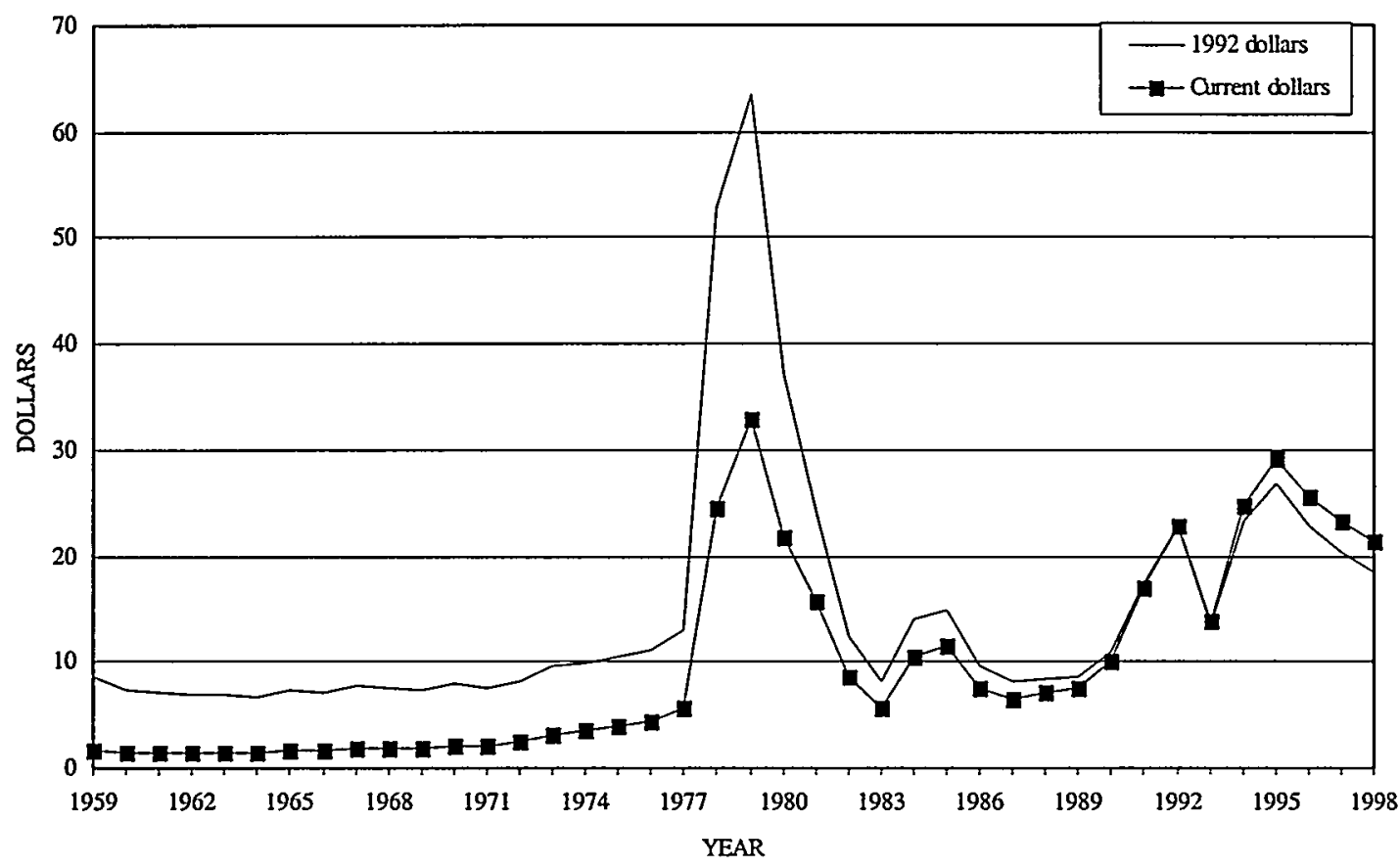

Figure 5.1 Historical Price of Cobalt (Source: USGS 1998)

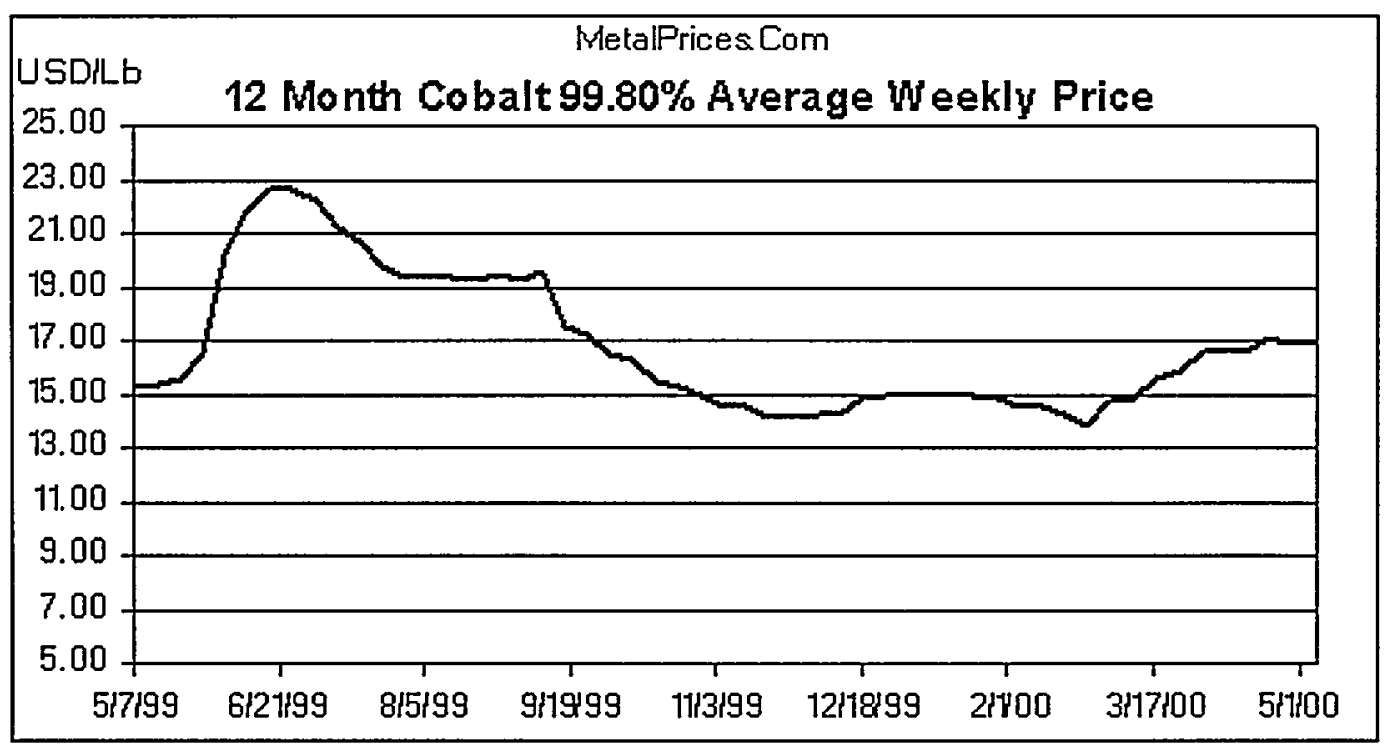

Figure 5.2 Average Weekly Cobalt Price (Source: MetalPrices LLC 2000a) 
ANUAL AVBAAGENOKE PRCE

(Dollars per pound)

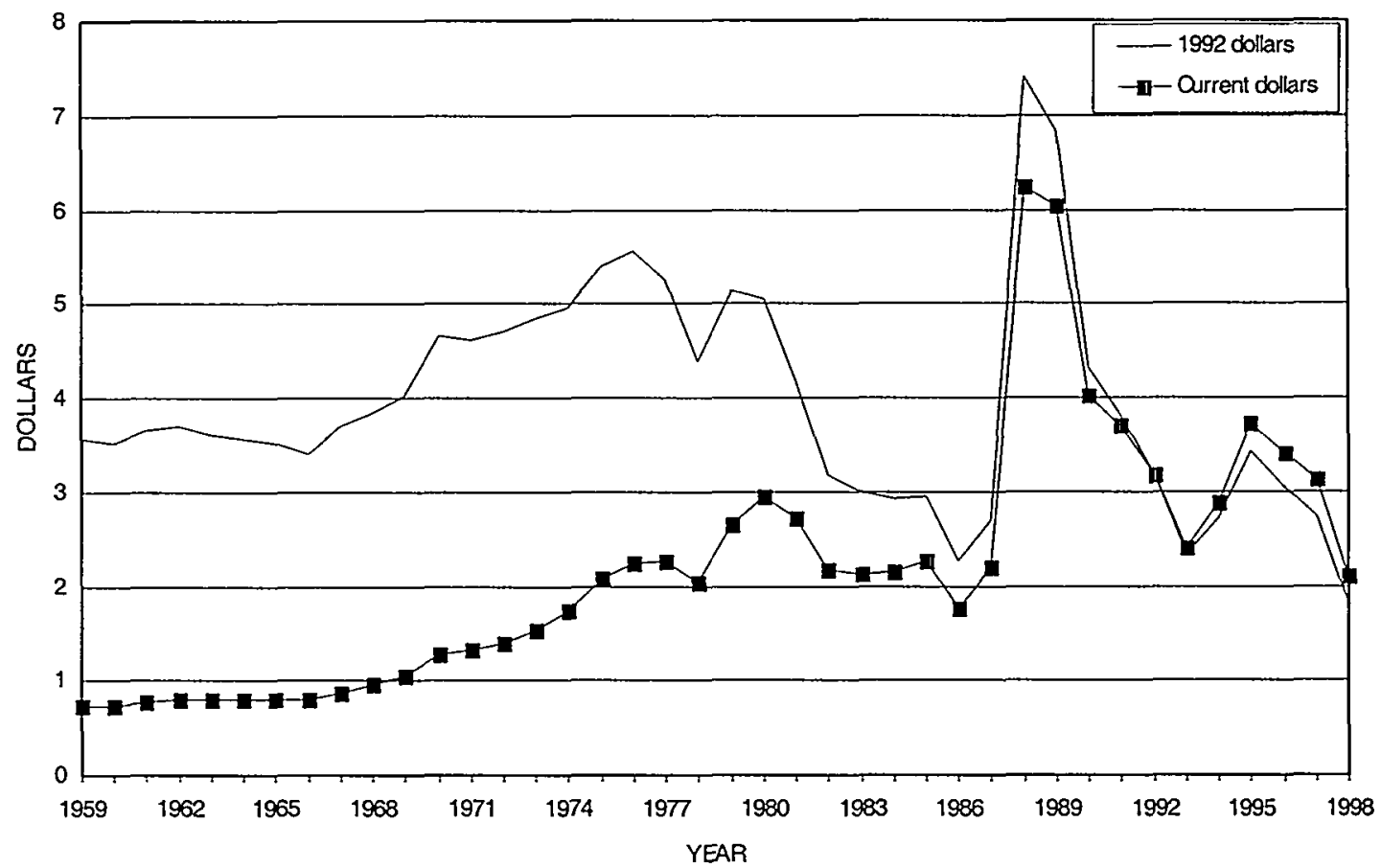

Figure 5.3 Historical Price of Nickel (Source: USGS 1998)

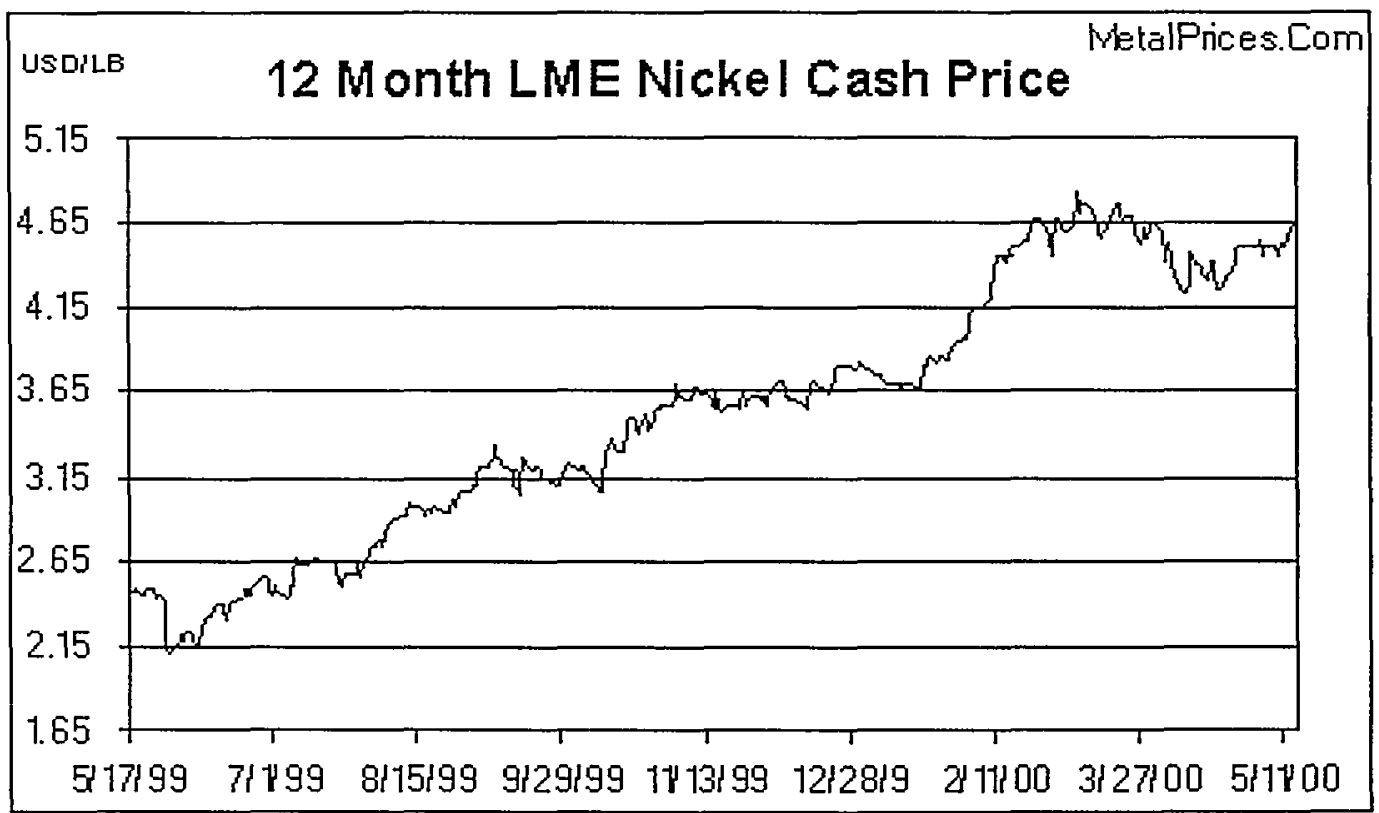

Figure 5.4 Nickel Cash Price Variations (Source: MetalPrices LLC 2000b) 
and production could begin in 2002. Russian production (which entered the western market when the Soviet Union collapsed and domestic demand plummeted) by Norilsk is growing, which has driven prices down somewhat. However, Norilsk is hindered by difficulties in financing the costly systems required to capture the sulfur dioxide emissions from nickel smelting (Kuck 1996). Russian nickel (and also stainless scrap) is expected to be largely exported until at least 2025. Norilsk Nickel recently launched a program to modernize and expand its operations on the Taimyr peninsula in north-central Siberia. In addition to the large and growing supplies from Canada and Russia, three new projects in Western Australia, commissioned in 1999, have begun producing limited amounts of nickel (Kuck 2000). These new projects are all based on high-pressure leaching of nickel (and cobalt) from laterite ores, a process that is expected to have lower operational costs than smelting. This new supply at reduced cost is expected to exert further downward pressure on nickel prices. The increased number of sources could also help to prevent large fluctuations in price.

According to Kuck (1999), the price of nickel "is driven by world supply and demand, irrespective of production costs" (although producers are likely to drop out if prices go below their costs). Although supply is expected to continue to grow, demand for use in stainless steel production, which has a strong influence on nickel prices, is also expected to continue to grow at its historical rate of $4.5 \%$ annually for the next 20 years. Unforeseen demands, such as a shift to stainless steel space frames for automobiles (considered by the PNGV), could raise the growth rate. Thus, in spite of increasing supply, no large drop in the price of nickel is anticipated.

Manganese. Very little manganese metal is traded or used, so the basis for quoting prices is that for ore, expressed in terms of the "metric ton unit" (mtu): $1 \mathrm{mtu}$ is equal to $10 \mathrm{~kg}$ of contained manganese. Thus, if the price is $\$ 2 / \mathrm{mtu}$, this is equivalent to $\$ 0.20 / \mathrm{kg}$ of manganese. However, if the ore grade is $50 \%$, then this is equivalent to $\$ 0.10 / \mathrm{kg}$ or $\$ 100 / \mathrm{T}$ for the ore. The price of manganese is relatively stable, with no obvious factors on the horizon to change it. Unlike cobalt or nickel, manganese is not traded on the LME, and most purchasers have annual contracts. As shown in Figure 5.5, there was one notable disruption in the late 1980s, when the Soviet Union and China

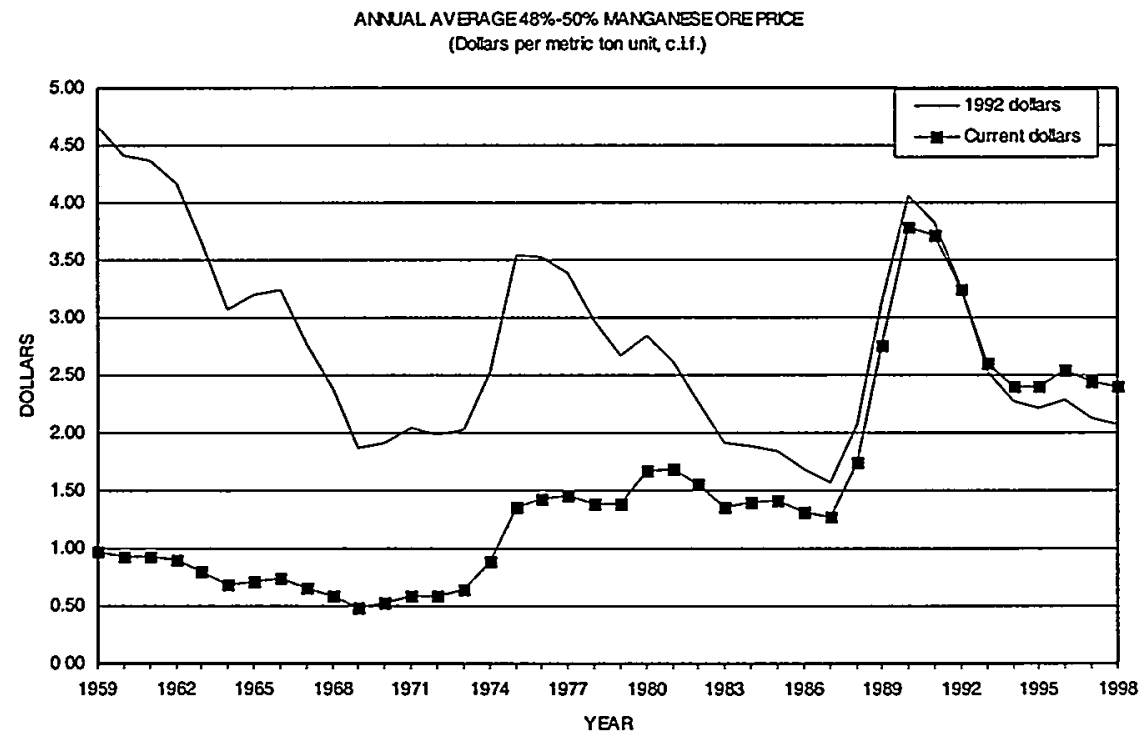

Figure 5.5 Historical Price of Manganese (Source: USGS 1998) 
started purchasing large quantities of manganese ore and the price rose to almost $\$ 4 / \mathrm{mtu}$. The average 1999 price was about $\$ 2.30 / \mathrm{mtu}$ (USGS 2000).

The price of manganese is highly dependent upon steel production. Battery usage would be insufficient to affect manganese prices. Manganese ore is so cheap that the quantity contained in an EV would cost less than $\$ 20$ at current prices; it is the cost associated with production of the cathode material from it that will dominate the cathode cost for manganese-based batteries. Manganese contained in pure compounds is somewhat more expensive. The manganese in electrolytic manganese dioxide (the appropriate precursor for cathode active material), which itself costs about $\$ 1,600 / \mathrm{T}$, costs about $\$ 2.67 / \mathrm{kg}(\$ 1.21 / \mathrm{lb}$ ) (Jones 1999). At that price, the manganese in an EV would cost $\$ 219$, and that in an HEV would cost $\$ 10.50$.

Lithium. Lithium metal is costly (about $\$ 50 / \mathrm{lb}$ ), but the pure metallic form is not required for Li-ion cells. The actual lithium compound used to make cathode materials, lithium carbonate $\left(\mathrm{Li}_{2} \mathrm{CO}_{3}\right)$, is considerably less expensive. The price history of lithium carbonate is shown in Figure 5.6. The average price reported for lithium carbonate in the United States at the end of 1999 was $\$ 4.47 / \mathrm{kg}(\$ 2.03 / \mathrm{lb})$. However, increased production in Chile and Argentina has led to a recent oversupply, and actual prices paid have been as much as $50 \%$ below the list, matching the price of only $\$ 0.90 / \mathrm{lb}$ from Chile and Argentina. A shutdown of the Argentine production due to process problems caused the price to rise again, but the price was still below list in early 2000 (Ober 2000). Recycled materials and sales from DOE stock put further downward pressure on prices. Large demand for batteries could eventually drive the price up. At the current list price, the lithium carbonate for the batteries in an EV like the Altra would cost about $\$ 100$, and the material for an HEV battery would cost about $\$ 5$.

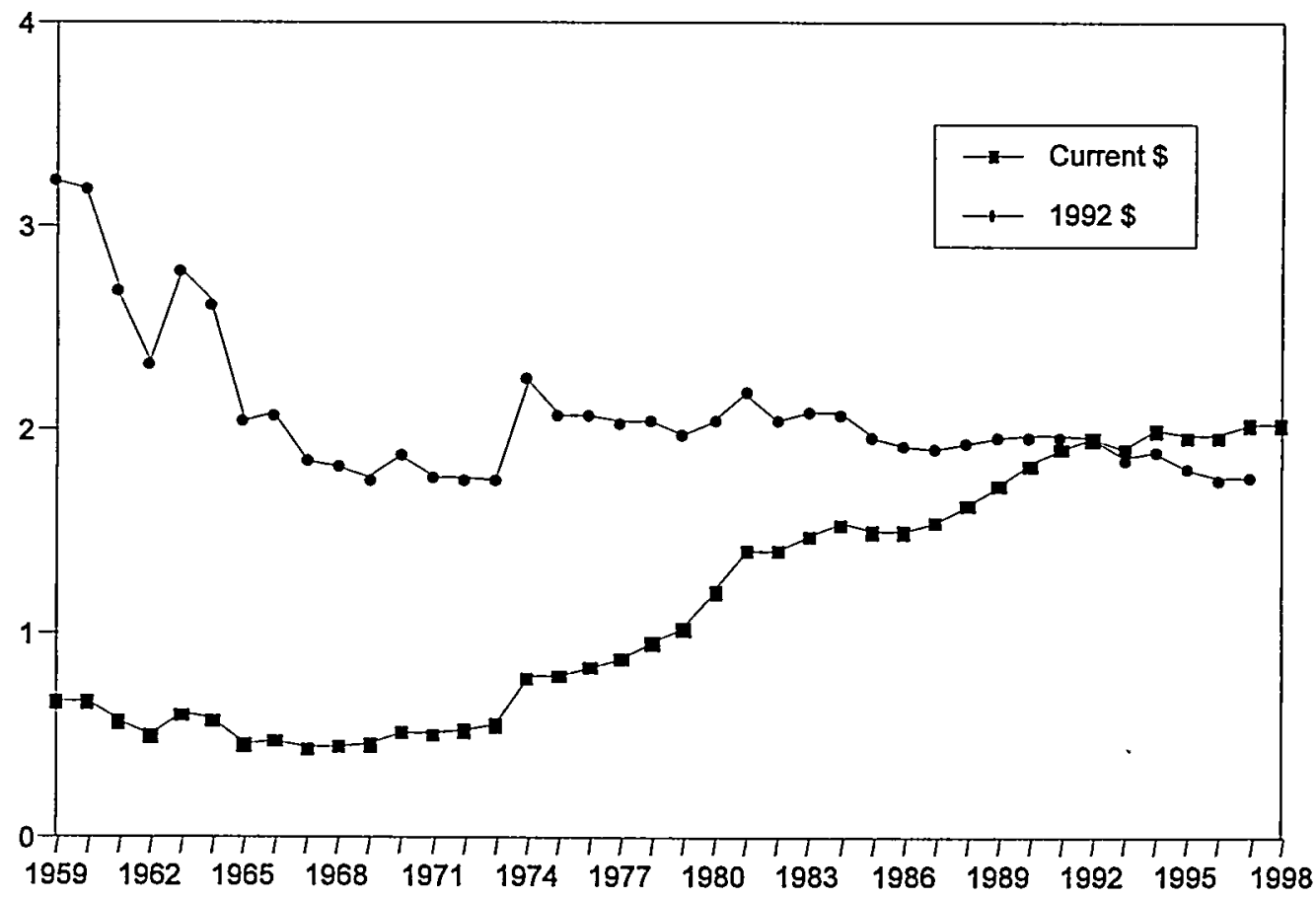

Figure 5.6 Historical Price of Lithium Carbonate (Source: Ober 1999) 


\subsubsection{Lithium Metal Oxides}

The total quantity of $\mathrm{LiCoO}_{2}$ produced worldwide in 2000 will only be on the order of $6,000 \mathrm{~T}$, which is a relatively small quantity compared to other industrial chemicals (e.g., $\mathrm{TiO}_{2}$ at about 1.3 million $\mathrm{T}$ annually) (American Chemical Society 1996). Therefore, the potential exists for some cost reduction by production on a larger scale, but it is unlikely that sufficient quantities will ever be produced to realize full economies of scale. The extremely tight specifications on cathode materials greatly increase production costs. The main determinant of price will remain the cobalt price. Cobalt, even at $\$ 18 / \mathrm{lb}$, makes current $\mathrm{LiCoO}_{2}$ cathodes especially expensive, representing $60 \%$ or more of the late 1999 high-volume cathode material price of about $\$ 25 / \mathrm{lb}(\$ 55 / \mathrm{kg}$ ) (Chappell 1999). The price is highly dependent on the quantity purchased, as can be seen for cobalt-based cathode material in Figure 5.7. Manufacturers consider high volume to be tens of tons per month.

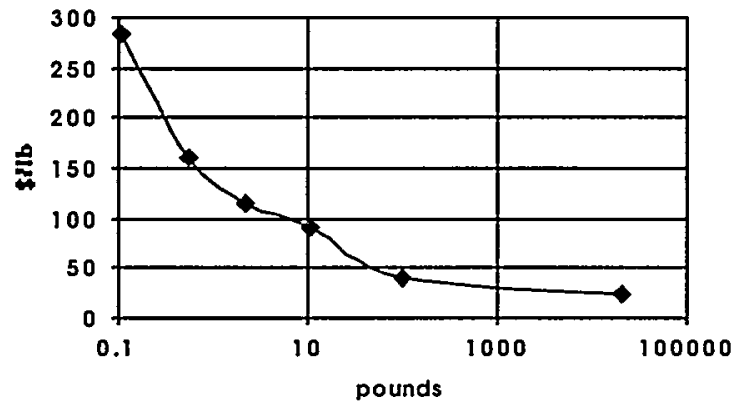

Figure 5.7 Cathode Active Material Price vs. Quantity

The $\$ 25 / \mathrm{lb}$ price is a reduction of about $40 \%$ from the price a few years ago. If the price of cobalt metal were to drop to $\$ 10 / \mathrm{lb}$ $(\$ 22 / \mathrm{kg})$, the price of cobalt-based cathode material could come down to about $\$ 14 / \mathrm{lb}$ $(\$ 31 / \mathrm{kg})$, below the $\$ 16-\$ 20 / \mathrm{b}(\$ 35-\$ 40 / \mathrm{kg})$ drop considered likely by expert opinion in the industry. There is an economic incentive, then, to switch to nickel, even at $\$ 4 / \mathrm{lb}$, and especially to manganese. However, production of $\mathrm{LiMn}_{2} \mathrm{O}_{4}$ is reported to be more difficult than production of $\mathrm{LiNiO}_{2}$, because higher temperatures and pressures are required for the former, and because several crystal structures are possible, only one of which has the desired properties. Thus, it is unclear what the cost of a viable manganite electrode would be, if developed. The manganite cathode material has significant potential for cost reduction by development of more specific processes, or those based on a different crystal structure (e.g., the linear structure developed by MIT and being pursued for production by Pacific Lithium). Although nickel and manganese are cheaper than cobalt, cathodes based on them are not yet produced in large quantities, so their current prices do not reflect the lower raw material prices. Both have significant potential for cost reduction simply because of scale economies.

The major suppliers of cathode active material are in Japan. Because volumes are low, North American material suppliers may give development of these products low priority. There is a wide range of prices $(\$ 40$ to $\$ 80 / \mathrm{kg})$. One manufacturer quoted a price of $\$ 36 / \mathrm{lb}(\$ 80 / \mathrm{kg})$ for nickel-based cathode material and $\$ 27 / \mathrm{lb}(\$ 59 / \mathrm{kg})$ for manganese-based cathode material (EM Industries 1999). Another reports that the price of manganese-based cathode material is about $25 \%$ that of cobaltbased material, in commercial quantities. This would put it at $\$ 4.50$ to $\$ 9.00 / \mathrm{lb}(\$ 10$ to $\$ 20 / \mathrm{kg}$ ). It is our judgment that cathode materials are likely to be available in the range of $\$ 10$ to $\$ 20 / \mathrm{b}$ ( $\$ 22$ to $\$ 44 / \mathrm{kg}$ ) in large volume, but prices below $\$ 10 / \mathrm{lb}(\$ 22 / \mathrm{kg}$ ) will be difficult to achieve. Pacific Lithium is hoping to produce a manganite electrode material with a price of $\$ 15 / \mathrm{kg}(\$ 7 / \mathrm{lb})$ or less (Desilvestro 2000). 
Japanese battery material producers give preferential prices to some, but not all, Japanese battery manufacturers (Ridgway 1999). Additional information comes from Toyota, which reports that the manganese-based batteries they buy from Hitachi cost a factor of 5 to 6 times less than the cobalt-based ones they were purchasing from Sony (Roque 1999). This difference cannot be explained solely on the basis of material costs.

High-power cells need a large surface area and thin electrodes, so small particle sizes are desired. High-energy cells need more material, so larger particle sizes are best for them. The thickness of material on the high-power electrodes is typically only 30 to $35 \mu \mathrm{m}$, compared with 180 to $200 \mu \mathrm{m}$ for high-energy cell electrodes. Therefore, the contribution to total cost by electrode materials is much less for high-power cells, and the costs of other components, such as separators and current collectors, are relatively more important for HEV batteries.

\subsubsection{Anode Materials}

The price of anode carbon depends on factors like grain size and morphology, which are carefully controlled. Graphite prices vary with grade; the least expensive (SFG, a synthetic graphite made by Timical), which costs about $\$ 15 / \mathrm{kg}(\$ 6.80 / \mathrm{lb})$, probably would be suitable for HEVs, or it might be necessary to pay as much as $\$ 30 / \mathrm{kg}(\$ 13.60 / \mathrm{lb})$. The most expensive graphite is MCMB (Miso-Carbon Misobine, made by Osaka Gas) at $\$ 60 / \mathrm{kg}(\$ 27.30 / \mathrm{lb})$. Typical prices range from $\$ 20$ to $\$ 40 / \mathrm{kg}$ ( $\$ 9$ to $\$ 18 / \mathrm{lb}$ ) (Spotnitz 1999b). Automotive batteries can use the cheaper carbons, and the prices would be still lower for large volumes.

Superior Graphite, based in Chicago, Illinois, produces several grades of graphite for Li-ion batteries. These grades differ in particle size, surface area, and resistance. Prices depend on customer specifications and volumes. The least expensive grade has a year 2000 price ranging from $\$ 8$ to $\$ 16 / \mathrm{kg}$ ( $\$ 3.60$ to $\$ 7.20 / \mathrm{lb}$ ), and the most expensive ranges from $\$ 30$ to $\$ 38 / \mathrm{kg}$ ( $\$ 13.60$ to $\$ 17.25 / \mathrm{lb}$ ). These prices are expected to decrease by 2003 , only slightly for the least expensive grades, but down to $\$ 22$ to $32 / \mathrm{kg}$ ( $\$ 10$ to $\$ 14.50 / \mathrm{lb}$ ) for the most expensive (Wanta 1999). Major production cost reductions associated with improved technology or economies of scale are not expected, because graphite is an established commercial product.

\subsubsection{Separators}

The polyethylene and polypropylene raw materials for separators are relatively inexpensive, with a maximum market price generally under about $\$ 1.30 / \mathrm{kg}(\$ 0.60 / \mathrm{lb})$. It is the processing that makes separators so expensive. Although it is not very capital- or labor-intensive, productivity on

a mass basis is inherently very low because the film is so thin. The prospects are good for reducing the costs somewhat for large-scale production; it is hoped that separator film could be made as cheaply as packaging film. It is possible that process modifications to allow coextrusion of the three layers could reduce manufacturing costs. New technology could potentially offer significant cost reductions. Each customer has slightly different, exacting specifications; meeting them raises processing costs. Separators currently cost from $\$ 3$ to $\$ 6$ per square meter, depending on volume, which works out to $\$ 120$ to $\$ 240 / \mathrm{kg}$ ( $\$ 54.50$ to $\$ 109 / \mathrm{lb}$ ) for material $25 \mu \mathrm{m}$ thick and with a density of $1 \mathrm{~g} / \mathrm{cm}^{3}$. The price is likely to go down to $\$ 1.25$ to $\$ 1.50 / \mathrm{m}^{2}$ (Martin 1999). An optimistic longterm goal is to bring this cost down to $\$ 1 / \mathrm{m}^{2}$, or $\$ 40 / \mathrm{kg}$ ( $\$ 18 / \mathrm{lb}$ ), with improvements on current 
processes and high-volume sales. A typical 100-A.h cell would contain separator material with an area of about $2.4 \mathrm{~m}^{2}$, so an EV would typically require about $240 \mathrm{~m}^{2}$. The entire world market is currently about 25 million square meters per year, enough for $100,000 \mathrm{EVs}$. Therefore, significant market penetration by EVs would require expansion of separator production capacity. However, the total mass of material used annually is only on the order of a million pounds, compared to polymer production measured in tens of billions of pounds in the United States alone, so polymer markets will be unaffected by separator production.

\subsubsection{Electrolyte}

The salts for use in Li-ion battery electrolytes are very expensive; one industry source (EM Industries 1999) quoted a price of $\$ 121 / \mathrm{kg}(\$ 55 / \mathrm{lb})$ for $\mathrm{LiPF}_{6}$, which represents a $50 \%$ decrease from previous price levels. This is a U.S. price for modest volumes, but it is only expected to decrease by $10-15 \%$ for larger-volume purchases. There is never likely to be production on the commodity chemical industry scale. Use of less costly materials might be possible. At $\$ 121 / \mathrm{kg}$, the salt in one kilogram of electrolyte solution costs more than $\$ 19$, and that in a $100-A \cdot h$ high-energy cell costs about $\$ 12$ ( $\$ 0.85$ for a $10-\mathrm{A} \cdot \mathrm{h}$ high-power cell). About $80 \%$ of the world's supply of electrolyte salts is produced by Hashimoto (now called Stellar). Buyers rely on the quality of the product and are reluctant to change suppliers. Although the market is controlled by one supplier, monopoly pricing is believed to inflate the price by less than $30 \%$.

Electrolyte salts are used in relatively dilute solutions, so most of the mass of the electrolyte is solvent. A 1-molar solution of $\mathrm{LiPF}_{6}$ in DEC would contain $84.3 \%$ by weight (wt\%) solvent. The solvents are generally relatively inexpensive, but the high purity required $(<12 \mathrm{ppm}$ water can be tolerated) does raise their cost somewhat. Additional costs may be incurred in obtaining mixtures of solvents. On the basis of a rough price estimate for $\mathrm{DEC}$, a typical solvent, obtained from the World Wide Web for small quantities ( $\$ 158$ for $10 \mathrm{~L}$ ) of material of $98+\%$ purity (Alfa Aesar 2000 ), the cost of materials in a liter of electrolyte is $\$ 32$, or about $\$ 28 / \mathrm{kg}(\$ 12.70 / \mathrm{lb})$. Actual prices for electrolytes, available premixed from Merck (Cincinnati), vary from $\$ 40$ to $\$ 80 / \mathrm{kg}$, with the expectation that they will drop to $\$ 20 / \mathrm{kg}$ (Spotnitz 1999b). Another new supplier of $\mathrm{LiPF}_{6}$ solutions is the Grant Chemical Division of Ferro Corporation in Zachary, Louisiana. Ferro typically purchases salts from Stellar and purifies commercial solvents, producing electrolyte solutions that sell for about $\$ 50 / \mathrm{kg}(\$ 22.70 / \mathrm{lb}$ ) (Ferro 2000 ). Lithchem, in Baltimore, Ohio, also produces electrolyte salts.

Insufficient data are available to allow realistic estimation of SPE costs. Costs for packaging of SPE cells would be reduced, and no separator would be required because the electrolyte would serve that purpose as well. However, the cost of the electrolyte itself might be so high as to cancel out these advantages. This is an interesting topic for future study.

\subsubsection{Cell Packaging and Control Circuits}

Aluminum cans are available from U.S. suppliers; those for 100-A.h cells are priced at about $\$ 10$ in very small volumes. The actual cost of the cans is considerably less, and volume prices can be estimated. For large-volume production (a fully utilized line has a capacity of 4 to 5 million smaller cans per year), one manufacturer estimated that materials accounted for $50 \%$ of the sales 
price, and about $20 \%$ of the material input ended up as scrap (Nakai 1999). If the can for the highenergy cell weighs $291 \mathrm{~g}, 364 \mathrm{~g}$ of material must be purchased, at a maximum price of $\$ 2 / \mathrm{lb}$ $(\$ 4.40 / \mathrm{kg})$. The material for one can would cost $\$ 1.60$ at most, and the high-volume can price would be under $\$ 3.20$. By the same method, the price for the high-power cell can, weighing $70 \mathrm{~g}$, would be about $\$ 0.77$. The costs for nickel-plated steel cans would be similar, with the lower unit cost of the material offset by the higher mass required. We did not estimate costs for caps, tabs, and other small parts, which contribute even less to cell costs than do the cans themselves.

It is possible that the cost of the cans could be reduced by using less material (thinner can wall). The finished cells would still be required to pass the abuse tests, however. Rigid packaging would not be required at all for SPE cells (the material would need to be tough), so packaging costs could be lowered even more.

The cost of the protection devices is relatively modest compared to the cost of the cell itself. Vents and PTC devices are very low in cost, probably on the order of pennies per cell. Melting separators are not cheap, but there is little or no cost associated with adding this useful feature to the separators, which are required for another purpose (to keep the electrodes from shorting out). The cost of the active external controllers is somewhat higher, but still relatively low compared to the cost of the cell. The individual module controllers and thermistors would probably cost $\$ 5$ to $\$ 10$ each (for an eight-cell module), and the battery pack controller would cost $\$ 20$ to $\$ 30$.

\subsection{Battery Production Costs}

The three main components of cell costs are materials, labor, and overhead. Materials costs have been discussed in detail; here, we take a brief look at labor and overhead costs, which are considerably smaller contributors to total Li-ion battery costs. These are calculated on the basis of the authors' engineering estimates of the changes required to an existing plant design, for which the costs were known, for production of larger cells. A summary of these results is presented in Table 5.1.

Table 5.1 Summary of Manufacturing Cost Components

\begin{tabular}{|lcc|}
\hline \multicolumn{1}{|c}{ Item } & High Energy & High Power \\
\hline & & \\
Plant capacity $\left(10^{6}\right.$ cells $\left./ y\right)$ & 120 & 6 \\
Workers & 30 & 140 \\
Capital investment $\left(\$ 10^{6}\right)$ & 3.50 & 35 \\
Labor cost $(\$ /$ cell) & 2.50 & 1.40 \\
Overhead cost $(\$ /$ cell) & 154.63 & 0.95 \\
Material cost $(\$ /$ cell) & 160.63 & 11.89 \\
Total manufacturing cost $(\$ /$ cell) & 96 & 14.24 \\
Materials as \% of total & & 83 \\
\hline
\end{tabular}

\subsubsection{Labor Costs}

A rough estimate of the personnel required to operate a plant that produces cylindrical cells on a balanced production line has been developed, based on expected staffing of known process steps. 
Table 5.2 provides a rough estimate of the personnel required for this production line to produce cylindrical Li-ion batteries. This estimate is consistent with the approximately 90 people employed on the production lines at a Matsushita plant making small primary lithium cells in Georgia, where capacity, investment, and other operational details are known. We made the assumption that a plant producing $\mathrm{Li}$-ion cells by similar processes would have similar costs and operational structure. The Matsushita plant, which produces 30 million $\mathrm{LiMnO}_{2}$ cells per year, represents an initial investment of $\$ 25$ million (Panasonic 1996). An analysis of this plant revealed a manufacturing cost structure on the order of $75 \%$ to $80 \%$ material, $12 \%$ to $15 \%$ labor, and about $8 \%$ overhead. The total manufacturing cost per cell is around $\$ 2$, and a battery package with two cells retails for slightly over $\$ 10$, so we are confident that these estimates are reasonable. The manufacturing costs are, of course, much higher for the larger EV cells. However, the cost increases per operation can be correlated with cell size. Some operations, such as testing, would be proportional to the number of cells, rather than their size. The capacity of this plant was reestimated on the basis of production of larger cells. Additional process units were added to keep the plant balanced (all machines $100 \%$ utilized), and the number of people needed to operate the modified plant was estimated. From the staffing and capacity estimates, we calculated the labor costs per cell shown in Table 5.1.

Table 5.2 Direct Operations Personnel for Cylindrical Cell Production

\begin{tabular}{|lc|}
\hline \multicolumn{1}{|c|}{ Item } & No. of Persons \\
\hline & \\
Operations, per line, for each shift & \\
Mixing and coating lines & 10 \\
Calendering/slitting & 3 \\
Cutting, winding, and welding tabs & 5 \\
Assembly (automated) & $3-5$ \\
Inspection & 3 \\
Testing, cycling, and packing (wholesale) & $5-10$ \\
Total plant, direct & $19-26$ \\
Total personnel (2 lines, 2 shifts) & $76-104$ \\
\hline
\end{tabular}

\subsubsection{Overhead}

To estimate the overhead cost, we used capital and other costs for the Matsushita plant because the equipment and processes used there are very similar to those for $\mathrm{Li}$-ion automotive cell production (Turner 1999). This estimate was meant to be a first approximation to see if capital and other overhead costs were a major concern for automotive cells. We calculated that the capital charges, utilities, inventory, and taxes would total $\$ 0.15 /$ cell, or about $8 \%$ of the total cell cost. We then made necessary modifications to this basic plant in order to be able to produce the larger Li-ion cells (high-energy and high-power versions). The main changes are a higher initial investment (more machines are needed) and a much lower manufacturing capacity. Using these two parameters, the overhead for a plant producing automotive cells was estimated (see Table 5.1). Capital costs and other plant overhead costs can be seen not to be a major factor for the larger lithium-ion cells, where material costs clearly dominate. 


\subsection{Total Manufacturing Costs}

To check our results, we did a rough cost estimate for the commercial 18650 cells and determined that the major materials alone make up approximately $75 \%$ of the total cell cost of about $\$ 1.70$, as can be seen in Table 5.3. Note that this estimate is consistent with actual current costs. One

Table 5.3 Rough Estimate of 18650 Cell Manufacturing Costs

\begin{tabular}{|lc|}
\hline \multicolumn{1}{|c|}{ Item } & Cost $\mathbf{( \$ )}$ \\
\hline Materials & \\
LiCoO $_{2}$ & 0.62 \\
Separator & 0.14 \\
Electrolyte & 0.30 \\
Anode & 0.24 \\
Materials subtotal & 1.28 \\
Overhead & $0.15-0.25$ \\
Direct labor & $0.18-0.24$ \\
Total manufacturing cost & $\sim 1.70$ \\
\hline
\end{tabular}

manufacturer reports that the cost of these small cells is now under $\$ 2$ each, having come down from about $\$ 18$ each in 1992 (Oweis et al. 1999) as a result of improved production processes and reduced material costs at high volume. Less dramatic cost reductions are expected as the production volumes of the larger cells grow.

Similar processes imply capital and labor costs similar to those of commercial cell production for automotive cells. Scale-up to larger-sized cells will entail more care in the coating and winding operation. A smaller number of larger cells can be produced per line, so labor and capital costs are greater per cell, but they represent a smaller percent of the total. Therefore, a similar breakdown, with even stronger dominance by the materials, is expected for the larger cells. If less expensive materials can be used, the other costs will make up a larger percentage of the total, but materials will still dominate the costs. Even if the materials costs indicated above were cut by a factor of three, they would still account for half of the total manufacturing cost. However, for the high-power cells, labor and manufacturing overhead costs would eventually become important if material costs were drastically reduced. Therefore, we postulate doubling plant productivity, by such means as increased winding speed, for our optimistic calculations of possible future battery costs.

\subsection{Purchase Price}

Thus far, we have estimated the cost to the manufacturer of producing the battery. The price paid by the consumer will be considerably higher, however, because of the additional costs that must be recovered by the battery and vehicle manufacturers and dealers. These include corporate overhead (in addition to the plant overhead included above), marketing, research, transportation, warranty costs, profit, and any other costs that are added to the manufacturing costs, plus the markup of the vehicle manufacturer. The manufacturer's markup goes toward recovering some of the vehicle manufacturing costs related to sourcing and installation of the battery (inventory, purchasing, preparation, dealer support and margin, etc.).

The level of gross margin needed by the battery manufacturer will depend to a large extent on the volume of sales. Sunk costs, such as the costs of previous research, development, and engineering, need to be recovered over the life of the product (usually 5 to 10 years), and the higher the volume, the lower the rates need to be. Typical gross margin rates for mature products of this type are on the order of $15 \%$ to $25 \%$. Advanced batteries are relatively new products, so the margins are expected to be higher, probably on the order of $35 \%$. This is the margin over manufacturing costs that will be charged by the battery manufacturer to the battery purchaser. 
The battery pack will not be sold directly to the final consumer as a stand-alone product; rather, it will be built into a complete vehicle. It is likely that the auto manufacturer will purchase the battery directly from the supplier (battery manufacturer), with no "middle men" involved. The auto manufacturer will pass on to the consumer the costs for purchasing and installing components purchased for use in the vehicle (including some general overhead). These costs plus the "dealer discount," added to cover dealer costs, make up what we call the "markup," which is added to the auto manufacturer's cost to give the manufacturer's suggested retail price (MSRP). The markup for different components of an electric vehicle was discussed in another Argonne report (Cuenca et al. 1999), where it was assumed that the electric drive components, air-conditioning drive, and batteries would be procured from outside suppliers. It was also assumed that the markup for the batteries would be lower than that for the other outsourced components at only $15 \%$ (rather than the approximately $30 \%$ usually assumed) to inhibit the development of an alternative supply channel directly from battery manufacturers to the vehicle buyer (independent of the auto maker). This low markup would require reduction of the dealer discount on that part of the EV cost due to the battery, but it would help the EV's competitive position. The conservative assumption of only a $15 \%$ markup on batteries is used in this report as well. If the batteries cannot meet their cost goals with this small markup, they certainly would not do so if the manufacturers demanded a larger return.

The combined markup from manufacturing cost is then estimated to be about $1.55(1.35 \times 1.15)$. Thus, the purchase price will be 1.55 times the sum of the material cost and the manufacturing cost. For the high-energy cell, the price (as part of a finished vehicle) will be about $\$ 250 /$ cell, and for the high-power cell, the price will be about $\$ 20 /$ cell. In the future, when the R\&D investment is recovered and plant investments have largely been paid off, the manufacturer's markup may decrease to $25 \%$, and the overall markup may decline to about $40 \%$. 
A 


\section{Section 6 Battery Cost Sensitivity Analysis}

This section provides estimates of the total costs for production of $\mathrm{Li}$-ion batteries for electric and hybrid electric vehicles and addresses how these costs could change in the future. It was stated at a recent battery symposium that material cost accounts for $75 \%$ of product cost (Bard 1998). In fact, it has been shown in Section 5 that the contribution is even greater for $\mathrm{Li}$-ion vehicle batteries, amounting to $80 \%$ or more. Therefore, the greatest potential for reducing costs lies in obtaining lower-cost materials. The emphasis is on potential cost reductions achievable either by material substitution or by developing ways to obtain the same materials at lower cost, especially for the cathode materials. On the other hand, if mass-market EV penetration occurred, supply constraints could eventually cause prices for cathode materials to rise. Sensitivity of total costs to variations in material costs is examined.

\subsection{Total Cell Material Cost}

Earlier sections of this report described the major materials in Li-ion cells, provided estimates of their current and future prices, and tabulated quantities of the materials contained. This information is put together here to estimate current costs of the materials in a cell. In the next sections, we examine how material costs could be affected by changes in the costs of the key input materials. Table 6.1 shows the approximate breakdown of current material costs for a $100-\mathrm{A} \cdot \mathrm{h}$ highenergy cell and a 10-A.h high-power cell with cobalt-based cathodes. This table is based on the material compositions in Table 2.2 and on the material costs from Section 5. Figure 6.1 shows the high-energy cell material cost breakdown graphically.

Table 6.1 Material Costs for 100-A-h High-Energy Cell and 10-A-h High-Power Cell

\begin{tabular}{|c|c|c|c|c|c|c|c|}
\hline \multirow[b]{2}{*}{ Material } & \multirow[b]{2}{*}{$\begin{array}{l}\text { Price } \\
\text { (\$/kg) }\end{array}$} & \multicolumn{3}{|c|}{ High-Energy Cell } & \multicolumn{3}{|c|}{ High-Power Cell } \\
\hline & & $\begin{array}{c}\text { Quantity } \\
\text { (g) }\end{array}$ & $\begin{array}{c}\text { Cost/cell } \\
(\$)\end{array}$ & $\%$ & $\begin{array}{c}\text { Quantity } \\
\text { (g) }\end{array}$ & $\begin{array}{c}\text { Cost/cell } \\
(\$)\end{array}$ & $\%$ \\
\hline Cathode & 55 & $1,408.6$ & 77.47 & 48.8 & 64.8 & 3.56 & 28.2 \\
\hline Separator & 180 & 60.5 & 10.89 & 6.9 & 16.4 & 2.95 & 23.3 \\
\hline Electrolyte & 60 & 618 & 37.08 & 23.4 & 44 & 2.64 & 20.9 \\
\hline Graphite & 30 & 563.6 & 16.91 & 10.7 & 12.7 & 0.38 & 3.0 \\
\hline Can and vent & & 291 & 3.20 & 2.0 & 70 & 0.77 & 6.1 \\
\hline Binder & 45 & 162.6 & 7.32 & 4.6 & 8.8 & 0.40 & 3.1 \\
\hline Copper & 15 & 151.9 & 2.28 & 1.4 & 41.6 & 0.62 & 4.9 \\
\hline Aluminum & 20 & 63 & 1.26 & 0.8 & 19.4 & 0.39 & 3.1 \\
\hline Carbon & 20 & 46.4 & 0.93 & 0.6 & 2.2 & 0.04 & 0.3 \\
\hline Other & 20 & 67.1 & 1.34 & 0.8 & 44.8 & 0.90 & 7.1 \\
\hline Total & & $3,432.7$ & 158.68 & 100.0 & 324.7 & 12.66 & 100.0 \\
\hline
\end{tabular}




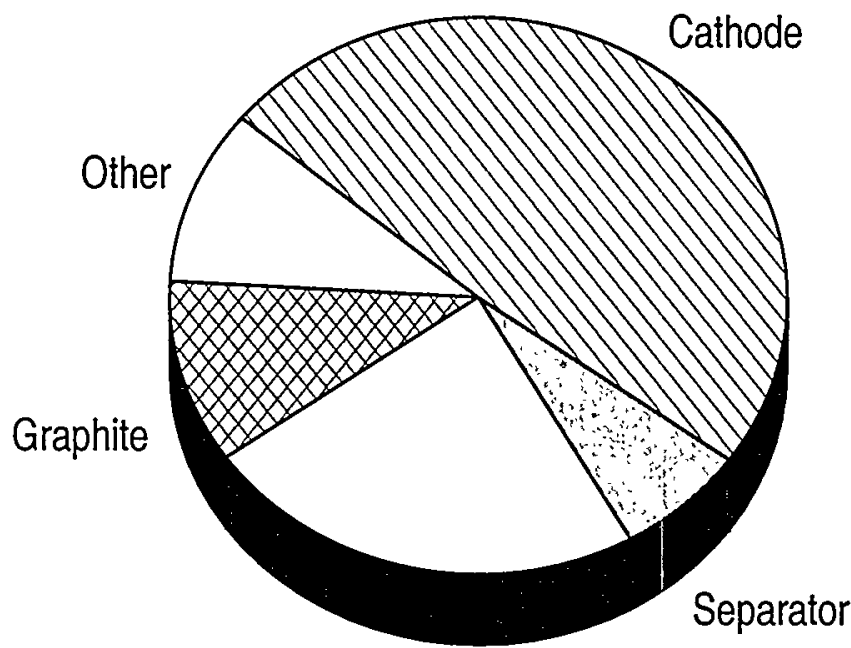

Electrolyte

Figure 6.1 High-Energy Cell Material Costs

It can be seen that the cathode contributes about half of the $\$ 159$ total material cost for the high-energy cell, more than twice as large a contribution as any other component, and almost one-third of the $\$ 12$ total material cost for the high-power cell. This difference arises because a thinner layer of cathode paste is used in the high-power cell. At $\$ 159 /$ cell, the cost of the material alone for the high-energy cell is equivalent to $\$ 436 / \mathrm{kWh}$ (with just the cathode material, $\$ 212 / \mathrm{kWh}$ ). Therefore, research efforts have been focused on the development of less expensive cathode materials. Similarly, the anode graphite's contribution decreases from $11 \%$ for the high-energy cell to 3\% for the high-power cell. The reduction in electrode thickness also causes the separator's share to rise from $7 \%$ for the high-energy cell to $25 \%$ for the high-power cell. The electrolyte makes an approximately equal and significant contribution to material costs for both cell types, at about $23 \%$.

These cost breakdowns are approximate, having been based on costs taken in the middle of a broad range of actual material prices. Actual material compositions may also vary with design details of the different manufacturers. In Table 6.2, the percentage breakdown given above for the highpower cell is compared with estimates provided by the sole U.S. manufacturer.

Table 6.2 Cost Contributions for High-Power Cell (\%)

\begin{tabular}{|lrc|}
\hline & \multicolumn{1}{c|}{$\begin{array}{c}\text { Estimated } \\
\text { Contribution }\end{array}$} \\
\cline { 2 - 3 } Component & ANL & Polystor $^{\mathrm{a}}$ \\
\hline Cathode & 30 & 25 \\
Separator & 25 & 25 \\
Anode & 5 & 19 \\
Electrolyte & 23 & 18 \\
Other & 17 & 13 \\
Total & 100 & 100 \\
& & \\
\hline
\end{tabular}

Varta does not state a total material cost, but the firm expects that the anode and cathode materials will each contribute $20 \%$ to the minimum materials cost, with the can and feedthroughs making up $38 \%$ (Brohm et al. 1998). The high contribution from the can may be associated with their use of small prismatic cells. SAFT expects that the electrolyte, separator, and cathode material will together contribute more than $60 \%$ to the material costs of their high-energy cells when they achieve their cost goal of $\$ 200 / \mathrm{kWh}$ (for production of 100,000 batteries per year) (Broussely et al. 1996).

- Spotnitz (1999a). 


\subsection{Sensitivity to Cathode Material Changes}

This section illustrates how cell costs are affected by the cost of the cathode materials. Before the recent reductions in the price of cobalt, cathode costs as high as $\$ 125 / \mathrm{kg}(\$ 57 / \mathrm{lb})$ resulted in total cell material costs of about $\$ 250$ for a $363-W \cdot h$ high-energy cell $(\$ 700 / \mathrm{kWh})$, with the cathode making up 70\% of the cell material cost. This is to be compared with the current baseline material cost of $\$ 159$ for $\$ 55 / \mathrm{kg}$ ( $\$ 25 / \mathrm{lb}$ ) cobalt-based cathode material. The material cost for the high-power cell, using $\$ 125 / \mathrm{kg}$ cathode material, would be about $\$ 17$, the cathode's share amounting to almost $50 \%$, compared to $\$ 13$ and $28 \%$ for the base case. This indicates why manufacturers have been so eager to reduce cathode costs. If the cost of cathode material could be reduced to $\$ 20 / \mathrm{kg}(\$ 9 / \mathrm{lb})$, which is half the lower-bound cost for current mixed oxides, the total costs for materials for the highenergy cell would be reduced by $31 \%$ (compared to cobalt at $\$ 55 / \mathrm{kg}$ ), to $\$ 110$, and for the highpower cell by $18 \%$, to $\$ 10.40$. The cost for cell materials for an EV like the Altra would then be about $\$ 10,500(\$ 300 / \mathrm{kWh})$, and for an HEV, about $\$ 1,040$. One PNGV battery team member (Haskins 1997) has said, "With continued development, a 40-kWh Li-ion electric vehicle battery could be produced for about $\$ 5,000$." As indicated in Figure 6.2 , this goal cannot be achieved by reductions in cathode costs alone. If there is to be hope for getting costs down even lower, the costs of other cell components must be reduced as well.

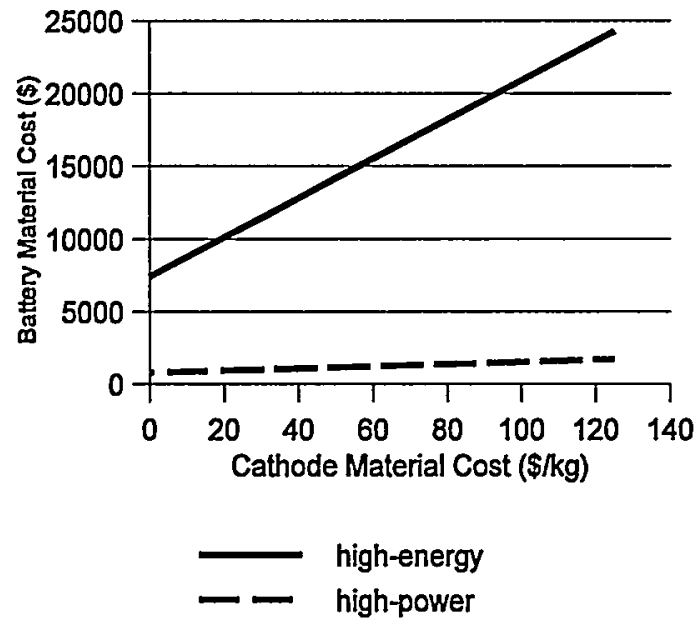

Figure 6.2 Sensitivity of Total Battery Material Cost to Cost of Cathode Material
The costs stated above are based on hypothetical price levels. The actual current costs for alternative cathode materials are shown in Table 6.3. Although the nickel and manganese prices in this table suggest that cathode material costs could eventually be reduced considerably by switching to lowercost materials, two factors will affect the potential for cost reduction. First, to achieve equivalent energy storage, various quantities of the different materials will be required. As discussed earlier, cobalt-based cells and nickelbased cells will be very similar in design, with the relative proportions of materials in the cells unchanged. However, the energy stored per cell will increase with nickel, thereby increasing the vehicle's range for the same number of cells, relative to cobalt. Alternatively, it is

possible to consider keeping the energy stored constant when the cathode is switched from cobalt to nickel, but decreasing the total number of cells and hence further reducing the cost of materials for the whole battery pack. The design configuration of a cell based on a $\mathrm{LiMn}_{2} \mathrm{O}_{4}$ cathode will be slightly different from that of one based on $\mathrm{LiNiO}_{2}$ (or a mixed oxide), the amount of material being increased to compensate for the lower practical capacity of $\mathrm{Mn}_{2} \mathrm{O}_{4}(120 \mathrm{~mA} \cdot \mathrm{h} / \mathrm{g}$ vs $200 \mathrm{~mA} \cdot \mathrm{h} / \mathrm{g}$ for 
Table 6.3 Current Cathode Material Prices

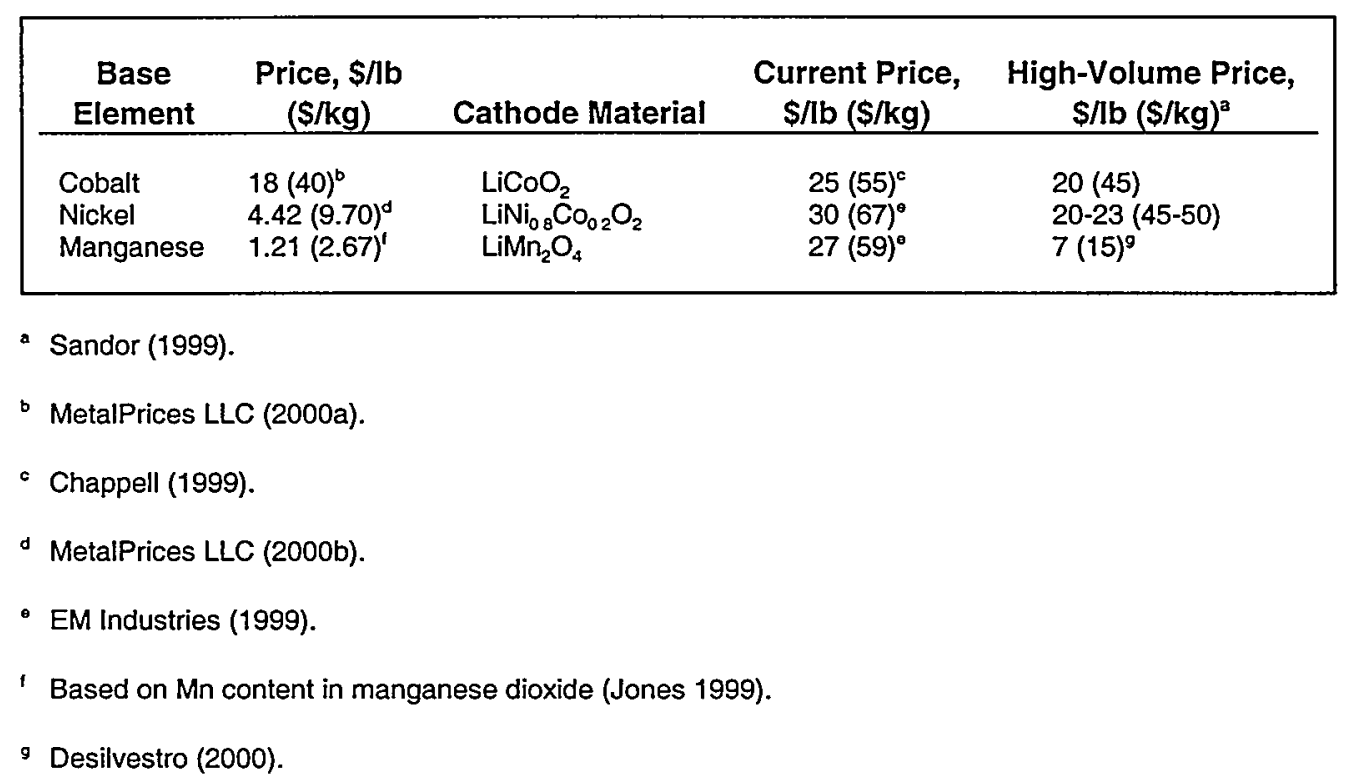

nickel). This factor will make nickel look more attractive relative to manganese than the price differential alone would suggest. Broussely et al. (1996) reported that the same cell material cost could be achieved with $\mathrm{LiNiO}_{2}$ or with $\mathrm{LiMn}_{2} \mathrm{O}_{4}$ that cost $50 \%$ as much, implying that twice as much of the manganite is required.

How do the different capacities affect the total battery material costs? If we assume that the design of the battery pack is not unchangeable, then the use of mixed oxide cathodes in place of cobalt in cells for a battery pack for an EV like the Altra could enable a reduction in the number of modules, perhaps from 12 to 9 . This would reduce the total cell material cost from $\$ 15,200$ to $\$ 8,900$, if the cobaltite were priced at $\$ 55 / \mathrm{kg}$ and the mixed oxide at $\$ 30 / \mathrm{kg}(\$ 13.60 / \mathrm{lb})$. If manganese-oxide-based cathode material were available at $\$ 15 / \mathrm{kg}(\$ 6.80 / \mathrm{lb})$, the material cost would be about $\$ 9,800$, assuming 12 modules. Less cost reduction is achieved because the required number of cells has not been decreased.

A second factor affecting cost reduction potential is limited availability of the alternative cathode materials. Currently, they are available only in extremely small quantities, so prices are both high and uncertain. Prices would presumably be considerably lower for mass quantities. Costs for both nickel- and manganese-based cathode materials could probably be brought down by at least a factor of two in large-volume production, but processing costs for the manganite might limit eventual cost reductions. One expert ventured a guess of $\$ 20 / \mathrm{kg}(\$ 9 / \mathrm{lb})$ for the eventual price of manganite in large quantities (Sandor 1999), and Pacific Lithium hopes to produce a manganite cathode material for $\$ 15 / \mathrm{kg}(\$ 7 / \mathrm{lb}$ ) or less, using a new process (Desilvestro 2000 ). However, the cobaltbased cathode material is already produced in commercial quantities, so its costs are likely to decrease the least. These factors increase nickel's promise, but there is no clear advantage, and several manufacturers, including Varta, are pursuing manganese-based cathodes. One source 
estimated a 20 to $40 \%$ material cost reduction associated with using manganite cathodes instead of cobaltite (Pacific Lithium 2000a).

\subsection{Future Material Costs and Sensitivity to Them}

The most obvious place where cheaper materials could be used or developed is in the cathode, which is the most expensive component, with development well under way. As cathode costs are reduced, other cell components make more significant contributions to material costs. Another point of potential impact is the electrolyte, which also makes a significant cost contribution. Perhaps less expensive salts could be developed. Solid polymer electrolytes could possibly reduce cell costs, especially for small cells, by obviating the need for a hard can. The cost of the raw materials for separators is trivial, but processing costs could be reduced considerably. Use of solid electrolytes could even make the use of separators unnecessary.

In Section 5, we considered how costs for several important component materials could evolve over time, either through the use of lower-cost materials or by the discovery of less costly sources or production processes for the current materials. Here, we estimate how low total material costs could be if all of the possible cost reductions were accomplished. Table 6.4 is similar to Table 6.1 (current material costs), but with extremely optimistic lower-bound material costs assumed for all of the cell components. These costs are as low as we expect costs to go with incremental improvements brought about by $R \& D$, economies of scale, etc. The cathode active material cost reduction is based on use of manganite at Pacific Lithium's projected price. Considerable reductions are possible, with the material costs for the high-energy cell potentially decreasing by over $60 \%$ and those for the high-power cell by over $55 \%$. However, even the $\$ 59$ material cost for one high-energy cell is over $\$ 160 / \mathrm{kWh}$, and this is just the material cost, not including costs for manufacturing and other tasks. Goals set for EV batteries by the USABC are shown in Table 6.5. At current material costs, Varta's high-energy Li-ion cell, which uses inexpensive manganite electrodes, still costs two times the USABC cost target (Kohler 1999). It can be seen that major breakthroughs not envisioned here, perhaps including totally different active materials or designs, would be required to meet the commercialization goal of $\$ 150 / \mathrm{kWh}$ and the long-term battery cost goal of under $\$ 100 / \mathrm{kWh}$.

Similarly, a high-power battery consisting of 10010 -A.h cells would have costs for materials alone of about $\$ 545$, well over the $\$ 300$ PNGV goal for power-assist HEV batteries. The PNGV goals for HEV batteries are shown in Table 6.6. For the power-assist application, most systems meet or are close to both the mass and volume goals. However, none of the batteries comes within a factor of two of even the mid-term cost goals, according to recent manufacturer estimates, and some are as much as a factor of six too high. Thus, it is not so much the technical performance goals that are hard to meet, but the cost goals.

Note that there are several different ways to express battery material costs, useful for different comparison purposes. Some of these are shown in Table 6.7 for current and optimistic future material costs. The high-power cells are cheaper on a mass basis than the high-energy cells, as expected, because of their reduced cathode active material use. They are also cheaper per unit of power, but costlier per unit of energy stored. 
Table 6.4 Optimistic Future Cell Material Costs for 100-A-h HighEnergy Cell and 10-A'h High-Power Cell

\begin{tabular}{|c|c|c|c|c|c|c|c|}
\hline \multirow[b]{2}{*}{ Material } & \multirow[b]{2}{*}{$\begin{array}{l}\text { Price } \\
(\$ / \mathrm{kg})\end{array}$} & \multicolumn{3}{|c|}{ High-Energy Cell } & \multicolumn{3}{|c|}{ High-Power Cell } \\
\hline & & $\begin{array}{c}\text { Quantity } \\
\text { (g) }\end{array}$ & $\begin{array}{c}\text { Cost/cell } \\
(\$)\end{array}$ & $\%$ & $\begin{array}{c}\text { Quantity } \\
\text { (g) }\end{array}$ & $\begin{array}{c}\text { Cost/cell } \\
(\$)\end{array}$ & $\%$ \\
\hline Cathode & 15 & $1,408.6$ & 21.13 & 35.6 & 64.8 & 0.97 & 17.8 \\
\hline Separator & 40 & 60.5 & 2.42 & 4.1 & 16.4 & 0.66 & 12.0 \\
\hline Electrolyte & 30 & 618 & 18.54 & 31.2 & 44 & 1.32 & 24.2 \\
\hline Graphite & 12 & 563.6 & 6.76 & 11.4 & 12.7 & 0.15 & 2.8 \\
\hline Can and vent & & 291 & 3.20 & 5.4 & 70 & 0.77 & 14.1 \\
\hline Binder & 20 & 162.6 & 3.25 & 5.5 & 8.8 & 0.18 & 3.2 \\
\hline Copper & 10 & 151.9 & 1.52 & 2.6 & 41.6 & 0.42 & 7.6 \\
\hline Aluminum & 15 & 63 & 0.95 & 1.6 & 19.4 & 0.29 & 5.3 \\
\hline Carbon & 12 & 46.4 & 0.56 & 0.9 & 2.2 & 0.03 & 0.5 \\
\hline Other & 15 & 67.1 & 1.01 & 1.7 & 44.8 & 0.67 & 12.3 \\
\hline Total & & $3,432.7$ & 59.33 & 100.0 & 324.7 & 5.45 & 100.0 \\
\hline
\end{tabular}

Table 6.5 USABC Goals

\begin{tabular}{|llccr|}
\hline \multicolumn{1}{|c}{ Criterion } & Units & $\begin{array}{c}\text { Mid-Term } \\
\text { Goals }\end{array}$ & $\begin{array}{c}\text { Commercialization } \\
\text { Goals }\end{array}$ & $\begin{array}{c}\text { Long-Term } \\
\text { Goals }\end{array}$ \\
\hline Power density & W/L & 250 & & \\
Specific power & W/kg & 150 & 460 & 600 \\
Energy density & Wh $/ \mathrm{h}$ & 135 & 300 & 400 \\
Specific energy & W.h/kg & 80 & 230 & 300 \\
Calendar life & years & 5 & 150 & 200 \\
Cycle life (DST @ 80\% DOD) & cycles & 600 & 10 & 10 \\
Sale price (25,000 units @ 40 kWh) & $\$ / \mathrm{kWh}$ & $<150$ & 1000 & 1000 \\
& & & $<150$ & $<100$ \\
\hline
\end{tabular}

Source: Cost (1999).

Table 6.6 PNGV Targets for HEV Batteries

\begin{tabular}{|llcc|}
\hline \multicolumn{1}{|c|}{ Criterion } & Units & Dual-Mode & Power-Assist \\
\hline Mass & $\mathrm{kg}$ & 65 & 40 \\
Volume & $\mathrm{L}$ & 40 & 32 \\
Available energy & $\mathrm{kWh}$ & 1.5 & 0.3 \\
Discharge pulse power & $\mathrm{kW}$ & 40 & 25 \\
Regen. pulse power & $\mathrm{kW}$ & 40 & 30 \\
Sale price & $\$ /$ battery & 500 & 300 \\
\hline
\end{tabular}

Source: Cost (1999), revised per Haskins (1999). 
Table 6.7 Materials Costs on Different Bases

\begin{tabular}{|lccccc|}
\hline & \multicolumn{2}{c}{ EV Cell } & & \multicolumn{2}{c|}{ HEV Cell } \\
\cline { 2 - 5 } \cline { 4 - 5 } Cost Basis & Current & $\begin{array}{c}\text { Optimistic } \\
\text { Future }\end{array}$ & Current & $\begin{array}{c}\text { Optimistic } \\
\text { Future }\end{array}$ \\
\hline$\$ / k W h$ & 432 & 160 & & 721 & 266 \\
$\$ / \mathrm{kW}$ & 153 & 57 & & 28 & 10 \\
$\$ / \mathrm{kg}$ & 46 & 17 & 36 & 13 \\
\hline
\end{tabular}

\subsection{Total Sales Price for the Battery Pack}

How much would a Li-ion battery pack for an EV sell for now? What are the prospects for price reduction? What would be the price of the battery for a power-assist hybrid? In this section, we estimate sales prices for $\mathrm{Li}$-ion batteries on the basis of the best current material costs and optimistic future costs. Manufacturing costs are added to material costs to approximate total cell costs. These, in turn, are multiplied by the number of cells per battery pack, and then packaging and circuitry costs are added to give total manufacturing costs. Sales price is estimated from manufacturing cost by using the method described in Section 5.4. For the optimistic case, it is assumed that R\&D and equipment investments have been recouped and the manufacturer's markup can be reduced from 1.35 to 1.25 . Actual manufacturing costs are assumed not to decrease. Table 6.8 gives estimated sales prices for a 35-kWh high-energy battery pack and a high-power battery pack composed of 100 10-A.h cells, under current best-price and optimistic future raw-material cost scenarios; these prices are compared with USABC and PNGV cost goals. It can be seen that even the optimistic prices exceed these goals. For the pure electric vehicle, this means that the battery cost is about $\$ 3,500$ over the goal, which is enough to significantly affect the marketability of the vehicle. For the hybrid, however, the total cost of the battery is much smaller, and the difference is about $\$ 800$, perhaps not enough to deter a potential buyer from purchasing the power-assist hybrid. Note that in the optimistic case for the HEV cell, labor and overhead make up $30 \%$ of the manufacturing cost, contributing an amount to the total price approximately equal to the PNGV goal. Therefore, these cost components would also need to be reduced for high-power Li-ion batteries to reach PNGV goals.

Table 6.8 Estimated Li-Ion Battery Pack Prices

\begin{tabular}{|lccc|}
\hline \multicolumn{4}{c}{ Sale Price } \\
\cline { 2 - 3 } \multicolumn{1}{c}{ Battery Type } & Baseline & Optimistic & Goal \\
\hline $\begin{array}{l}\text { High-Energy } \\
\text { (35 kWh) }\end{array}$ & $\$ 706 / \mathrm{kWh}$ & $\$ 250 / \mathrm{kWh}$ & $>\$ 150 / \mathrm{kWh}$ \\
High-Power & $(\$ 24,723)$ & $(\$ 8,767)$ & $\begin{array}{c}\text { (USABC) } \\
(100 \text { 10-A-h cells) }\end{array}$ \\
& $\$ 2,486$ & $\$ 1,095$ & $\$ 300$ (PNGV) \\
\hline
\end{tabular}


A 


\section{Section 7 \\ Recycling Considerations}

Recycling of batteries is appropriate for at least two important reasons. First, public acceptance in the United States (and government regulations in other places) will demand it, especially since the main impetus for electric vehicles is environmental. Second, there are potential economic reasons for recycling. It often pays to recover valuable materials, especially if their supply is limited, and it is costly to dispose of materials associated with potential health, environmental, or safety hazards. This does not mean, however, that all battery components should be recycled. This section examines existing recycling practices and addresses appropriate directions for the future.

\subsection{Current Status of Li-Ion Battery Recycling}

No $\mathrm{Li}$-ion automotive batteries have been recycled as yet, but Sony recycles small consumer cells, and Toxco (Trail, B.C.) recycles a variety of lithium batteries, including large military batteries; their experience is examined here. Nippon Mining and Metals is reported to have begun recycling of small $\mathrm{Li}$-ion batteries in 1997, but no details are available (England 1999). S.N.A.M. is operating a pilot plant in France (David 1999). Pacific Lithium has developed a membrane technology to recover lithium from spent batteries (Pacific Lithium 2000b).

A schematic of Sony's conception of Li-ion battery recycling is shown in Figure 7.1. The recycling process involves calcining to bake out the electrolyte (large batteries would be vented first), which renders the spent cells inactive for disassembly. The cobalt recovery makes the process economically attractive (use of less valuable cathode materials would certainly degrade the profitability, ${ }^{8}$ although the process is claimed to be economical even at reduced cobalt prices). A pilot plant in Dothan, Alabama, has a capacity of 300 tons and has so far recycled about 2 to 5 tons of small consumer cells per year. A plant in Japan has processed about 120 to 150 tons per year. The Sony recycling plants are expected to operate as for-profit businesses, without charging a drop-off fee for the spent batteries. The cobalt is (or will be) recovered in Oklahoma, at $95+\%$ purity. Sony has sought no publicity for this activity and offers no incentives for recycling; most returns are from in-warranty repairs, although there is an 800 number on the batteries, to call for recycling information. The Sony Electronics Rechargeable Battery Collection Program has been active since 1992 for all rechargeable types and includes a drop-off and direct mail system. "It is the policy of Sony Electronics, Inc., to encourage and promote environmentally sound recycling of all electronic waste." (Smith 1999; Small 1999).

8 It certainly is logical that use of a less valuable raw material will result in less valuable used materials at the end of the product's life. 


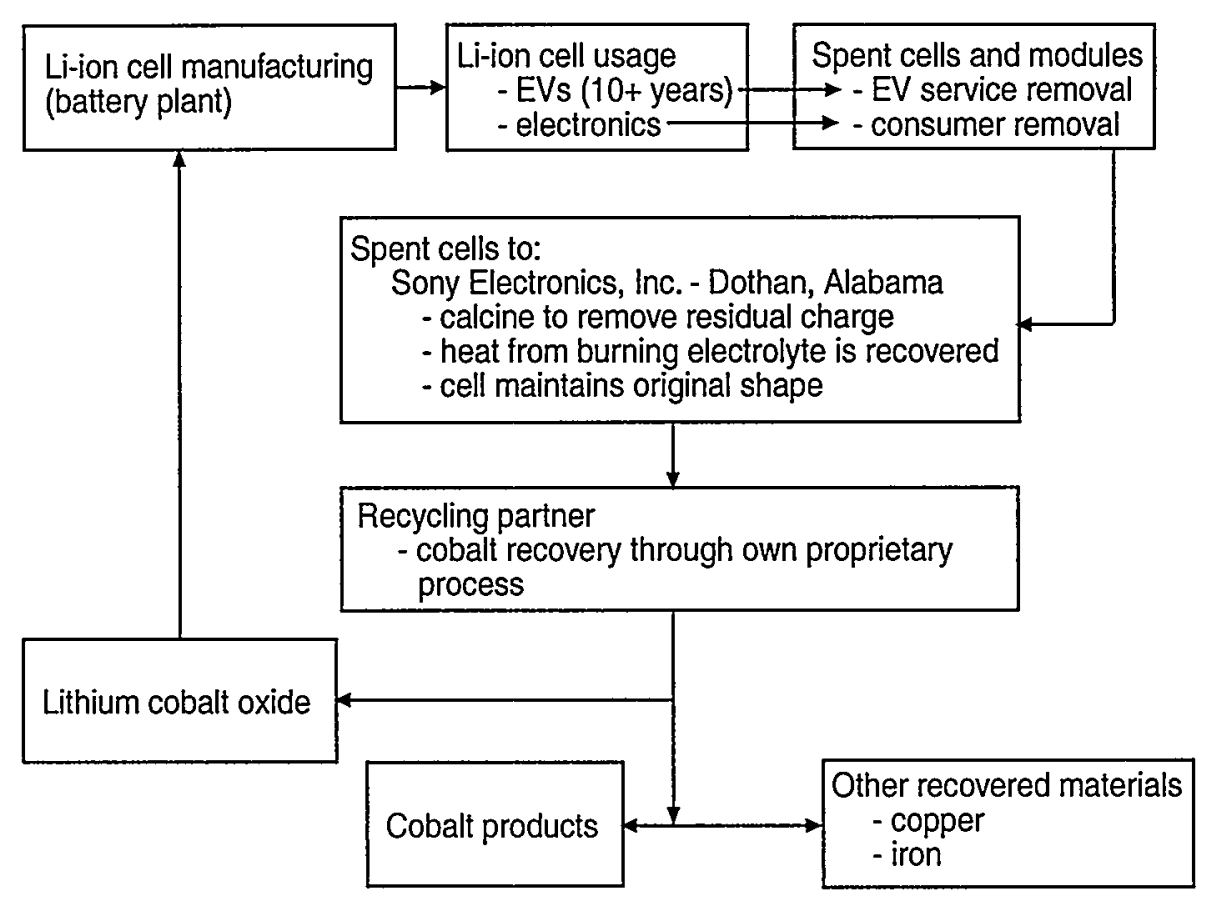

Figure 7.1 Sony Li-lon Battery Recycling Concept (Adapted from Smith 1999)

Early experiments were run in a nitrogen atmosphere. Manual disassembly was used to recover cathode strips, the most saleable product, although acid digestion or hydrometallurgical processing could also be used. The latter techniques recovered $>50 \%$ and $>70 \%$ of the cobalt, respectively. Disassembly of the NP-500 battery, which weighs $95 \mathrm{~g}$, cost $\$ 1.25$ and was found not to be economical. The value of the cobalt in the battery is only about $\$ 0.70$, and considerably less than $100 \%$ recovery is assumed. Sony hopes that disassembly costs can be reduced by a factor of 10 (Smith 1996). Larger cells might be disassembled with labor costs similar to those for small cells, but with considerably greater value in terms of recovered materials, making disassembly more viable.

Toxco, Inc., has a lithium battery recycling operation in Trail, B.C., that processed over one million pounds of batteries in 1998 . Toxco processes a variety of batteries, from buttons to $570-\mathrm{lb}$ military batteries, by using a cryogenic process to reduce the reactivity of the constituents. A schematic of the process is shown in Figure 7.2. The batteries are chilled to $-325^{\circ} \mathrm{F}$ in liquid nitrogen (see photo, Figure 7.3). Large batteries are then sheared into three pieces in a caustic bath, which neutralizes any acidic components and dissolves the lithium salts. The salts, precipitated and dewatered in filter presses, are used to produce lithium carbonate, seen being recovered in Figure 7.4. Hydrogen and organics burn off at the surface of the process bath. The sludge from $\mathrm{Li}$-ion electronics batteries is sent for recovery of cobalt. The remaining large pieces are passed through a hammer mill, after which ferrous and nonferrous metals are recovered. Plastics and paper 


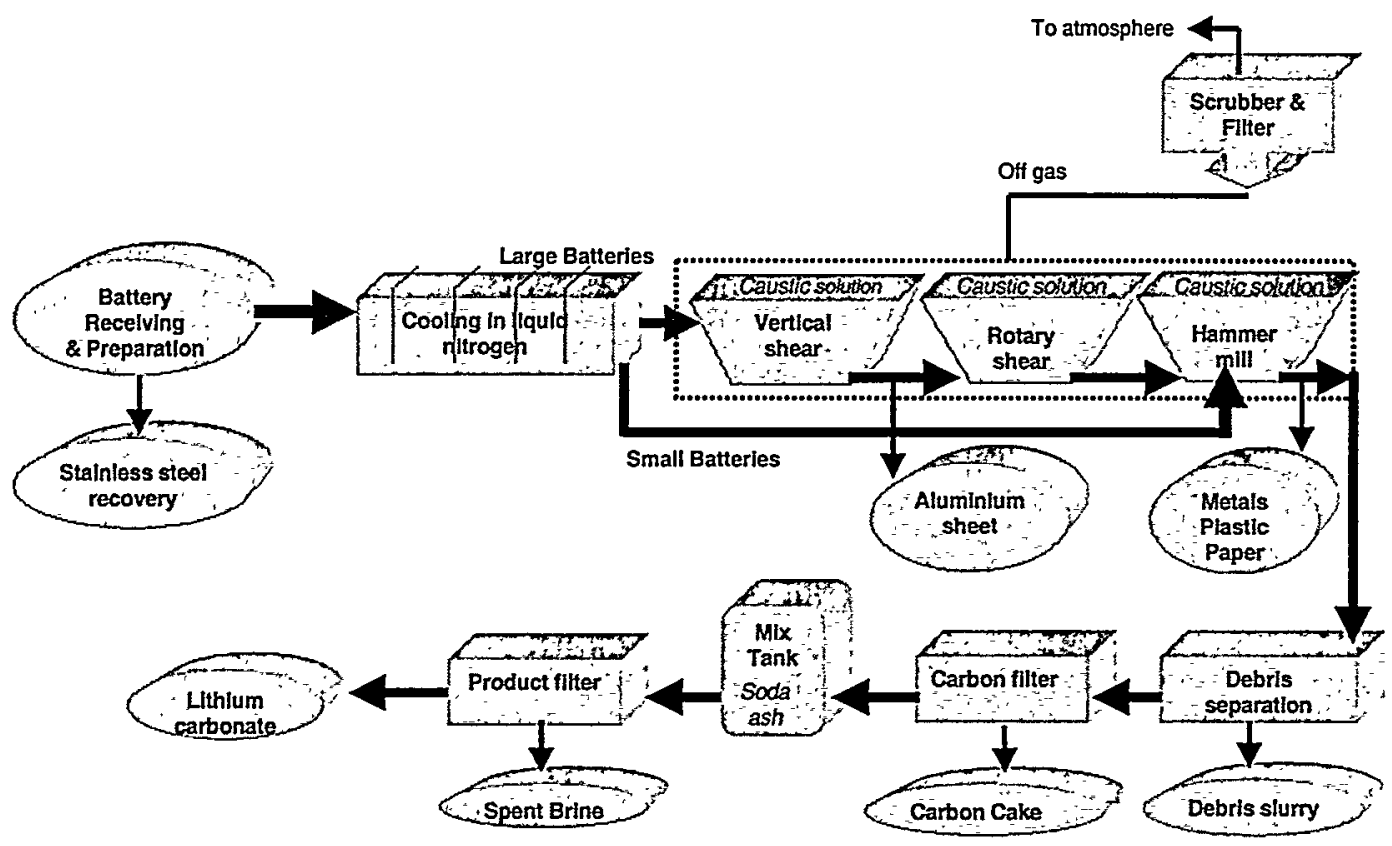

Figure 7.2 Toxco Recycling Process (Source: Toxco, Inc., 2000)

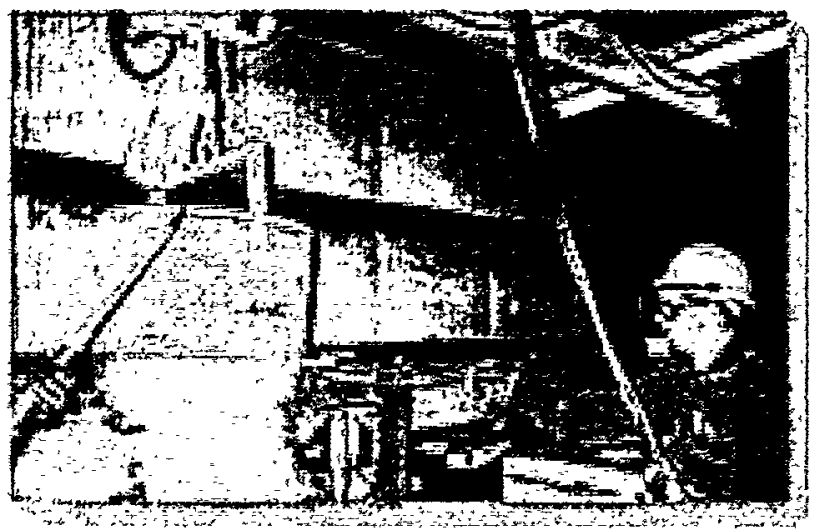

Figure 7.3 Toxco Cryogenic Freezing Process (Source: Toxco, Inc., 2000) 


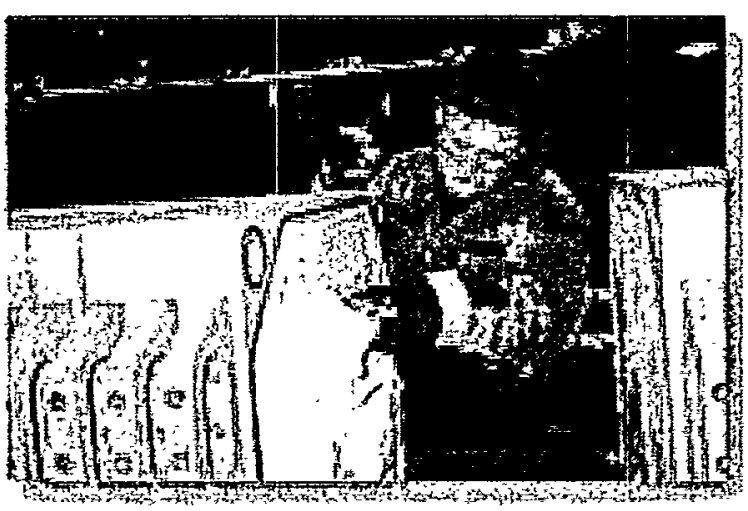

Figure 7.4 Toxco Lithium Carbonate

Recovery (Source: Toxco, Inc., 2000)

float to the top and are recovered for disposal or recycling. The carbon sludge is filtered out and collected as a cake, which it is not currently economical to reuse or even to burn. Materials are stored in bunkers and fumes are scrubbed. Different battery chemistries can be processed separately to aid in the recovery of usable materials (McLaughlin 1998; McLaughlin 1999). Toxco intends to recycle as many of the materials in the batteries as possible; recovery of the electrolyte salts would be particularly beneficial to the economics. The process is still undergoing development. Toxco's subsidiary, LithChem, makes lithium compounds for batteries in Baltimore, Ohio. LithChem produces lithium products from recovered lithium carbonate, as well as $\mathrm{LiPF}_{6}$ from $\mathrm{LiOH}$ for use in electrolytes (Miller 1999). Toxco has begun the permitting procedure for a plant in California to recycle the Li-ion batteries from Nissan's electric and hybrid vehicles, which are expected to have manganese-based cathodes.

S.N.A.M.'s $100-\mathrm{kg} / \mathrm{h}$ pilot plant first discharges and husks the battery cells, then pyrolizes them to burn off solvents and plastics. These steps account for $30-40 \%$ of the process costs. Next, the remainder is crushed and sifted, and hydrometallurgical processes are used to separate the metallic components. The process recovers steel or aluminum containers, copper and aluminum supports, cobalt and lithium hydroxides, and carbon (David 1999). It is unclear how carbon is recovered as a salable product. Note that a salable cathode product is obtained only if the material is cobalt, with a nickel content of $5 \%$ or less.

\subsection{Future Recycling Processes and Infrastructure}

Routine Li-ion battery recycling will start with electronics batteries. Only the most valuable materials (e.g., cobalt) will be recovered initially. This is somewhat of a problem because prices fluctuate. Note that the cobalt currently causes battery waste to be classed as hazardous in California. Lithium itself may be considered a hazardous waste, but EV batteries may get some relief from hazardous waste rules because they are covered by the EPA's Universal Waste Rule. Regulatory issues are discussed in more detail in an earlier report (Vimmerstedt et al. 1995). 
Recycling of large automotive batteries is much easier than recycling of small consumer cells. First of all, the collection logistics are straightforward. The current system for return of automotive batteries with each new battery purchase and stripping batteries from wrecks prior to shredding could be continued. Second, the batteries will be large enough to warrant separation by type to maximize the value of the recovered materials. Third, there is enough material in fairly large pieces to justify at least partial disassembly. The battery case, such as the PBT plastic one used in the Altra, could simply be removed for recycling or even reuse. It is also plausible to postulate removal of the cell windings from the cans to recover clean aluminum immediately. (Polypropylene cases are recovered in current lead-acid battery recycling operations; the material is ground and recycled.) Other schemes would instead shred the entire package, after discharging the cells and venting the electrolyte solvent. The solvent that is flashed off could be recovered. For safety, most processing schemes include cryogenics, inert atmospheres, or other techniques to reduce the activity of the components. One possible generic process, proposed by NREL (Vimmerstedt et al. 1995), for recovery of materials from Li-ion cells without cell venting or disassembly is shown in Figure 7.3.

It is unlikely that the separator material would be worth recovering because the quantity is very small and it could not be recovered as reusable thin, porous film. Its value as raw material would be negligible. (Polypropylene costs less than $\$ 1 / \mathrm{lb}$, but the cost of separator film exceeds $\$ 30 / \mathrm{lb}$.) Aluminum from cell casings and current collectors could be recovered easily, possibly mixed with copper. The materials of most interest are the cathode oxides and the electrolyte salts. The value of the potentially recoverable cathode materials will decrease as lower-cost materials are used, but it is expected to remain high enough to warrant recovery. NREL (Vimmerstedt et al. 1995) sketched out methods to reclaim metals by electrolytic recovery and ion exchange, but insufficient information is available to assess process viability or economics.

Lithium Technology, which has developed a membrane process to recover $\mathrm{Li}$ (as $\mathrm{LiCl}$ ) from spent batteries, claims it will be economical; at this writing, only preliminary research has been completed (Keijha 2000).

\subsection{Economics of Recycling}

The manufacturers of another battery type have a pilot program with the government of Mexico, wherein used EV batteries are placed in remote areas for storage of electricity generated by photovoltaic cells (Gifford 2000). The value for Li-ion batteries in such uses would be about that of $\mathrm{Pb}$-acid batteries, $\$ 50$ to $150 / \mathrm{kWh}$. Moreover, the batteries would still be suitable for recycling after reuse. Adding another use phase could significantly improve the lifecycle economics of EV batteries. Although Li-ion batteries might be less suitable for remote applications because of control system requirements and possibly greater environmental impacts, other second uses might be appropriate.

Recycling makes economic sense if the revenues from recovered materials plus the avoided disposal costs are greater than the costs for collection and processing. One goal of battery recycling $\mathrm{R} \& \mathrm{D}$ projects is to develop processes that are economically viable on their own. However, there may be externalities - financial or nonfinancial (e.g., air quality) costs from disposal that accrue to society as a whole or to groups other than whoever is deciding the fate of discarded items. In such cases, a governmental agency sometimes makes regulations that force recycling even when it does not make economic sense. This changes the economics by internalizing the societal cost. The added 
financial burden can be transferred from the recycler to consumers, who should be considered responsible for safe end-of-life treatment of items they have used, by such means as deposits on new batteries. Drop-off fees are not advised, because they would encourage illegal dumping. Regulations akin to those in place for $\mathrm{Pb}$-acid batteries and used engine oil would also be appropriate for encouraging returns. Auto wreckers and repair shops could also be given financial and regulatory incentives to return spent batteries for recycling. In Europe, product manufacturers are generally held responsible for end-of-life treatment; it is unclear whether this is the most efficient system for recycling.

Those recyclers that currently recycle Li-ion batteries charge fees for accepting material. These fees can be expected to decrease as the infrastructure for recycling and the markets for recycled materials are established. The consumer might pay a small fee to get rid of a battery, and then the person who collects a truckload of batteries might be paid for doing so. Sony expects its electronics battery recycling operation to be profitable with no drop-off charge, on the basis of the value of the cobalt recovered. Toxco is unsure whether automotive batteries would require a drop-off fee or if they would actually pay for the material. They currently charge to take Mn-based lithium batteries, but they might not need to do so with large volumes. This will depend on the quantity and reliability of this feedstock stream for their facilities, as well as on the recovery of other salable products (see Figure 7.4). Toxco is pondering recycling $\mathrm{LiPF}_{6}$, an expensive battery ingredient, and solvents. The LithChem salt product (not currently recovered as such from batteries) has $99.99 \%$ or better quality and is already approved (Miller 2000). Perceived quality of the recovered products is an important factor in the economics. For example, one North American battery manufacturer purchases raw materials only from Japan, in the belief that the purity is higher (Ridgway 1999). It would be necessary to persuade users of the quality of recovered products. The cost of Toxco's operation was initially about $\$ 4.50 / \mathrm{lb}(\$ 10 / \mathrm{kg})$, but it has decreased to less than half that. With larger quantities of more uniform input, costs could be expected to decrease, and revenues increase, even more.

Even if there were a high drop-off fee or a payment of $\$ 1 / \mathrm{lb}(\$ 2.20 / \mathrm{kg})$, recycling costs or revenues would not significantly perturb the lifecycle costs of Li-ion batteries. The Li-ion battery pack for a typical EV weighs approximately $800 \mathrm{lb}$. Even if the battery sales price were to come down to the USABC goal of $\$ 150 / \mathrm{kWh}$, a $30-\mathrm{kWh}$ pack would cost $\$ 4,500$, and recycling would amount to less than $20 \%$ of the initial cost. (In reality, it is expected to be even less.) 


\section{Section 8 Discussion}

\subsection{Conclusions}

It is apparent that there is significant potential for reduction in the price of $\mathrm{Li}$-ion batteries, although meeting the cost goals set for them will remain an extremely difficult task. These price reductions will be achieved by substitution of less expensive materials, as well as by utilization of improved production processes and more efficient production in larger plants. Significant R\&D will be required to achieve the reductions.

If electric vehicles were ever to be produced for the U.S. mass market, production or imports of several materials would need to be stepped up considerably, with the impact on price depending on the material. For some, such as cobalt, supplies could eventually be constrained, driving up the price. Material supply constraints would be a factor for pure EVs long before they would affect the hybrids, simply because of the larger quantities of materials required per vehicle. Similarly, hybrids would be less adversely affected in the event that battery costs remain above the goals set by the USABC and the PNGV, because batteries represent a much smaller percentage of the total cost of hybrid vehicles. Therefore, the research on material cost reduction is more crucial for EV development than for HEV development. This can be seen from the several hybrid models expected to be introduced into the automobile market during 2000 .

\subsection{Japanese Dominance of the Li-lon Battery Market}

The Japanese producers currently dominate the production of small Li-ion batteries and control much of the intermediate material supply. They have no inherent advantages, such as abundant raw material reserves (as is the case with Scandinavia's abundant hydropower for aluminum production). They do not control raw material supplies and have not developed any particularly sophisticated technology. A policy decision was made to invest large amounts of money in the required capital equipment; as a result, a production infrastructure was built and unit costs are low. American firms are somewhat risk-averse and may face higher effective costs of capital; thus, they tend to start by producing in smaller volumes. The U.S. government could conceivably counteract these factors by offering tax credits, low-interest loans, or loan guarantees. In the case of small batteries for consumer electronics, the Japanese market dominance is already established. The experience, infrastructure, and established supply lines would provide a definite advantage for Japanese producers; however, large volume production of batteries for electric and hybrid batteries has not yet been established. Therefore, this market could be somewhat more open for U.S. producers, especially if U.S. firms could develop improved materials and designs, perhaps as the result of government-supported research. 


\subsection{Possible Follow-On Work}

Several possibilities exist for useful projects to follow the work reported here. First, for the sake of comparing battery costs on a consistent basis, it is important to integrate this Li-ion cost work with the work done at the University of California at Davis on nickel-metal hydride batteries (Lipman 1999). Next, a similar cost analysis could be done on other promising new battery types, in particular lithium-polymer and lithium-ion with polymer electrolyte. These battery types might have a large potential for reducing costs if they allowed removal of the separator from the cell design.

Costs are not the only factor to be considered in choosing batteries (or in selecting areas for $\mathrm{R} \& D)$. It is also important to make sure that production of the batteries, motivated in the first place by the desire to improve the environmental footprint of automobiles, does not itself have a negative impact on the environment. To this end, it is also important to analyze the environmental impacts and energy use profile for the manufacturing of these batteries.

The most important function served by this overall economic analysis is to point out the need for continued research on materials for high-performance, long-life batteries. This effort could include extensions of Li-ion designs to new materials. Because this research is both costly and uncertain to yield results, private industry is unlikely to pursue the R\&D on its own. Therefore, it may be that increased sponsorship of this long-term, high-risk research by the U.S. government would be appropriate. Advantages of a government role include risk-sharing, reduced development time, increased U.S. competitiveness, reductions in emissions, and lessened reliance on petroleum imports. 


\section{Section 9 \\ References}

Alfa Aesar (a Johnson Matthey company), 2000 [URL http://www.alfa.com/products/prodA12477. html] (accessed May 24, 2000).

American Chemical Society, 1996, Production in the US Chemical Industry, Chemical and Engineering News, June 24. [URL http://pubs.acs.org/hotartcl/cenear/960624/prod.html]

Bard, S., 1998, "Batteries... User's Perspective," 15th International Seminar and Exhibit on Primary and Secondary Batteries, Fort Lauderdale, Fla., March 2-5.

Brohm, T., M. Maul, and E. Meissner, 1998, "Advanced Lithium-Ion Batteries for Electric Vehicles," 15th Internation] al Electric Vehicle Symposium, Oct.

Broussely, M., G. Rigobert, and G. Sarre, 1996, "Performances of a Lithium Ion Battery for Electric Vehicle," 13th International Electric Vehicle Symposium.

Carcone, J., 1998, "Update on Li-Ion Batteries," 15th International Seminar and Exhibit on Primary and Secondary Batteries, Fort Lauderdale, Fla., March 2-5.

Chappell, H., 1999, Sogem, USA, Raleigh, N.C., personal communication, Sept.

Cost, H., 1999, "Status of USABC/PNGV Battery Development," 11th International Battery Waste Management Seminar, Deerfield Beach, Fla., Nov. 1-3.

Cuenca, R.M., L.L Gaines, and A.D. Vyas, 1999, Evaluation of Electric Vehicle Production and Operating Costs, Argonne National Laboratory Report ANL/ESD-41, Aug.

David, J., 1999, Battery Recycling '99, 11th International Battery Waste Management Seminar, Deerfield Beach, Fla., Nov. 1-3.

Desilvestro, H., 2000, Pacific Lithium, New Zealand, personal communication, Feb.

EM Industries (Division of Merck, Inc.), 1999, Hawthorne, N.Y., personal communication, Sept.

England, N., 1999, PRBA Global Update, $11^{\text {th }}$ International Battery Waste Management Seminar, Deerfield Beach, Fla., Nov. 1-3.

Ferro, Inc., 2000, personal communication, March 6-9.

Gifford, P., 2000, Reuse of Nickel Metal Hydride Batteries in Remote Areas, Advanced Battery Readiness Ad Hoc Working Group, Washington, D.C., March 22-23. 


\section{$\Delta$}

Hake, M., 1996, Rechargeable Lithium Batteries: Li-Ion Technology, Varta Special Report 1/96, Oct.

Haskins, H., 1999, Ford Motor Company, Dearborn, Mich., personal communication, Dec.

Haskins, H., 1997, "Lithium Ion Battery Technology Shows Promise," USCAR web site [URL http://www.pm.branch.com/lithium.html] (as of June 3, 1997).

Hoffman, D., 1999, Celgard, Charlotte, N.C., personal communication, Nov.

Hohsen Corp., 1998, Osaka, Japan; advertisements in ITE Battery Newsletter, No. 2 (March-April), published by International Technology Exchange Society, ITE-JEC Press, Inc., Brunswick, Ohio.

Irving, I., 1998, "Overview of Li-Ion Polymer Rechargeable Batteries," Wireless Design Online, Oct. 29. [URL http://news.wireless.design...e.com/design_features/1998_1029_1314.html] (accessed Sept. 27, 1999).

Jones, T.S., 1999, USGS, Reston, Va., personal communication, Dec.

Kalhammer, F.R., et al., 1995, Performance and Availability of Batteries for Electric Vehicles: A Report of the Battery Technical Advisory Panel, prepared for California Air Resources Board, El Monte, Calif., Dec. 11.

Keijha, J., 2000, HPS-High Purity Lithium from Spent Lithium Battery Materials, Advanced Battery Readiness Ad Hoc Working Group, Washington, D.C., March 22-23.

Koch, V., 2000, "Advanced Materials for High Power Li-Ion Batteries," $17^{\text {th }}$ International Seminar and Exhibit on Primary and Secondary Batteries, Ft. Lauderdale, Fla., March 6-9.

Kohler, U., 1999, VARTA Status on Advanced Batteries, Advanced Battery Readiness Ad Hoc Working Group Meeting, Washington, D.C., Feb. 18-19.

Kuck, P., 2000, Recycling of Ni-Bearing Scrap, Advanced Battery Readiness Ad Hoc Working Group, Washington, D.C., March 22-23.

Kuck, P., 1999, USGS, personal communication, Dec.

Kuck, P., 1996, Nickel, USGS, Minerals Information.

Lipman, T.E., 1999, The Cost of Manufacturing Electric Vehicle Batteries, Report for the California Air Resources Board, Institute for Transportation Studies, University of California, Davis, Calif., Report Number UCD-ITS-RR-99-5, May.

Martin, T., 1999, Celgard, Charlotte, N.C., personal communication, Nov. 
McLaughlin, W., 1999, Summary of Lithium Battery Recycling Status, Advanced Battery Readiness Ad Hoc Working Group Meeting, Washington, D.C., Feb. 18-19.

McLaughlin, W., 1998, Recycling of Large Lithium Batteries, Advanced Battery Readiness Ad Hoc Working Group Meeting, Washington, D.C., March 4-5.

MetalPrices LLC, 2000a [URL http://www.MetalPrices.com/metals/co/co_12_month_charts.htm] (accessed April 20, 2000).

MetalPrices LLC, 2000b [URL http://www.metalprices.com/metals/nickelalloys/ni_chart_12_ month_price.htm] (accessed May 15, 2000).

Miller, D., 2000, EV Battery Recycling, Advanced Battery Readiness Ad Hoc Working Group, Washington, D.C., March 22-23.

Miller, D., 1999, Toxco, Trail, B.C., Canada, personal communication, Nov.

Miyamoto, T., E. Oohami, T. Horiba, et al., 2000, "Development of a Lithium-Ion Battery System for HEVs," SAE 2000-01-1057, 2000 World Congress, Detroit, Mich., March 6-9.

Nakai, M., 1999, Matsushita Battery Industrial Corp. of America-Materials Division (MBIA-MD), Columbus, Ga., personal communication, Nov.

Narang, S., 1998, "Nonflammable Electrolyte for Lithium Batteries," 15th International Seminar and Exhibit on Primary and Secondary Batteries, Fort Lauderdale, Fla., March 2-5.

Nissan, 1999 [URL http://www.nissan-na.com/1.0/1-2-le.html] (as of Jan. 14, 1999).

Ober, J., 1999, USGS, personal communication, Nov.

Ober, J., 2000, Lithium Market/Supply News, Advanced Battery Readiness Ad Hoc Working Group, Washington, D.C., March 22-23.

Oweis, S., 1999, Li-Ion Battery Technology at SAFT, Advanced Battery Readiness Ad Hoc Working Group Meeting, Washington, D.C., Feb. 18-19.

Oweis, S., et al., 1999, "Lithium Ion Technology for Hybrid Electric Vehicles," Energy Storage Technology Conf., University of California at Davis, April 27.

Pacific Lithium, 2000a [URL http://www.pacificlithium.com/p1 10.htm] (accessed Feb. 2, 2000).

Pacific Lithium, 2000b [URL http://www.pacificlithium.com/purif.htm] (accessed Feb. 2, 2000).

Panasonic Corp., 1996, "Matsushita Celebrates Official Opening of Lithium Battery Plant in Columbus, Georgia," press release, May 10. 
Paul Scherrer Institute web site, 2000, Villigen, Switzerland [URL: http://www1. psi.ch/www_f5_hn/Electrochemistry/lithium.html] (accessed March 20, 2000).

Pekala, R.W., et al., 2000, "Separators: An Overlooked Opportunity to Enhance Battery Performance?," 17th International Seminar and Exhibit on Primary and Secondary Batteries, Ft. Lauderdale, Fla., March 6-9.

Piazza, S., 1998, "Lithium Ion Polymer Batteries," 15th International Seminar and Exhibit on Primary and Secondary Batteries, Fort Lauderdale, Fla., March 2-5.

Pickering, P., 2000, Pacific Lithium, Auckland, New Zealand, personal communication, March.

Polystor Corp., Inc., 2000 [URL http://www.polystor.com/manuf.htm] (accessed May 24, 2000).

Ridgway, M., 1999, NEC Moli Energy, Maple Ridge, B.C., Canada, personal communication, Nov.

Roque, G., 1998, General Update on Lithium Ion Batteries with the Altra EV, Advanced Battery Readiness Ad Hoc Working Group Meeting, Washington, D.C., March 4-5.

Roque, G., 1999, Nissan Motor Corporation USA, personal communication, Nov.

Roque, G., and W. McLaughlin, 1999, "Preparing for the EVs and the EV Batteries," 11th International Battery Waste Management Seminar, Deerfield Beach, Fla., Nov. 1-3.

Sandi, G., 1999, Argonne National Laboratory, Argonne, Ill., personal communication, Oct.

Sandor, G., 1999, FMC Corp. Lithium Division, Gastonia, N.C., personal communication, Sept.

Scrosati, B., 2000, "New Lithium Ion Battery Materials," 17th International Seminar and Exhibit on Primary and Secondary Batteries, Ft. Lauderdale, Fla, March 6-9.

Shedd, K., 1999, USGS, Reston, Va., personal communication, Dec.

Small, M., 1999, "Update on Sony Li Ion Battery Recycling Programs," 11 th International Battery Waste Management Seminar, Deerfield Beach, Fla., Nov. 1-3.

Smith, D., 1996, Sony Lithium-Ion Battery Recycling Program, Advanced Battery Readiness Ad Hoc Working Group Meeting, Washington, D.C., March 21-22.

Smith, D., 1999, Lithium-Ion Battery Recycling, Advanced Battery Readiness Ad Hoc Working Group Meeting, Washington, D.C., Feb. 18-19.

Sony, 2000 [URL http://www.world.sony.com/Electronics/BAT/ION/eng/page1.html] (accessed May 10, 2000). 
Spotnitz, R., 1999a, Lithium-Ion Batteries for Hybrid Electric Vehicles, Ad Hoc Working Group Meeting, Washington, D.C., Feb. 18-19.

Spotnitz, R., 1999b, Polystor Corp., Dublin, Calif., personal communication, March.

Toxco, Inc., 2000 [URL http://www.toxco.com/Pages/Fac.html] (accessed May 24, 2000).

Turner, R., 1999, Matsushita Battery Industrial Corp., Columbus, Ga., personal communication, Jan.

U.S. Geological Survey, 2000, "Mineral Commodity Summaries," from web site [URL http://minerals.usgs.gov/minerals/pubs/mcs/] (as of Feb. 2000).

U.S. Geological Survey, 1998, "Metal Prices in the United States through 1998," from web site [URL http://minerals.usgs.gov/minerals/pubs/metal_prices/] (accessed May 10, 2000).

U.S. Geological Survey, 1997, “Minerals Information - 1997," reports for Lithium, Cobalt, Nickel, and Manganese, from web site [URL http://minerals.usgs.gov/minerals/pubs/mcs/1997/].

Vimmerstedt, L.J., S. Ring, and C.J. Hammel, 1995, Current Status of Environmental, Health, and Safety Issues of Lithium Ion Electric Vehicle Batteries, National Renewable Energy Laboratory Report NREL/TP-463-7673, Sept.

Wanta, M., 1999, Superior Graphite, Chicago, Ill., personal communication, Nov. 25.

Xie, L., D. Fouchard, and S. Megahed, 1995, "Material Requirements for Lithium-Ion Batteries," Material Research Society Symposium Proceedings, Vol. 393. 


\section{Distribution}

\section{Internal}

F. Bennett

R.M. Cuenca

L.L. Gaines (208)

G. Griparis
M. Hale

L.R. Johnson

R.P. Larsen

D.J. Santini

\section{External}

ANL-E Library

ANL-W Library

K. Heitner, U.S. Department of Energy, Office of Transportation Technologies (25)

P.D. Patterson, U.S. Department of Energy, Office of Transportation Technologies (10)

R. Sutula, U.S. Department of Energy, Office of Transportation Technologies (10)

U.S. Department of Energy, Office of Scientific and Technical Information (2) 